\title{
SJD Dissertation: A Libertarian Framework for Indian Rights
}

TORIVIO A. FODDER

\section{ABSTRACT}

The following document contains my research and SJD Dissertation, as submitted during the 2011 - 2012 Academic year. 


\section{TABLE OF CONTENTS}

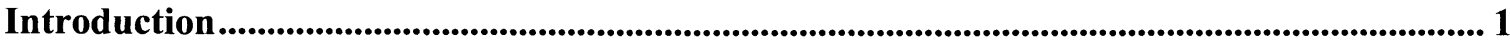

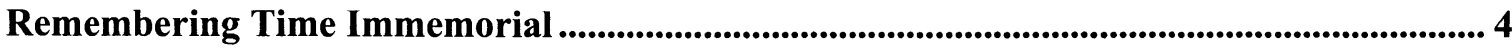

Federal Indian Law and The Destruction of Tribal Institutions..............................................9

A. Three Pillars of Modern Federal Indian Law ............................................................9

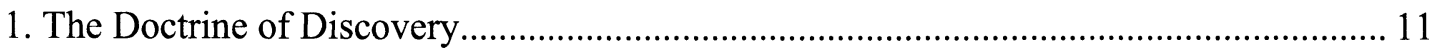

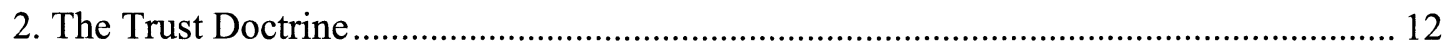

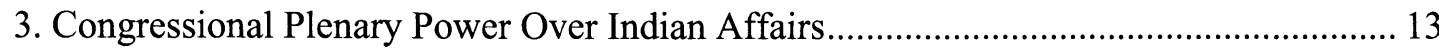

B. Modern Federal Indian Law: The Marshall Model Legacy ............................................ 14

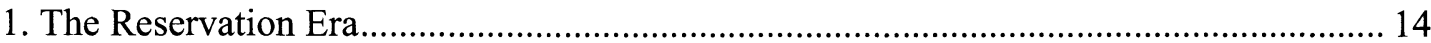

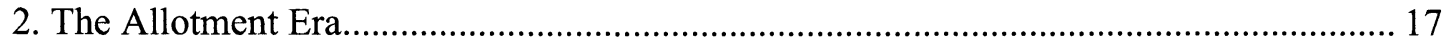

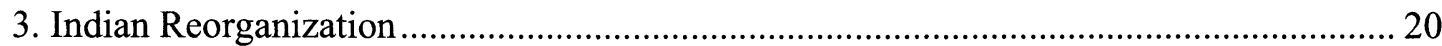

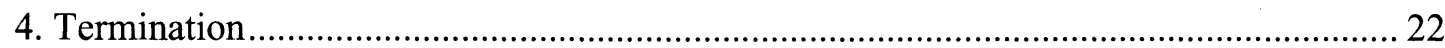

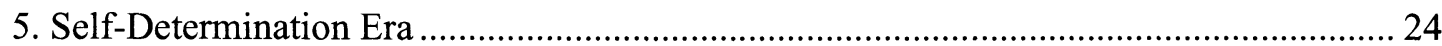

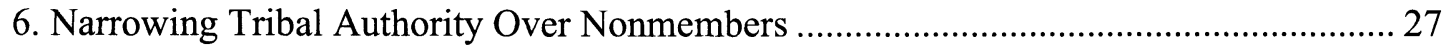

C. Critical Perspectives of Federal Indian Law ................................................................ 31

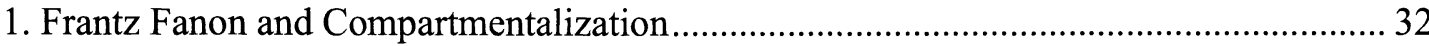

2. Michel Foucault and the Power of Malleable Rules......................................................... 35

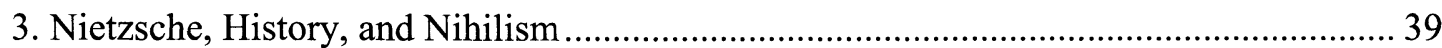

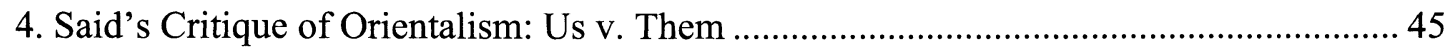

5. Antonio Gramsci on Hegemony and Intellectuals ....................................................... 49

6. Robert Williams on Confronting the Powers That Be …............................................. 52 


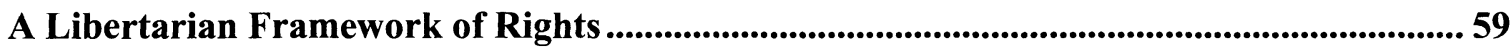

A. What Is Libertarianism? ........................................................................................................ 61

B. The Role of Government Within a Libertarian Framework ......................................... 63

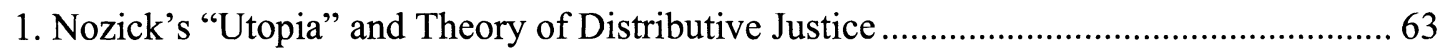

2. The Influence of Bastiat on the Metes and Bounds of Government............................... 68

C. The Role of Freedom in Securing Rights ................................................................... 71

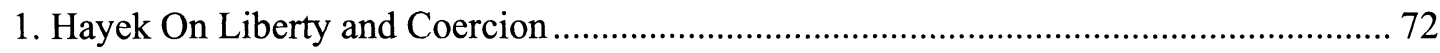

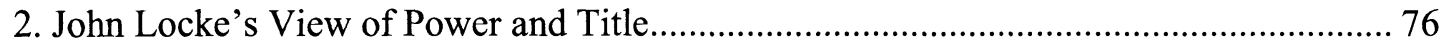

3. Popper's Defense of the Open Society and a Critique of Nationalism........................... 79

D. The Role of the Market in Preserving Freedom........................................................ 83

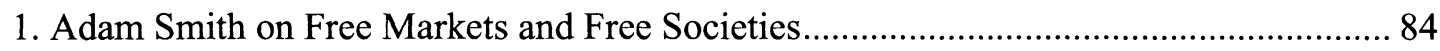

2. Milton Friedman on the Weapon of Choice, and Voluntary Exchange........................... 88

3. Thomas Sowell on the Importance of Property Rights for Law and Order ..................... 94

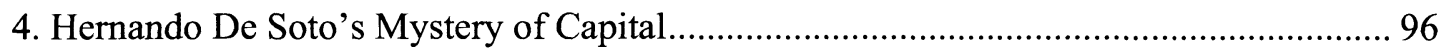

5. Ayn Rand on the Importance of Freedom and Creative Capacity ................................. 99

Critiques of Libertarianism ............................................................................................................ 103

A. What's the Role of Government in Society? ......................................................... 103

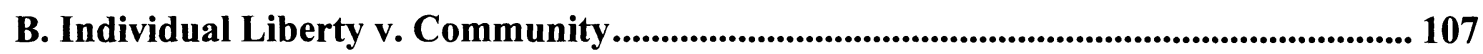

C. Economic Critiques................................................................................................................................. 110

A Libertarian Framework for Indian Rights........................................................................ 115

1. A Brief Response to the Communitarian Critiques ................................................... 115

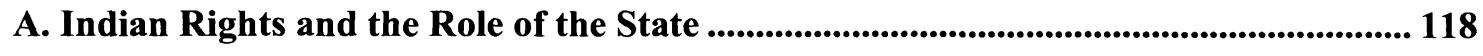

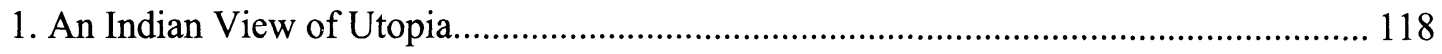




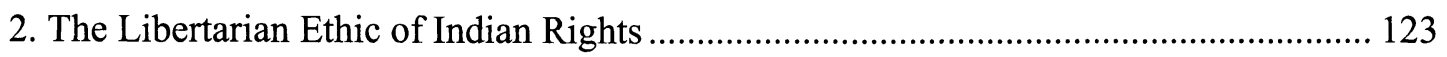

B. The Role of Freedom in Securing Indian Rights ....................................................... 125

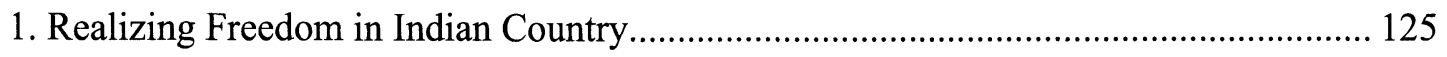

2. Indian Rights, Locke, and a Surprising Defense of Native Title ................................. 128

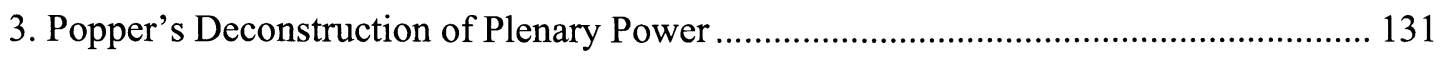

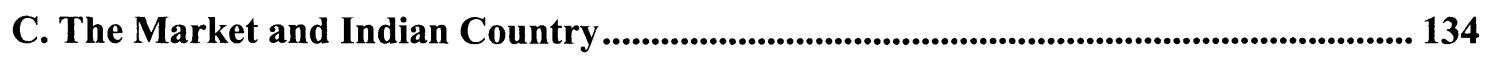

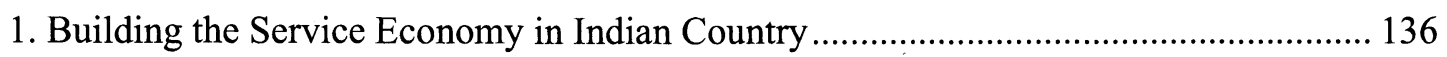

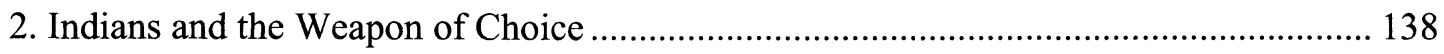

3. Developing Meaningful Indian Property Rights...................................................... 142

4. Reviving the Reservation: De Soto on Dead Capital................................................... 145

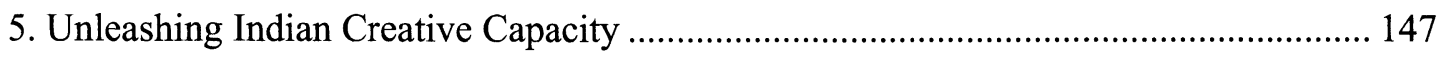

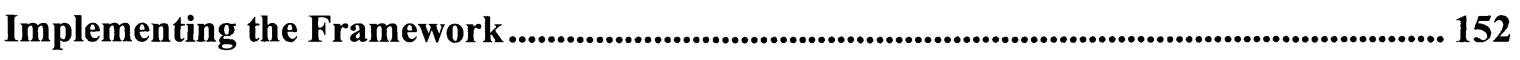

A. Summarizing of the Libertarian framework for Indian rights ................................ 153

B. Re-envisioning the Government-to-Government Relationship....................................... 158

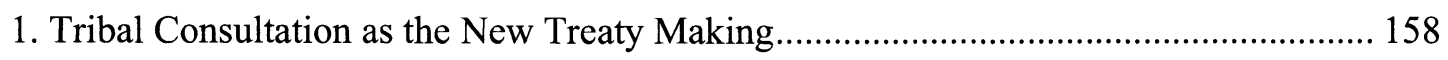

2. Measured Separatism and Meaningful Self-Determination....................................... 160

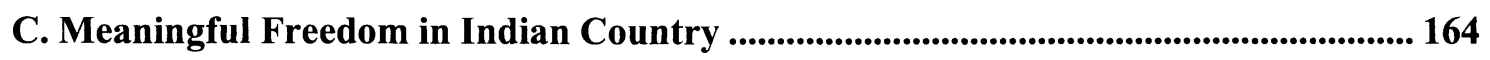

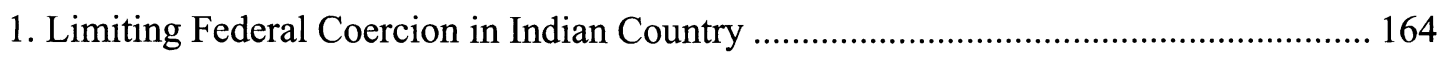

2. Questioning Federal Plenary Power....................................................................... 167

D. Unleashing the Market in Indian Country ................................................................ 170

1. Developing an Indian Service-Based Economy …............................................. 170

2. Meaningful Property Rights in Indian Country ...................................................... 173

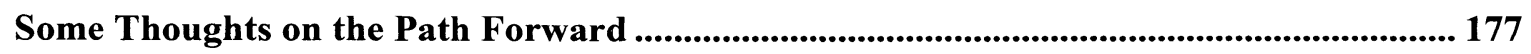


Introduction

\section{INTRODUCTION}

There was a house made of dawn. It was made of pollen and of rain, and the land was very old and everlasting.

-N. Scott Momaday

State Highway 68 winds its way through the craggy terrain of northern New Mexico, hugging the Rio Grande River on one side, and the ancient escarpments of canyon wall on the other. The road ends unceremoniously in the middle of Taos, NM, less than a block away from its historic plaza, art galleries, and restaurants. The town's popularity was rekindled by the New York Times' Travel Section in a Henry Shunkman piece titled, “D.H. Lawrence's New Mexico: The Ghosts That Grip the Soul of Bohemian Taos." Though the essay waxes eloquent about author D.H. Lawrence, and "the American modernists who clustered in Taos,"” it remains silent as to the area's original inhabits, residing in Taos Pueblo only three miles away from the city's presumptively "Bohemian" soul.

At risk of reading too much into a New York Times' travel essay, the disconnect between the City of Taos and the Taos Pueblo typifies much of the misunderstanding between modern American culture and Native peoples generally. The analogy is not a perfect one but Taos and Taos Pueblo stand sentry opposite one another, the former guarding over an era of unprecedented

\footnotetext{
${ }^{1}$ Henry Shunkman, D.H. Lawrence's New Mexico: The Ghosts That Grip the Soul of Bohemian Taos, N.Y. Times TR9, http://travel2.nytimes.com/2006/10/22/travel/22culture.html, (Oct. 22, 2006).

${ }^{2}$ Id.
} 
"global economic interdependence" ${ }^{" 3}$ and the latter desperately seeking to protect sacred places, perhaps known only to the members of the Pueblo. ${ }^{4}$

This clash of values was not necessarily an inevitable one. Centuries of misguided policy wrought by the U.S. Government and the U.S. Supreme Court have played a critical role in the systemic and systematic destruction of tribal institutions. As Indians struggled to adapt to the forces of acculturation, neither the private, nor public spheres of tribal life were spared. As a result, America's tribal nations find themselves in states of reliance upon the U.S. Federal Government both for the recognition of their own sovereignty, and in many instances the micromanagement of their tribal fiscal and social policies as well..$^{5}$ To frame the situation of Indian Country in terms of the market, no peoples are so heavily regulated as today's American Indians. ${ }^{6}$ Naturally, no peoples' economic development has been more hindered.

The purpose of this dissertation is to outline a vision for change in Indian Country, drawing from the fields of libertarian political philosophy, and critical race legal theory en route to developing a new legal framework of Federal Indian policy derived from elements of both. The goal is to arrive at a Federal Indian policy that reflects a more efficient, liberty-maximizing policy that allows for a true realization of tribal self-determination. Naturally, this thesis will take time to develop, but the general outline will proceed in five parts:

1) Chapter one will provide a brief overview of the situation of America's Indian tribes at the time of contact, analyzing both the public and private spheres of tribal life.

\footnotetext{
${ }^{3}$ Thomas Sowell, Basic Economics, at 551 (4th ed., Basic Books 2011).

${ }^{4}$ John W. Ragsdale, Jr., Possession: An Essay on Values Necessary for the Preservation of Wild Lands and Traditional Tribal Cultures, 40 Urb. Law. 903, at 946 (2008).

${ }^{5}$ Stephen Cornell, Remaking the Tools of Governance: Colonial Legacies, Indigenous Solutions in Rebuilding Native Nations: Strategies for Governance and Development, 57, 60-64 (Miriam Jorgensen ed., U. Ariz. Press 2007).

${ }^{6}$ Katherine J. Wise, A Matter of Trust: The Elimination of Federally Funded Legal Services on the Navajo Nation, 21 Am. Indian L. Rev. 157, 168 (1996).
} 
2) Chapter two examines the basic principles of modern Federal Indian Law, and demonstrates how early tribal institutions were systematically destroyed by the Federal Indian law framework using the deconstructive tools of Critical Race Theory.

3) Chapter three explores libertarian political philosophy and its scholarly pedigree in order to glean a new perspective on rights that reconsiders the appropriate function of government, the importance of freedom, and the role of markets in society.

4) Chapter four explores scholarly criticisms of libertarian philosophy, drawing from the tradition of communitarian philosophy.

5) Chapter five addresses the communitarian critiques of libertarian philosophy, and then develops the key elements of libertarian philosophy necessary to construct a new framework for Indian rights that reflects a goal of tribal self-determination through measured separatism, ${ }^{7}$ while also maximizing the liberty interests of American Indians.

6) Chapter six explores what a pragmatic implementation of the libertarian framework for Indian rights might look like, and applies the principles of the framework to some of Indian Country's key legal and policy issues.

\footnotetext{
${ }^{7}$ See Robert A. Williams, Like a Loaded Weapon: The Rehnquist Court, Indian Rights, and the Legal History of Racism in America, xxxv (U. Minn. Press 2005).
} 


\section{CHAPTER 1}

\section{REMEMBERING TIME IMMEMORIAL}

Reconstructing the situation of American Indians prior to contact with European powers is a tightrope walk along the line of history and interpretation. It is an act fraught with overgeneralization. ${ }^{8}$ Still, the goal of recalling these historic, tribal governments is not to obtain a comprehensive understanding of the nuances of American Indians at the time Europeans arrived. Better scholars have already spilt much ink on this topic, and there is no guarantee that our understanding of tribal governments would necessarily lead us to a different policy template than the one already foisted upon tribes by the Federal Government. As philosopher Karl Popper wrote in his ruminations on history and meaning, "all statements about specific causal connections retain the same hypothetical character. We can never be certain...that A is the cause of $\mathrm{B}$, precisely because we can never be certain whether the universal hypothesis in question is true, however well it may be tested." Popper's point as applied to this particular study is simply that a more erudite understanding of tribal governments at the time of contact would not inevitably lead to a different policy outcome, or, indeed, even the same policy outcome

\footnotetext{
${ }^{8}$ David H. Getches, Charles F. Wilkinson, Robert A. Williams, Cases and Materials on Federal Indian Law 5th Ed., 9 (West 2005).

${ }^{9}$ Karl R. Popper, Has History Any meaning in The Open Society and Its Enemies, Vol. 2, 259, 363 (Princeton U. Press 1966).
} 
experienced by tribes today. The best history can offer us is a set of assumptions that we are left to interpret how we will.

However incomplete or subjective our understanding of the situation of tribal governments at the time of contact may be, reviewing this history is, nonetheless, crucial for interpreting how these institutions were destroyed. Naturally, this interpretation itself is a necessary precursor before exploring new ways to formulate a Federal Indian policy that maximizes the liberty interests of tribes, and allowing for an actualization of tribal sovereignty in the process. Fortunately, this question of tribal governments - both contemporary, and historical - has a rich, scholarly pedigree. The Harvard Project on American Indian Economic Development in partnership with the Native Nations Institute for Leadership, Management, and Policy at the University of Arizona, has produced some of the most profound research devoted to building strong tribal nations. The balance of these collaborations has focused on assessing the state of America's Indian tribes, and the institutions that allow tribal governments to flourish.

In their latest treatise The State of the Native Nations, the Harvard Project recounts the "heterogeneous" history of tribal governments in the United States prior to contact, describing them along a continuum of governmental structures ranging from the "relatively informal" to the "highly differentiated," complete with lines of succession, and systems of checks and balances. ${ }^{10}$ As noted above, this sheer variety among tribes and their governmental structures makes generalization, in a sense, inevitable. But the important point of note from the Harvard Project assessment is that tribes at the time of contact did not exist in a state of anarchy, but were organized into coherent governmental structures specific to their tribal customs and way of life. ${ }^{11}$

\footnotetext{
${ }^{10}$ Harvard Project on American Indian Economic Development, The State of Native Nations, 18 (Oxford U. Press 2008).

${ }^{11}$ Id.
} 
In an important article discussing the vestiges of colonization imbued within the practice of federal and state taxation of tribal governments, the University of Idaho's Angelique EagleWoman explores the "salient characteristics [of government] for the majority of these nations." 12 Prof. EagleWoman notes that pre-contact tribal governments were very much related to the "social, spiritual, intellectual, and economic" values of the various tribal communities they served. ${ }^{13}$ This suggests a number of important distinctions between pre-contact, tribal notions of government, and governments as they have been conceptualized today. First, pre-contact, tribal institutions were rather unlike the bloated bureaucracies we have come to associate with most governmental structures here in the U.S. Rather than managing massive cabinet departments, and agencies, tribal governments were inherently local governments, designed to promote "relationship" in a community, and aimed at strengthening "family structures within a worldview of spiritual connectedness." ${ }^{\prime 14}$ Former House Speaker Tip O’Neil may have coined the phrase "all politics is local," but America's tribal nations demonstrated this as a truism centuries earlier.

Second, tribal governments utterly blurred the artificial public/private distinction that has captivated the intrigue of political scientists and legal scholars alike since the Age of Enlightenment, when the concept first appeared in the works of Rousseau ${ }^{15}$ and Locke. ${ }^{16}$ The dichotomy is succinctly explained in a recent article exploring the privacy rights of women and domestic violence by Prof. Rebecca Hulse of William and Mary University. She defines the public/private distinction as a means of explaining "social mechanism," with the private sphere encompassing "discourse relegated to the domestic," and the public sphere encompassing

\footnotetext{
${ }^{12}$ Angelique A. EagleWoman, The Philosophy of Colonization Underlying Taxation Imposed Upon Tribal Nations Within the United States, 43 Tulsa L. Rev. 43, 44 (2007)

${ }_{14}^{13} I d$.

${ }_{15}^{14} \mathrm{Id}$.

${ }^{15}$ See Rousseau, On the Social Contract, Book I § 6, available at http://www.constitution.org/jjr/socon.htm (Accessed April 2, 2012).

${ }^{16}$ See John Locke, Second Treatise of Government, Chapter VII $§ 77$ - $§ 89$ (Hackett 1980).
} 
discourse related to the "political, or alternatively economic." ${ }^{17}$ While the public/private dichotomy has been an important methodological tool for centuries, Prof. EagleWoman's work indicates that there simply was no artificial division of life into public and private spheres among most pre-contact, tribal governments. Quite the contrary, tribal notions of spirituality regularly played a key role in the governing decisions of many of America's Indian tribes, ${ }^{18}$ and domestic concerns very much impacted the political and economic affairs of the public sphere. ${ }^{19}$

Finally, it is important to note that pre-contact tribes had a vastly different concept of the wealth redistribution, and taxation than governments today. First, in her article discussing “tribalist economics," Prof. EagleWoman describes a vast network of tribal commerce bolstered by a cross-section of industries including fishing, hunting, agriculture, recreation, and even pharmaceuticals. ${ }^{20}$ This tribal trade system was not only a crucial part of the tribal economic structure, but it also served as the principal social safety net for tribal communities. ${ }^{21}$ Once individuals within a tribe had accumulated material wealth, tribal social obligation required those with means and social status to share a portion of their capital with "those in need."22 In turn, high net worth members of the community would convene a special ceremony in the form of a feast, giveaway, or potlatch that allowed some of their material goods to be redistributed among the community. ${ }^{23}$ The result of these ceremonies was a self-sustaining "circle of giving and receiving" that allowed tribal communities to attend to the needs of its citizens. ${ }^{24}$

\footnotetext{
${ }_{17}^{17}$ Rebecca Hulse, Privacy and Domestic Violence in Court, 16 Wm. \& Mary J. Women \& L. 237, 240 (2010)

${ }^{18}$ See Raymond D. Austin, Navajo Courts and Navajo Common Law: A Tradition of Tribal Self-Governance (U. Minn. Press 2009)

${ }^{19}$ EagleWoman, supra $\mathrm{n} .12$ at 44.

${ }^{20}$ Angelique A. EagleWoman, Tribal Nations and Tribalist Economics: The Historical and Contemporary Impacts of Intergenerational Material Poverty and Cultural Wealth Within the United States, 49 Washburn L.J. 805,806 (2010).

${ }^{21}$ Id. at 806 .

${ }^{22} I d$.

${ }^{23}$ Id.

${ }^{24}$ Id. at 807.
} 
While the redistribution of wealth is the primary aim of both the tribal social safety net, and modern governmental taxation schemes, the tribal system of redistribution net was fundamentally different in that it was purely philanthropic. There was no governmental entity designated to enforce the custom. Instead, the entire tribal philanthropic system was safeguarded by "societal norms that required the redistribution of wealth to attain community status." ${ }^{25}$ The process was further entrenched within tribal societies because tribal leaders were selected on the basis of how they dispersed their wealth to the community. ${ }^{26}$ Far from being coercive, those who sought positions of political leadership in a tribal governmental structure actually had a strong self-interest in the redistribution of their wealth.

In sum, prior to contact with European powers, tribal governments in the United States were complex, diverse, and vibrant. They were inherently local in scope with little distinction for public and private spheres. Moreover, pre-contact tribal governments were complex, having constructed vast networks for trade and commerce, complete with a robust scheme for the redistribution of wealth rooted in tribal social norms of philanthropy. Tribal governments were, in brief, competent governmental systems that were culturally, and socially appropriate for their respective communities. ${ }^{27}$

\footnotetext{
${ }^{25} I d$. at 806 .

${ }^{26}$ Id.

${ }^{27}$ Miriam Jorgensen Ed., Rebuilding Native Nations: Strategies for Governance and Development, 24 (U. Ariz. Press 2007).
} 


\section{CHAPTER 2}

\section{FEDERAL INDIAN LAW AND THE DESTRUCTION OF TRIBAL INSTITUTIONS}

Despite the existence of competent of tribal governments prior to contact with European powers, the colonial settling of North American ushered in a systemic, and systematic destruction of tribal institutions rooted in the earliest principles of English common law. In order to critically evaluate the legal principles of Federal Indian law and suggest an alternate model for Indian rights, it is first necessary to understand the major principles underlying modern Federal Indian Law as it exists today. There are three legal principles found in some of the earliest opinions of the U.S. Supreme Court that have come to serve as the foundation for much of modern Federal Indian law. These principles are the doctrine of discovery; the doctrine of trust; and the doctrine of Congressional plenary power over Indian affairs.

\section{A. Three Pillars of Modern Federal Indian Law}

The first pillar of modern Federal Indian Law actually had its genesis in an obscure, 1608 opinion of the English Court of Common Pleas - which was then the second highest court in the English legal system. ${ }^{28}$ In the matter of Calvin's Case, the Chief Justice, Lord Coke led the court as it grappled with whether a former Scottish citizen was considered an alien under English law, and thereby excluded from owning land in England. Citing the law of nature, Lord Coke

\footnotetext{
${ }^{28}$ Calvin's Case, 77 eng. Rep. 377 (K. B. 1608).
} 
observed that a Christian King's conquest of an "infidel" kingdom resulted in a default abrogation of the conquered peoples' laws. ${ }^{29}$ Lord Coke described an infidel kingdom as an affront "against the law of God and of nature." ${ }^{30}$ By contrast, Lord Coke concluded that in the matter of Scottish citizens, King James I succession to the throne of Scotland upon the death of Queen Elizabeth was not an English conquest of an infidel kingdom. ${ }^{31}$ Rather, the King's ascent to the throne was a statutorily prescribed coronation, rendering all Scotsmen naturalized Englishmen by law. ${ }^{32}$

Regarding the origins of Lord Coke's articulation of the right of kings to conquer infidels, Prof. Robert A. Williams's classic work The American Indian in Western Legal Thought explains that in many ways the ruling was an exercise in realpolitik. ${ }^{33}$ Coke was every bit at home in "the corridors of power," and his ruling to a great extent reflected the pragmatic need to preserve the right of kings to conquer vis-à-vis rival monarchs and infidels alike. ${ }^{34}$ But while the holding was less than ideological, its effect in the New World was no less consequential. Coke's articulation of the king's right to conquer would pave the way for the Virginia Company to begin intervening in "tribal culture for the purposes of corrective mediation" - a goal deemed not only necessary but just - thanks in large part to Lord Coke's view of conquest in Calvin's Case and his restructuring of the Virginia Company after the original colony proved to be less than successful. ${ }^{35}$ The point, of course, is that Lord Coke's views of conquest would come to have wide-ranging consequences for Indians dating almost to the time of contact with Europeans and the earliest attempts to colonize North America.

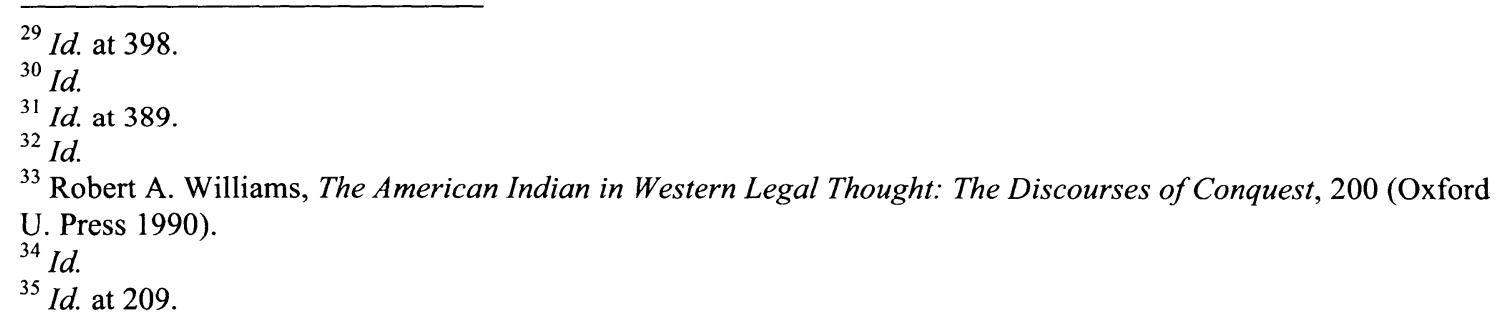




\section{The Doctrine of Discovery}

The relevance of this murky bit of English common law to the situation of American Indians in the United States is that the principle of conquest framed by Lord Coke would later become the first pillar of the Supreme Court's Federal Indian law framework as outlined in the case Johnson v. McIntosh. ${ }^{36}$ There, the Court considered whether Indian tribes had the authority to convey title to their ancestral lands. ${ }^{37}$ Crafting only a slight variation of Lord Coke's doctrine of discovery, Justice Marshall recalled the basic principle of Calvin's Case:

The potentates of the old world found no difficulty in convincing themselves that they made ample compensation to the inhabitants of the new, by bestowing on them civilization and Christianity, in exchange for independence. ${ }^{38}$

While the justification for conquest of the New World was purported to be civilization and Christianity, the basic framework for conquest was really the same foundation set by Lord Coke in 1608 , namely "that discovery gave title to the government by whose subjects, or whose authority, it was made, against all other European Governments, which title might be consummated by possession. ${ }^{.39}$ As a result, Marshall concluded that ultimate title to lands in the new world rested with European powers asserting dominion over the land, leaving Indians with only a "right of occupancy" and no authority to give title. ${ }^{40}$ Marshall reasoned that the United States had "acceded" to the doctrine of discovery after winning the American Revolution, thus inheriting title to the lands once occupied by Great Britain. ${ }^{41}$

\footnotetext{
${ }^{36}$ Johnson v. McIntosh, 21 U.S. 542 (1823)

${ }^{37}$ Id. at 572.

${ }^{38} \mathrm{Id}$. at 573 .

${ }^{39} \mathrm{Id}$.

${ }^{40} I d$. at 574.

${ }^{41} I d$. at 587.
} 


\section{The Trust Doctrine}

The second pillar of Federal Indian Law, known as the trust doctrine, followed shortly after the Court's opinion. Under the trust doctrine the United States assumed an official "guardian-ward relationship" with the 'conquered' Indian tribes. ${ }^{42}$ In the case Cherokee Nation $v$. Georgia, the Court fashioned the guardian-ward relationship as it considered whether the Cherokee Nation had standing to bring suit against the State of Georgia as it sought an injunction barring the state from enforcing its laws within Cherokee territory - laws passed by the Georgia legislature with the ultimate intent of abolishing the tribe's political structures, and seizing its land. ${ }^{43}$

Before addressing the substantive issues raised by the case, the Court was obliged to first consider the jurisdictional matter of whether the Cherokee Nation could actually sue a state under Article III of the Constitution. ${ }^{44}$ According to the Court, Article III plainly permitted a foreign state to bring suit against the State of Georgia in U.S. courts, but the remaining question was whether Indian nations constituted such "a foreign state in the sense of the constitution." As the University of Arizona's Robert A. Williams notes, the doctrine of discovery established in Johnson v. McIntosh led the Court to conclude that Indian tribes are categorically not foreign nations under the Constitution, because "the discovery doctrine...inalterably placed the tribes under the superior political sovereignty of the United States. ${ }^{\prime 46}$

But even while tribes were found to lack standing to sue, the Court nonetheless concluded that tribes constitute a form of "domestic dependent nation," one without a title to the lands they occupy, while also in a state of "pupilage" to the Government of the United States - a

\footnotetext{
${ }^{42}$ See Williams, supra n. 7 at 61.

${ }^{43}$ Cherokee Nation v. Georgia, 30 U.S. 1, 15 (1831).

${ }^{44} I$. .

${ }^{45}$ Id. at $15-16$.

${ }^{46}$ Williams, supra n.7 at 61.
} 
relationship resembling "that of a ward to his guardian." ${ }^{, 47}$ Although largely dicta at the time, the Court's ward/guardian relationship in Cherokee Nation v. Georgia has become one of the most "critical passage[s]" of the early Indian law cases, establishing the later foundation for a "trust doctrine," which now serves as "a primary protective principle of Indian rights under U.S. law." ${ }^{48}$ 3. Congressional Plenary Power Over Indian Affairs

The final pillar of modern Federal Indian law, known as the doctrine of Congressional plenary power over Indian affairs, comes from the subsequent case of the Supreme Court dealing with Indian rights. In Worcester v. Georgia, the Court heard yet another jurisdictional question of Federal Indian law. ${ }^{49}$ There, a Christian missionary from Vermont was convicted of residing within the Cherokee nation "without a license," and in flagrant violation of Georgia law. ${ }^{50}$ The defense did not deny the allegation, but argued that the laws of Georgia did not apply to the Cherokee Nation ${ }^{51}$ because they unconstitutionally interfered with the regulation and control of Indian affairs $-\mathrm{a}$ right solely belonging to the United States Congress. ${ }^{52}$

Citing its earlier precedents, the Court summarily concluded that "the constitutional powers of the federal government...must be considered the supreme laws of the land," and that "these laws throw a shield over the Cherokee Indians," in order to guarantee their rights of occupancy, and self-government. ${ }^{53}$ The Court declared that "the laws of Georgia can have no force" within the Cherokee Nation, and that the Constitution vests the United States Government with exclusive authority over Indian affairs. ${ }^{54}$

\footnotetext{
${ }^{47}$ Cherokee Nation, at 17.

${ }^{48}$ Williams, supra n. 7 at 61.

${ }^{49}$ Worcester v. Georgia, 31 U.S. 515, 537 (1832).

${ }^{50} \mathrm{Id}$. at 537.

${ }^{51}$ Id. at 538.

${ }^{52}$ Id. at $539-540$.

${ }^{53} \mathrm{Id}$. at 595.

${ }^{54} \mathrm{Id}$. at 561 .
} 
The preceding opinions, know among Indian law scholars as "The Marshall Model” of Indian rights, outline the early strains of Federal Indian law in the U.S. While the legal landscape has changed greatly in Indian Country over the course of the past two centuries, these basic fundamental tenants - the doctrine of discovery, the trust doctrine, and the doctrine of Congressional plenary power - remain the foundation of the Supreme Court's Indian law jurisprudence..$^{55}$

\section{B. Modern Federal Indian Law: The Marshall Model Legacy}

The legacy of the Marshall Model has been nothing if not consequential. As a body of law, scholar Matthew Fletcher explains that basic principles of the Cherokee cases above still "form the basis for Indian law today," providing an extraordinary example of legal predictability that has endured over most of the life of the Nation. ${ }^{56}$ Yet, over the course of the past two decades, the Supreme Court has ushered in a curious shift in its Federal Indian law principles that have all but reduced Indian Law itself to "a jumble of confusion and obfuscation." 57

This section provides a brief historical overview of the Marshall Model legacy in Federal Indian policy and demonstrates some of its key effects on Indian Country.

\section{The Reservation Era}

Despite the trust obligation assumed by the Federal Government in the Cherokee cases of the 1830 s, the burgeoning non-Indian population in the U.S. continued to encroach on tribal lands, and the Federal Government soon initiated the lengthy process of Indian forced displacement. ${ }^{58}$ The early boundaries of removal were marked by the Appalachian Mountains,

\footnotetext{
${ }^{55}$ Matthew L.M. Fletcher, The Supreme Court and the Rule of Law: Case Studies in Indian Law, 55-APR Fed. Law. 26,27 (2008).

${ }^{56} \mathrm{Id}$.

${ }^{57} \mathrm{Id}$.

${ }^{58}$ Marc Slonim, Indian Country, Indian Reservations, and the Importance of History in Indian Law, 45 Gonz. L. Rev. 517, 519 (2010).
} 
extending from Lake Erie in the North to Georgia in the South. ${ }^{59}$ But by 1830 Congress passed the Indian Removal Act, which provided for the removal of Indian tribes even further West past the Mississippi river, and redefined Indian country to exclude lands located within the borders of states East of the Mississippi. ${ }^{60}$ The result of the Federal removal policy was the reservation era of Federal Indian law, ${ }^{61}$ whereby the U.S. Government continued to accumulate formerly tribal lands while corralling tribes "on reservations within their aboriginal domain." 62 The first reservations were located in the Midwest in areas that had not yet been widely settled, but as the non-Indian population expanded further westward, Indian reservations became increasingly common throughout the American west. ${ }^{63}$

In addition to the harmful effects of displacement, two key events in the history of Federal Indian law also took place during the reservation era. Each event would come to mark a significant diminishment in the inherent powers of Indian tribes, creating legal ramifications for Indian people that still affect the tribal/federal relationship to this day. The first milestone was the end of federal treaty-making with Indian tribes in $1871 .^{64}$ Prior to 1871 , treaty-making had been "the predominate means of implementing federal Indian policy." ${ }^{\circ 5}$ Before losing Congressional favor, ${ }^{66}$ treaties accomplished a variety of federal prerogatives ranging from the extinguishment of Indian land claims to the establishment of Indian reservations. ${ }^{67}$ Perhaps, most consequentially, treaties provided the U.S. Government with the "legal means to take vast

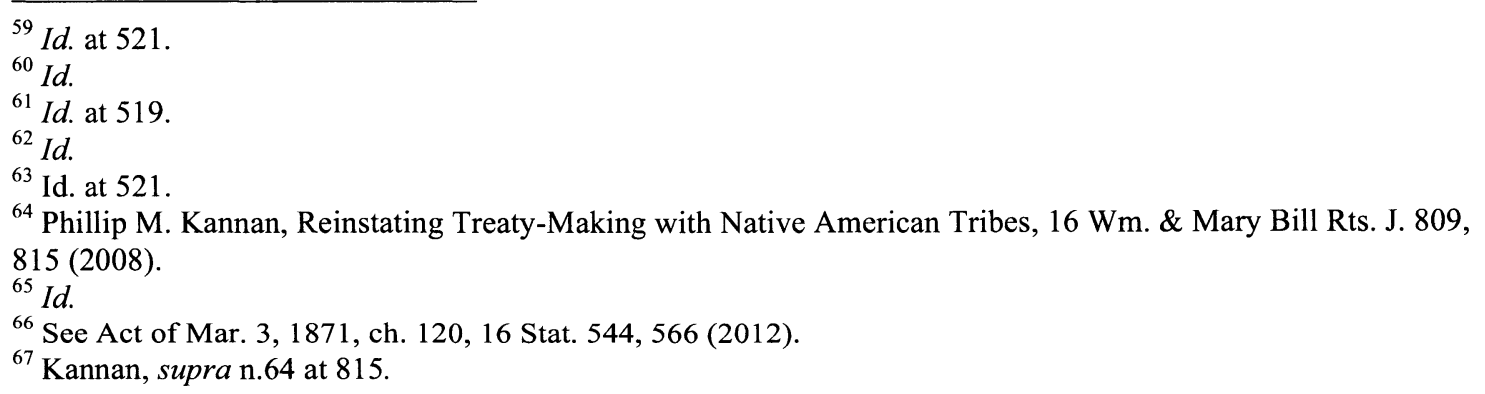


quantities of Indian land" and to remove tribes from their ancestral territories. ${ }^{68}$ Fundamentally, though, the end of treaty-making with tribes resulted in a new balance of power between tribes and the Federal Government. Rather than government-to-government negotiations, the end of treaty-making marked the beginning of Indian policy by Federal fiat. Indian policy-making no longer much concerned the input of Indians so much as it concerned the whims of Congress and the President. ${ }^{69}$

The second key event during the reservation era was the further diminishment of tribal criminal jurisdiction through the passage of the Major Crimes Act of 1885. Prior to the enactment of the Major Crimes Act, the Supreme Court considered the matter of Ex Parte Crow Dog in $1883 .^{70}$ There, Crow Dog killed Spotted Tail on the Brule Sioux Reservation, and was tried under Sioux customary law. ${ }^{71}$ Crow Dog was ultimately convicted under tribal law and was sentenced to pay Spotted Tail’s family " $\$ 600$ in cash, eight horses, and one blanket." $"$ Shortly after his conviction under tribal customary law, Crow Dog was also prosecuted under federal law where he was convicted of Spotted Tail's murder and sentenced to death. ${ }^{73}$ Crow Dog subsequently petitioned the U.S. Supreme Court for a writ of habeas corpus. ${ }^{74}$ In considering Crow Dog's petition, the Court dismissed the federal conviction for lack of jurisdiction, finding that the Sioux Indians were preserved a fundamental right of "self-government," which included the regulation of their own affairs and the right to administer their own laws and customs. ${ }^{75}$ While the holding was a major victory for tribal-self government and measured separatism, as University of New Mexico Law School Dean Kevin Washburn notes, "in holding that Congress

${ }^{68} \mathrm{Id}$. at 817 .

${ }^{69} \mathrm{Id}$. at 818 .

${ }^{70}$ Ex Parte Crow Dog, 109 U.S. 556 (1883).

${ }_{71}^{71}$ Kevin K. Washburn, Federal Criminal Law and Tribal Self-Determination, 84 N.C. L. Rev. 779, 800-801 (2006).

${ }^{72} I d$. at 801 .

${ }^{73} \mathrm{Id}$.

${ }^{74} \mathrm{Id}$. at 802.

${ }^{75}$ Id. 
had not explicitly abrogated existing federal treaties, the Court invited Congress to enact law creating such jurisdiction." ${ }^{76}$

The Congressional response to Ex Parte Crow Dog was the enactment of the Major Crimes Act of 1885 . The legislation would summarily remove tribal authority to prosecute major crimes committed within Indian Country, granting federal jurisdiction over the crimes of "murder, manslaughter, rape, assault with intent to kill, arson, burglary, and larceny."" The legislation was premised upon the assumption that tribal laws were "inadequate" to handle major crimes, thereby providing a legislative answer under the auspices of Congressional Plenary Power ${ }^{78}$ over Indian affairs to the Supreme Court's opinion in Ex Parte Crow Dog. ${ }^{79}$ For Indian tribes, the result of Ex Parte Crow Dog and the Major Crimes Act was similar to the result of the end of treaty-making: the further diminishment of tribal self-governance. Whereas the end of treaty-making affected the relational power dynamic between tribes and the federal government, the diminishment of tribal criminal jurisdiction under the Major Crimes Act directly affected tribal authority to enforce their own criminal laws and customs. As Prof. Washburn notes, the legislation amounted to little more than "a simple and straightforward act of colonization."

\section{The Allotment Era}

While the end of treaty-making and the erosion of tribal criminal jurisdiction in Indian Country marked significant events toward the end of the reservation era, one of the most damaging federal policies to tribal institutions and cultures came with the passage of the General Allotment Act of 1887 and the succeeding period of Federal Indian law known as the Allotment

\footnotetext{
${ }^{76}$ Id. at 803 .

${ }^{77}$ Id. at 804.

${ }^{78}$ See U.S. v. Kagama, 118 U.S. $375,384-385$ (1886).

${ }^{79}$ Washburn, supra n.71 at 803.

${ }^{80} \mathrm{Id}$. at 809 .
} 
Era. In her classic paper on the history of the Allotment Era, Prof. Judith Royster notes that even after tribes had been removed to reservations west of the Mississippi River, non-Indian settlement of western U.S. territories continued unabated.$^{81}$ As would be settlers pushed for additional lands, "the 1880 s witnessed the fundamental shift in federal policy from separatism within reservations to assimilation." 82 The key tool for bringing about the federal goal of assimilation was to transition from tribal structures of communal land ownership to a private property model that broke up reservation system. ${ }^{83}$ Through the General Allotment Act of $1887,{ }^{84}$ Congress accomplished this transition by divvying up reservation lands into allotments for individual Indians, and by opening up the remaining "surplus lands" to non-Indian settlement. ${ }^{85}$

The effects of allotment policy and its later amendments were devastating to tribal cultures and institutions. Under the original statute, Indian allotments were held in trust for a period of twenty-five years before the Indian allottee could receive a patent in fee. ${ }^{86}$ During this trial period of ownership, Indian allottees were expected "to assimilate to agriculture, to Christianity, and to citizenship." ${ }^{87}$ Assuming the Indian allottee assimilated, at the end of the twenty-five year period the trust was terminated, and the individual received alienable title to the land in fee simple, placing the landowner under the civil and criminal jurisdiction of the state in which the allotment was located ${ }^{88}$ But the trust period under the original act was short-lived. Assimilation proponents came to view the twenty-five year trust period as a hindrance to the goal of assimilation and amended the legislation ${ }^{89}$ to allow for the Secretary of the Interior to issue

\footnotetext{
${ }^{81}$ Judith V. Royster, The Legacy of Allotment, 27 Ariz. St. L.J. 1, 7 (1995).

${ }^{82} \mathrm{Id}$. at 9.

${ }^{83} \mathrm{Id}$.

${ }^{84}$ See The General Allotment Act, Feb. 8, 1887, c. 119, 24 Stat. 388 (1887).

${ }^{85}$ Royster, supra $\mathrm{n} .81$ at 9.

${ }^{86} \mathrm{Id}$. at 10 .

${ }^{87} I d$.

${ }^{88} \mathrm{Id}$.

${ }^{89}$ See The Burke Act of 1906, 34 Stat. 182 (1906).
} 
patents in fee whenever an Indian allottee was deemed able to manage his or her affairs. ${ }^{90}$ Assuming such a "premature patent" was issued, the allotment was both immediately alienable and subject to taxation..$^{91}$

The premature patent policy described above resulted in the issuance of an "alarming" number of patents to Indian allottees with relatively little verification of the allottees' competency to manage their newly acquired lands. ${ }^{92}$ With their lands only recently alienable and subject to taxation, many Indian landowners simply sold their lands or found them abruptly liquidated to pay back taxes..$^{93}$ The end result was that some "two-thirds of all the land allotted...passed into non-Indian ownership."’94

Though the Indian allotment policy had the effect of destroying communal landownership and yielded only mixed results in the federal goal of assimilation, this was not the most damaging policy to the diminishing tribal land base. The surplus lands policy of the General Allotment Act, which opened non-allotted lands to non-Indian settlement, accounted for two-thirds of lost tribal lands during the allotment era. ${ }^{95}$ Most surplus lands were lost in the wake of the Supreme Court's opinion in Lone Wolfv. Hitchcock. ${ }^{96}$ There, the Court considered whether a tribe's consent was necessary to cede a reservation's surplus lands as stipulated under the original language of the General Allotment Act. ${ }^{97}$ The Court held that no such consent was necessary. ${ }^{98}$ According to the Court, Congress in its plenary power over Indian affairs was presumed to have acted in "perfect good faith in the dealings with the Indians," and cession

\footnotetext{
${ }^{90}$ Royster, supra $\mathrm{n} .81$ at $10-11$.

${ }^{91} \mathrm{Id}$. at 11 .

${ }^{92} \mathrm{Id}$. at $11-12$.

${ }^{93}$ Id. at 12 .

${ }^{94} \mathrm{Id}$.

${ }^{95} \mathrm{Id}$ at 13.

${ }^{96}$ Lone Wolf v. Hitchcock, 187 U.S. 553 (1903).

${ }^{97}$ Royster, supra n.81 at 13.

${ }^{98}$ Lone Wolf, 187 U.S. at 568.
} 
agreements such as those contemplated under the General Allotment Act were beyond the review of the Courts regardless of whether Congress abided by the law or not. ${ }^{99}$ With this precedent in hand, Congress passed a number of surplus land acts, opening up the surplus lands of the reservations to settlement. ${ }^{100}$ As Prof. Royster notes, the Lone Wolf opinion combined with Congress's surplus lands policy, triggered a radical shift in the assimilation objectives of the allotment era. ${ }^{101}$ The federal goal was no longer to assimilate Indians into society, but to facilitate the non-Indian settlement of the western U.S. ${ }^{102}$

\section{Indian Reorganization}

As Indian land losses mounted, reformers and critics of the assimilation policy rallied behind the Meriam Report of 1928, a Rockefeller Foundation document, which outlined how the General Allotment Act had left Indians poor, unhealthy, and unable to manage the allotments that had been forced upon them. ${ }^{103}$ On this score, former Bureau of Indian Affairs Assistant Secretary Kevin Gover describes the Federal Government's allotment policy as an "abject failure of the Bureau of Indian Affairs to protect Indians from sharp dealing in managing their land." 104 While the Meriam Report was compelling, the policy of allotment remained unchanged during roughly the first three decades of the1900s. ${ }^{105}$ Only the Great Depression and the New Deal programs ushered in by President Franklin Roosevelt's election in 1933 were enough to overcome assimilationist intransigence in Indian Affairs. ${ }^{106}$ Soon Federal power expanded into

\footnotetext{
${ }^{99}$ Id.

${ }^{100}$ Royster, supra $\mathrm{n} .81$ at 14.

${ }^{101} I d$.

${ }^{102} I d$.

${ }^{103}$ Kevin Gover, An Indian Trust for the Twenty-First Century, 46 Nat. Resources J. 317, 329 (2006).

${ }^{104}$ Id.

${ }^{105} \mathrm{Id}$.

${ }^{106} I d$. at $329-330$.
} 
multiple areas of the private sphere and an expanded Federal role in Indian affairs followed shortly thereafter. ${ }^{107}$

The main catalyst for change in Federal Indian policy during the reorganization era was the appointment of John Collier as Commissioner of Indian Affairs. ${ }^{108}$ Collier's appointment led to the enactment of the Indian Reorganization Act of 1934 (IRA), which brought about an abrupt change to the assimilationist policies of the Federal Government. ${ }^{109}$ The legislation, in keeping with its eponymous title, first sought to reorganize Indian tribes by allowing them to adopt constitutional forms of government that purported to help them "exercise the inherent sovereignty of the Tribes." ${ }^{110}$ Second, to address the woeful economic plight of American Indians, the IRA also granted Federal corporate charters to tribes that sought to manage their economic objectives through corporate entities and created revolving credit programs as a means of stimulating economic development in Indian Country. ${ }^{111}$ Third, regarding the Federal Government's devastating allotment policies, the IRA authorized the Secretary of the Interior to take lands into trust for tribes and individual Indians, creating an indefinite trust status for Indian lands and placing "more, not less, Indian land...under federal supervision." 112

While the reorganization era implemented major changes to the structure of tribal governments and effectively ended the allotment era, the IRA did not address the growing problem of fractionated ownership of Indian allotments. ${ }^{113}$ As the generation of original, Indian allottees passed away, lack of probate and estate planning resulted in allotments being split between the heirs of the allottees. When these heirs passed away, the fractionated interests

\footnotetext{
${ }^{107} \mathrm{Id}$.

${ }^{108}$ Id. at 330 .

${ }^{109} I d$.

${ }^{110} I d$.

${ }^{111} I d$.

${ }^{112} I d$. at 331 .

${ }^{113}$ Id.
} 
became further divided between the heirs of the heirs, and so on. The IRA also failed to address Indian lands lost under the Burke Act noted in the previous section, and did little to restore Indian lands lost to homesteaders under the surplus lands provision of the General Allotment Act.

\section{Termination}

Given the vacillations of Federal Indian policy described thus far, it should come as little surprise that assimilationist trends did not subside during the reorganization era. Following the reforms under John Collier, following World War II, the Federal Government once again adopted an assimilationist approach to Indian policy aimed at further weakening tribal institutions and absorbing Indian tribes into non-Indian society. At least some of these termination era policies were driven by frustration with the inability of the IRA to turnabout the plight of Indians quickly. Rather than adopt further reforms, Congress opted to move ahead the policy ${ }^{114}$ of termination in $1953 .{ }^{115}$

The policy of termination was elegant in its simplicity, but profoundly disturbing for tribes in its application. The resolution noted the policy of Congress was "to make the Indians within the territorial limits of the United States subject to the same laws and entitled to the same privileges and responsibilities as are applicable to other citizens of the United States, to end their status as wards of the United States" as rapidly as possible. ${ }^{116}$ The pernicious language of the policy was not the provision dealing with citizenship, but the language ending the ward/guardian relationship between tribes and the federal government. The statement ending the ward/guardian relationship set in motion a series of legislative acts that not only ended the reforms made under

\footnotetext{
${ }^{114}$ See 83 H. Con. Res. 103, August 1, 1953, 67 Stat. B132 (1953).

115 Michael C. Walch, Terminating the Indian Termination Policy, 35 Stan. L. Rev. 1181, 1185 (1983).

${ }^{116} 83$ H. Con. Res. 103, August 1, 1953, 67 Stat. B132 (1953).
} 
John Collier but also ended the relationship between the Federal Government and a number of tribes specifically targeted by Congress for termination. ${ }^{117}$

The immediate, institutional result of the termination era policies for some 110 affected tribes $^{118}$ was the loss of all governing authority over "tribal members and their recognition by the United States as sovereign entities." ${ }^{119}$ This profound change in the tribes' political status also initiated a long-term ripple effect that resulted in the terminated tribes' loss of tax exemptions, all benefits that the tribes had formerly received under the Federal Government's Indian programs and, more fundamentally, their recognition as Indians. ${ }^{120}$ Even for those tribes not terminated, Congressional policies still sought to undermine tribal institutions and structures, particularly as those institutions sought to exercise jurisdiction over non-members. In the same year of the termination policy, Congress also passed Public Law 280, ${ }^{121}$ which transferred tribal court jurisdiction in the States of California, Minnesota, Nebraska, Oregon, and Wisconsin to each states' respective court system. ${ }^{122}$

The social effects of the termination era were every bit as devastating as the institutional effects. For the affected tribes, termination led to the sale of massive amounts of land within the boundaries of former reservations. ${ }^{123}$ The disestablishment of these reservations precipitated the need for yet another forced relocation of the erstwhile tribal members still living within the reservation boundaries. ${ }^{124}$ And while the termination policy was supposed to assimilate Indians into American society, Indian education levels remained woefully inadequate for the offreservation job market, and was further exacerbated by the Indians' antipathy toward becoming

\footnotetext{
${ }^{117}$ Walch, supra n. 115 at 1188.

${ }^{118}$ Id. at 1186 .

${ }^{119}$ Id. at 1188 .

${ }^{120} I d$.

${ }^{121}$ Pub. L. No. 83-280, 67 Stat. 588 (1953).

${ }^{122}$ Walsh, supra n. 115 at 1185.

${ }^{123}$ Id. at 1189 .

${ }^{124}$ Id.
} 
integrated into a culture that was not their own. ${ }^{125}$ As a result, Indian tribes lost tribal revenue and resources, while also becoming "liable for state income, property, and sales taxes." 126 Without jobs and education, the terminated tribes and their tribal members were not long able to support themselves. ${ }^{127}$ The supreme irony of the Federal termination policy was that the terminated Indians were forced to exchange one form of state wardship for another ${ }^{128}$ Rather than being wards of the state as tribal nations under the Marshall Model, the terminated Indians became wards of the state as individuals and families under state social welfare programs.

\section{Self-Determination Era}

Given the ill effects of the termination era, it was not long before Congress again reversed course and enacted a basic shift in its Federal Indian policy. By the election of President Kennedy, most Indian law scholars including UNM's Kevin Washburn agree that the elements of the tribal self-determination era had already begun an about-face from the 1950s Congressional policy of termination. ${ }^{129}$ But it was not until the administration of President Richard Nixon that Federal Indian policy took a substantially different course. ${ }^{130}$ After President Nixon announced his "self-determination policy," the first piece of legislation to follow was the Indian SelfDetermination Act of $1975 . .^{131}$

The Indian Self-Determination Act was significant for Indian tribes for two key provisions. First, the law provided the opportunity for tribes to identify services then assumed by the Federal Government and opt to provide the same services through tribal governments. ${ }^{132}$ The crucial point for tribes was that rather than forcing cash-strapped tribes to shoulder the cost of

\footnotetext{
${ }^{125} \mathrm{Id}$.

$126 \mathrm{Id}$.

127 Id.

${ }^{128} \mathrm{Id}$.

${ }^{129}$ Kevin K. Washburn, Tribal Self-Determination at the Crossroads, 38 Conn. L. Rev. 777, 779 (2006).

${ }^{130} \mathrm{Id}$.

${ }^{131}$ Pub. L. No. 93-638, 88 Stat. 2206 (1975).

${ }^{132}$ Washburn, supra $\mathrm{n} .129$ at 779.
} 
assuming new governmental obligations, the Indian Self-Determination Act allowed for tribes to negotiate "638 contracts" for specific services with the Bureau of Indian Affairs to off set the new financial outlays. ${ }^{133}$ This marked a "widely hailed" improvement in Indian policy that successfully allowed tribes to assume greater authority in the exercise of self-government. ${ }^{134}$

Second, on the heels of the original Indian Self-Determination Act, the legislation was "broadened dramatically in 1994" to allow tribes to negotiate for large block grants with the Department of the Interior to provided "virtually all federal services on a reservation." 135 While the previous iteration of the law required tribes to comply with a number of reporting requirements, the 1994 amendment allowed tribes a wide range of discretion in allocating federal funds acquired under the block grants. ${ }^{136}$ The result of the policy change was that tribes had greater ability to set priorities in providing services and programs to tribal members. ${ }^{137}$

According to Dean Washburn, more than half of the BIA budget is distributed to tribes under the tribal self-determination policy. ${ }^{138}$

Another important milestone of the self-determination era was the passage of the Indian Civil Rights Act of $1968 .{ }^{139}$ There, Congress sought to impose the Bill of Rights on Indian tribes as a means of subjecting the tribes to the principles of U.S. constitutional limitations of government. ${ }^{140}$ Formerly, tribes had not been subject to such constitutional restraints because their sovereignty derived from a source apart from the Federal Government and because they were not integrated into the 14th Amendment applying the Bill of Rights to the states. ${ }^{141}$ The

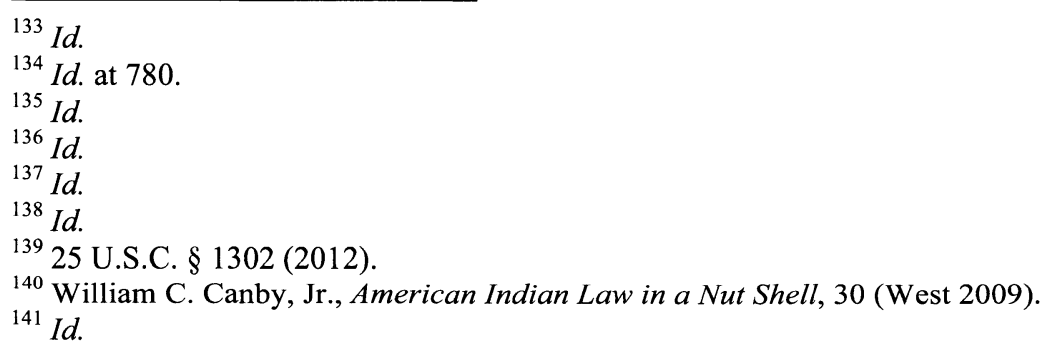


initial result of the ICRA was undoubtedly an intrusion into the sovereignty of tribes. ${ }^{142}$ Whereas tribes had not previously been incorporated into the Constitutional structure, by an act of legislation they were suddenly obliged to comply with the civil rights provisions of a foreign government without regard to their customary laws and traditions. Yet, this concern was mitigated within ten years of the act in the Supreme Court's opinion in Santa Clara Pueblov. Martinez. ${ }^{143}$ There, a Pueblo woman filed suit under the IRCA's equal protection provisions claiming that the tribal custom denying tribal membership to the children of females marrying outside the tribe amounted to sex-based discrimination. ${ }^{144}$ But the Court found that the ICRA did not provide a cause of action in Federal Court, and that Congress explicitly limited the remedy available under the Act to the writ of habeas corpus. ${ }^{145}$ Moreover, the Court flatly held absent "unequivocal expression of contrary legislative intent," that "suits against the tribe[s] under the ICRA are barred by its sovereign immunity from suit." ${ }^{146}$ The result of the ruling was to confine the ICRA's application "almost entirely to reviewing actions of the tribal courts or police in criminal cases." 147 Perhaps more troubling is that it limits "potential violations of federal law without a federal remedy." ${ }^{148}$ While this would seem contrary to the liberty interests of American Indians, noted Indian customary law scholar Justice Raymond Austin explains that some tribal courts have actually "accorded individuals more [civil liberties] protection than the American

\footnotetext{
142 Id. at 31 .

143436 U.S. 49 (1978).

${ }^{144} \mathrm{Id}$. at $52-53$.

${ }^{145} I d$. at $60-61$.

${ }^{146} \mathrm{Id}$. at 59.

${ }^{147}$ Canby, supa n. 140 at 402.

${ }^{148}$ Id. at 405.
} 
courts." 149 As the law stands now, the exclusive remedy "for the non-criminal portions of the Indian Civil Rights Act" lies within the tribal courts. ${ }^{150}$

Finally, another important provision of the ICRA is that effectively ended the policy of Public Law $280 .{ }^{151}$ Under the ICRA, states were barred from asserting civil and criminal jurisdiction in Indian Country absent the consent of the tribes affected, and offered the opportunity to retrocede jurisdiction over Indian Country back to the Federal Government. ${ }^{152}$ In practice, P.L. 280 had been a burden on the states as well as on the tribes, requiring states to expend additional law enforcement resources, particularly, to cover their expanded jurisdiction over Indian Country. Yet, out of the 150 tribes affected by P.L. 280, only 31 have managed to persuade the states to retroceded jurisdiction under the ICRA provisions. ${ }^{153}$

\section{Narrowing Tribal Authority Over Nonmembers}

The trend of the self-determination era has been to expand the authority of tribal governments. No Federal Indian policy to the contrary has ever been articulated by any Presidential administration or Congress. Yet within the judiciary, Indian self-determination has been met with decidedly mixed results. The trend in the courts, as noted by Judge Canby, has been for the judiciary to routinely constrain the authority of tribal courts whenever matters arise involving the exercise of tribal authority over nonmembers. ${ }^{154}$

The effects of this judicial philosophy of tribal authority constriction have been most damaging in the area of criminal law. Since the late 1970s, tribes have been flatly barred from

\footnotetext{
${ }^{149}$ Raymond D. Austin, American Indian Customary Law in the Modern Courts of American Indian Nations, 1 Wyo. L. Rev. 351, 372 (2011).

${ }^{150}$ Canby, surpa n.140 at 405.

${ }^{151} I d$. at 31 .

${ }^{152} I d$.

${ }^{153}$ See Carole Goldberg, In Theory, In Practice: Judging State Jurisdiction in Indian Country, 81 U. Colo. L. Rev. 1027, 1063 (2010).

${ }^{154}$ Canby, supra n.140 at 34.
} 
exercising criminal jurisdiction over non-Indians. ${ }^{155}$ In the case of Oliphant v. Suquamish Tribe, non-Indians assaulted a tribal police officer and resisted arrest, but neither the state nor federal government opted to prosecute the defendants. ${ }^{156}$ When the tribe decided to prosecute, the defendants applied for a writ of habeas corpus to the Federal Courts arguing that the tribe lacked criminal jurisdiction over non-Indians. ${ }^{157}$ After denials of their application for writ of habeas corpus in federal district court and in the Court of Appeals for the Ninth Circuit, the case made its way to the Supreme Court where the outcome of the case was deemed crucial for the future exercises of tribal criminal jurisdiction. ${ }^{158}$ At stake was not only the tribal interest in the particular case, but also for the greater question of whether tribal governments in Indian Country generally would have any criminal law enforcement authority over non-Indians at all. ${ }^{159}$ Despite the potential jurisdictional complications raised by the case, the Supreme Court held that tribes flatly lacked criminal jurisdiction over non-Indians unless Congress provided an affirmative delegation of such power. ${ }^{160}$ As the late Prof. Frickey noted, the Court concluded that exercising criminal jurisdiction over non-Indians was " "inconsistent with their status" as domestic dependent nations." ${ }^{161}$

Similarly, the exercise of civil jurisdiction by tribes has also been fraught with complications. In the two most recent cases addressing tribal court civil jurisdiction over nonmembers, tribal jurisdiction was curtailed in each case. ${ }^{162}$ In Nevada v. Hicks, ${ }^{163}$ a tribal

\footnotetext{
${ }^{155}$ See Oliphant v. Suquamish Indian Tribe, 435 U.S. 191 (1978).

${ }^{156}$ Philip P. Frickey, A Common Law For Our Age of Colonialism: The Judicial Divestiture of Indian Tribal Authority Over Nonmembers, 109 Yale L.J. 1, 34 (1999).

${ }^{157} I d$.

${ }^{158} \mathrm{Id}$.

$159 \mathrm{Id}$.

${ }^{160}$ Oliphant, 435 U.S. 191, 208 (1978)

${ }^{161}$ Frickey, supra n. 156 at 36.

${ }^{162}$ Sarah Krakoff, Tribal Civil Judicial Jurisdiction Over Nonmembers: A Practical Guide for Judges, 81 U. Colo. L. Rev. 1187, 1216 (2010).

${ }^{163} 533$ U.S. 353 (2001).
} 
member sued state officials for violating federal and tribal law. ${ }^{164}$ The question of the case resulted from a state investigation of an Indian-owned residence on tribal trust land. ${ }^{165}$ When the tribal property owner sued the state officers in their individual capacities in tribal court for damage to his property, the tribal court found that it had jurisdiction over the claims. ${ }^{166}$ When the Federal District Court, and the Ninth Circuit agreed with the tribe on the matter of jurisdiction each court noted that the location of the plaintiff's home was on tribal trust land - the state officers appealed to the case to the U.S. Supreme Court. ${ }^{167}$ There, the Court was faced with an open question related to tribal civil jurisdiction, namely, whether there was a presumption against tribal jurisdiction over nonmembers on tribal trust land. ${ }^{168}$ On this point, the Court concluded that the status of the land was merely one factor out of many in determining whether the activities of nonmembers are subject to tribal jurisdiction, and that tribal court authority over non-members does not exceed what is necessary to protect tribal self-government without an express delegation of such authority by Congress. ${ }^{169}$

Similarly, in Plains Commerce Bank the Court considered a tribal civil jurisdiction question when a reservation-based business owned by tribal members, the Longs, challenged the sale of non-Indian fee land that was seized land by a non-Indian, non-reservation-based bank through which they had obtained a mortgage. ${ }^{170}$ After the land was seized, the bank renegotiated the terms of the mortgage with the Longs' Indian-owned business and included an option to purchase the lands after two years. ${ }^{171}$ When the two-year period ended, the Longs were unable to exercise their option to purchase, and the bank allegedly discriminated against them by selling

${ }^{164}$ Krakoff, supa n.162 at 1217.

${ }^{165}$ Hicks, 533 U.S. 353 at $356-357$.

${ }^{166} \mathrm{Id}$. at 357 .

${ }^{167}$ Id.

${ }^{168}$ Krakoff, supra n.162 at 1217.

${ }^{169}$ Id.

${ }^{170}$ Plains Commerce Bank v. Long Family Land \& Cattle Co., 554 U.S. 316, 320 - 321(2008).

${ }^{171} I$ d. 
the land to non-Indians under terms more favorable than the bank had offered to them. ${ }^{172}$ The business owners brought suit in tribal court, but the bank challenged the tribal court's jurisdiction. ${ }^{173}$ In response, the tribal court considered whether it had jurisdiction to hear the case, ultimately concluding that it, indeed, had jurisdiction to hear the case and ruling against the bank. ${ }^{174}$ The bank then challenged the tribal court ruling in tribal appellate court, federal district court, and the Eighth Circuit Court of Appeals on grounds that the tribal court lacked jurisdiction - losing at each level due to their consensual dealings with the tribe and its members under the Supreme Court precedent in Montana v. U.S. ${ }^{175}$ The Supreme Court granted cert to consider "whether the Tribal Court had jurisdiction to adjudicate a discrimination claim concerning the non-Indian bank's sale of fee land it owned." ${ }^{176}$ In hearing the case, the Court was not particularly concerned with whether the bank had entered into consensual dealings with the tribe or its members as it was concerned about "the effect of the remedy that the Longs sought for their discrimination claim" namely that the Longs' sought to challenge "a non-Indian's sale of nonIndian fee land" in tribal court. ${ }^{177}$ The Court concluded that such challenges were categorically excluded from tribal court jurisdiction. It held that Indian tribes cannot regulate the sale of nonIndian fee land even when it falls within the reservation boundaries because tribes are only permitted to regulate nonmember conduct that "implicates a tribe's sovereign interests." 178

The effect of both opinions for tribal civil jurisdiction is that the Court has "reversed the usual presumption regarding sovereignty when the tribe's powers over nonmembers is

\footnotetext{
${ }^{172} I d$.

${ }^{173} \mathrm{Id}$.

${ }^{174} \mathrm{Id}$.

${ }^{175}$ Id. at 323. See also Montana v. U.S., 450 U.S. 544 (1981).

${ }^{176} \mathrm{Id}$. at 320.

${ }^{177}$ Krakoff, supra n. 162 at 1222.

${ }^{178}$ Id.
} 
concerned." 179 This suggests that courts must now presume that tribal courts lack civil jurisdiction where nonmembers are involved, unless Congress has made an express delegation of authority, or if one of the two Montana exceptions applies (tribal civil jurisdiction can be found where 1) non-Indians enter into consensual dealings with the tribe or its members; 2) the conduct of non-Indians threatens the political integrity, the economic security, or the health or welfare of the tribe). ${ }^{180}$

In sum, the legacy of the Marshall Model has largely resulted in a vacillating Federal Indian policy that tends to schizophrenically expand and restrict the authority of Indian tribal governments. ${ }^{181}$ While the basic principles of the Cherokee cases above still provide a foundation for much of Federal Indian law, over the past two decades in both criminal and civil jurisdiction, the Court has consistently reigned-in the authority of tribes to enforce their laws when those laws affect nonmembers, and non-Indians in particular. While an analysis of the future of these trends is beyond the scope of this paper, it is safe to conclude that the Courts have consistently undermined tribal interests under the Marshall Model and that a new course is needed if tribal interests are to again prevail.

\section{Critical Perspectives of Federal Indian Law}

Despite its timeworn pedigree, legal scholars and critical race theorists have long condemned Justice Marshall's framework of Indian rights as a tool of colonial governance. ${ }^{182}$ The more controversial among them have even dismissed the entire American constitutional structure as little more than a white "racial dictatorship." ${ }^{183}$ While such perspectives raise a

\footnotetext{
${ }^{179}$ Canby, supra n.140 at 91.

${ }^{180}$ Id. See also Montana v. U.S., 450 U.S. 544, 565 - 566 (1981).

${ }^{181}$ See Justice Thomas's opinion in U.S. v. Lara, 541 U.S. 193, 219 (2004).

${ }^{182}$ See Williams, supra n.7 at 44.

${ }^{183}$ Michael Omi \& Howard Winant, Racial Formation in the United States: From the 1960s to the 1990s, 65-66, 67 (2d ed. 1994).
} 
number of troubling questions, critical race theory as an academic discipline provides many useful tools for understanding the state of Federal Indian Law, and interpreting the ways in which it has been used to destroy the early tribal system. This section explores the work of several renowned critical theorists, and applies their philosophy to the framework of Indian rights developed by the courts.

\section{Frantz Fanon and Compartmentalization}

Among the more extreme critical theorists was avowed leftist scholar Frantz Fanon, who penned the famous missive on decolonization titled, The Wretched of the Earth. ${ }^{184}$ There in his opening chapter "On Violence," Fanon writes extensively about the nature of the colonial system, describing it as a "compartmentalized world," consisting of both a "native sector" and a "colonist's sector." 185 Fanon remarks that the divide of the colonial situation is self-reinforcing, with one caste of people existing as a dynamic of the other. ${ }^{186}$ The result is that "the colonist derives his validity, i.e., his wealth, from the colonial system," while the colonized person's existence is reduced to that of "the "thing" colonized." 187 Fanon goes on to suggest that true liberation of "decolonization" can be achieved only through violence - of "red-hot cannonballs and bloody knives." ${ }^{188}$

I think it safe to say that Fanon's views of revolution now test the sensibilities of most scholars. Certainly within the realm of Federal Indian law, no serious academic is suggesting revolution in the United States as a means of achieving rights for Indian people. ${ }^{189}$ But Fanon's reflections on the colonial system, and the theme of inclusion/exclusion, offer a number of

\footnotetext{
${ }^{184}$ Frantz Fanon, The Wretched of the Earth (Grove Press 2004).

${ }^{185}$ Id. at 4 .

${ }^{186} I d$. at 2 .

${ }^{187}$ Id.

${ }^{188}$ Id. at 3 .

${ }^{189}$ Although Prof. Robert Odawi Porter comes the closest in his model of tribal sovereignty that emphasizes cultural distinctness rather than working within the American legal framework for change. See Robert B. Porter, The Meaning of Indigenous Nation Sovereignty, 34 Ariz. St. L.J. 75 (2002).
} 
lessons for the system of Federal Indian Law in the U.S. First, Fanon's view indicates that the Marshall Model of Indian Rights is actually a self-reinforcing structure, one maintaining a categorical separation between Native nations, and the United States itself. In Federal Indian Law, Fanon's insight on this point is starkly reflected in the Supreme Court's opinion in Johnson v. McIntosh ${ }^{190}$ There, the purpose of the opinion was to construct an entire system of inclusion and exclusion based upon an individuals' right to possess title - in the end, Indians were categorically excluded from possessing title to their ancestral lands, while non-Indians were deemed to be the heirs of 'good title' from the British. ${ }^{191}$ The Court's resolution of the matter was that the newly minted American state possessed the exclusive right of title to its territories, while the Native nations, or tribes, did not. ${ }^{192}$ Though the Court echoed the English common law of Lord Coke, the effect of the decision was merely the codification of Fanon's "native sector" and “colonists' sector."193

The second application of Fanon's inclusion and exclusion theme is the notion of colonizing powers deriving their validity vis-à-vis the colonized. Specifically, Fanon suggests that the colonial system exists as a dynamic, with colonizers and colonized both serving a necessary role within the colonial system. ${ }^{194}$ This dynamic is most clearly reflected in Cherokee Nation v. Georgia, and the advent of the trust doctrine. ${ }^{195}$ Though the Cherokee Nation fundamentally raised a procedural question in the case as it sought an injunction against the enforcement of Georgia's laws within Cherokee territory, the question addressed by the Court was a jurisdictional question regarding whether Indian nations constituted "a foreign state in the

\footnotetext{
${ }^{190}$ Johnson v. McIntosh, 21 U.S. 542 (1823).

${ }^{191} \mathrm{Id}$. at 527.

${ }^{192}$ Id.

${ }^{193}$ Fanon, supra n. 184 at 4.

${ }^{194}$ Id. at 2.

${ }^{195}$ Cherokee Nation v. Georgia, 30 U.S. 1 (1831).
} 
sense of the constitution." ${ }^{196}$ The result, of course, was that tribal nations were not foreign states, but "domestic dependent nation[s]," in a state of "pupilage" before the U.S. Government. ${ }^{197}$

Here, Fanon's concept of power validity plays an extremely practical role in the outcome of the case. A pragmatic, colonial interpretation of the result is that in order for the nascent United States to exist as a power, it could not recognize the existence of a multitude of "foreign states" within its borders. In order to validate its own sovereignty, then, it was expedient for the Court to elevate the authority of the Federal Government over the authority of tribal governments. The end product is that erstwhile sovereign tribes now exist in a state of pupilage before the U.S. Government, while the Constitution of the United States stands athwart the vestiges of tribal structures, reigning supreme as law of the land.

In a final analysis of the validity of colonial power, Fanon suggests that colonization reduces a colonized person's existence to that of "the "thing" colonized." 198 While the application is not perfect, this perception is fairly well typified in the final case of the Marshall Model in Worcester v. Georgia. Having dispensed with the Indian's right of title in Johnson v. McIntosh, and their sovereignty in Cherokee Nation v. Georgia, the Court was left to grapple with who exactly was in charge of the Indians in Worcester v. Georgia. ${ }^{199}$

The transformation of Indians from individuals to "things" in the language of the Court was really quite remarkable. While recounting the history of European/American Indian relations, the Court waxed eloquent about an "America, separated from Europe by a wide ocean...inhabited by a distinct people, divided into separate nations, independent of each other and of the rest of the world, having institutions of their own, and governing themselves by their

${ }^{196} I d$. at $15-16$.

${ }^{197}$ Id. at 17.

${ }^{198}$ Fanon, supra $\mathrm{n} .184$ at 2.

${ }^{199}$ Worcester v. Georgia, 31 U.S. 515 (1832). 
own laws. ${ }^{200}$ From the language of the description, Indians seemed to enjoy a modicum of personhood, with the Court considering them "distinct people," albeit a subordinate one subject to the pupilage of the United States per Cherokee Nation v. Georgia. But in the holding, the language of the Court describes Indians much more abstractly, even blandly, declaring that "the whole intercourse between the United States and this nation, is, by our constitution and laws, vested in the government of the United States."201

The language is conspicuous for its absence. The conclusion of the opinion is curiously missing any reference to the "distinct people[s]" inhabiting North America, along with any mention of their "separate nations," and distinct laws. ${ }^{202}$ Instead, Indians were reduced to the vague generalities of "nations" without any acknowledgement that their status as such was largely eviscerated in the Court's previous Indian law opinions. ${ }^{203}$ Of course, by this point in history, the Court was not much interested in giving structure to the term "nation" as it related to the Indians, because the ultimate purpose of the opinion was to establish Federal primacy in Indian Affairs. ${ }^{204}$ In this way, the language of the opinion mirrors Fanon's reduction of colonized persons to "the thing" conquered quite well. ${ }^{205}$ In effect, Indians went from "distinct peoples" to regulatory burdens all within one legal opinion.

\section{Michel Foucault and the Power of Malleable Rules}

Another critical theorist whose perspective offers much help in understanding the state of Federal Indian law is French philosopher and historian, Michel Foucault. In a collection of Foucault's essays titled Language, Counter-Memory, Practice, Foucault writes at length about

\footnotetext{
${ }^{200}$ Id. at $542-543$.

${ }^{201} \mathrm{Id}$. at 561 .

${ }^{202}$ Id. at 542-543.

${ }^{203}$ See Cherokee Nation v. Georgia, 30 U.S. 1 (1831).

${ }^{204}$ Worcester v. Georgia, 31 U.S. 515, 539-540 (1832).

${ }^{205}$ Fanon supra n. 184 at 2.
} 
the fraught concepts of history in his essay "Nietzsche, Genealogy, History.” In Foucault's discussion of Entstehung, or origins, he observes that the great "forces" of history are rooted in the fundamental "struggle" of power structures against one another. ${ }^{206}$ In Foucault's view, such power structures exist across the totality of being, encompassing the realms of religion, ${ }^{207}$ class,${ }^{208}$ armed conflict, ${ }^{209}$ and even law. ${ }^{210}$

At first blush, it may seem that Foucault is stating the obvious. After all, power structures exist as a matter of course, and are challenged by their disparate antitheses on a fairly consistent basis - whether it be in the form of protests, revolutions, or peaceful political processes for change. But Foucault's true insight in his analysis of force is the observation that the rules of those in power are wholly malleable, and void of any normative, qualitative, or moral value. ${ }^{211}$ Specifically, Foucault writes:

"Rules are empty in themselves, violent and unfinalized; they are impersonal and can be bent to any purpose. The successes of history belong to those who are capable of seizing these rules, to replace those who had used them, to disguise themselves so as to pervert them, invert their meaning, and redirect them against those who had initially imposed them; controlling this complex mechanism, they will make it function so as to overcome the rulers through their own rules." 212

For Foucault, rules of a system are simply the tools for controlling the opposition. They can be construed, or "perverted" depending upon the impulse of the ruler. And oftentimes they are used to manipulate any opposing "forces" in a manner consistent with the objectives of those in power.

\footnotetext{
${ }^{206}$ Michel Foucault, Language, Counter-Memory, Practice: Selected Essays an Interviews, 149 (Cornell U. Press 1977).

${ }^{207} \mathrm{Id}$.

${ }^{208} I d$. at 150 .

${ }^{209} \mathrm{Id}$.

${ }^{210} \mathrm{Id}$. at 151

${ }^{211} I d$.

${ }^{212} \mathrm{Id}$.
} 
Unlike Fanon, Foucault's discussion of history, and origins is admittedly abstract. But the concepts discussed, nonetheless, provide a unique critical insight for understanding the state of modern, Federal Indian law. First, Foucault more or less trivializes the entire concept of law in general. In his view, the rules established by legal opinions are completely bendable, dependent upon the vicissitudes of the moment. This point seems obviously useful for understanding Federal Indian law, given the Supreme Court's admittedly "schizophrenic" approach to Federal Indian policy. ${ }^{213}$ Second and more importantly, Foucault's lens of legal malleability helps to explain the contradictory elements of the Marshall Model of Indian rights. In brief, under Foucault's theory, if a legal principle seems at odds with a stated goal of policy, or the rights of American Indians, it probably is. Legal rules, like any other rules of a system, are simply “empty," and bent to suit any purpose. ${ }^{214}$

A second insight of Federal Indian law gleaned from Foucault's observations of history and genealogy is that the law is merely a tool for control. ${ }^{215}$ Returning to the Marshall Model of Indian Rights, the first instance of law as a tool for control is found in the earliest opinion of Federal Indian law in Johnson v. McIntosh. There, the question exceeded a mere issue of good title. ${ }^{216}$ The issue ultimately decided by the Court was nothing less than whether it could craft a legal justification for the conquest and dispossession of formerly Indian lands. ${ }^{217}$ In Foucault's view, it was only natural that the Court succeeded in creating such a justification for dispossession since it controlled, and indeed created the rules of the power structure - or what we conventionally call the rule of law itself.

\footnotetext{
${ }^{213}$ See U.S. v. Lara, 541 U.S. 193, 219 (2004).

${ }^{214}$ Foucault, supra n.206 at 151.

${ }^{215}$ See also Francisco Valdes, Critical Race Materialism: Theorizing Justice In The Wake of Global Neoliberalism, 40 Conn. L. Rev. 1513, 1572 (2011) (Discussing the "centrality of law in the construction, operation and maintenance of racial injustice within, and increasingly beyond, the nation-state.")

216 Johnson v. McIntosh, 21 U.S. 542, 572 (1823).

${ }^{217}$ Williams, supra n.7 at 53.
} 
The issue of law as a tool for control is also starkly evident in the Court's opinion in Cherokee Nation v. Georgia. ${ }^{218}$ Faced with a Constitutional dilemma of categorization, the Court was forced to delineate whether Indians were "foreign states," or some other genus of "nation" altogether. ${ }^{219}$ Again, Foucault would likely be unsurprised by the outcome in Cherokee Nation. In fact, this early Indian law opinion may be the most consistent with Foucault's view of legal malleability. In a single opinion, the Court stripped tribes of any of the vestiges of national sovereignty they formerly enjoyed, ${ }^{220}$ while concurrently establishing a doctrine of trust that still forms the basis of Indian rights in the U.S. today. ${ }^{221}$ To Foucault, this exercise of legal finesse would be entirely predictable, albeit somewhat duplicitous. The Court creates the rules of the legal system, and can bend them to suit its own purposes. ${ }^{222}$ As a result, it is eminently consistent under Foucault's theory of legal malleability that the Court would both strip the tribes of formal, national sovereignty, and also establish a doctrine of trust obligating the government to provide for their welfare.

Finally, law as a tool for control is obvious in the Court's opinion in Worcester $v$. Georgia, although this iteration takes a slightly different form. There, the Court's result is more akin to Foucault's description of forces dividing "against themselves." 223 Foucault argues that forces (or in the case of Indian Law, governments) tend to "wage against each other in adverse circumstances," even waging against itself. This concept is seen clearly in Worcester v. Georgia, where Indians were not so much protagonists in the case as they were bystanders caught up in the process. The real issue in Worcester was one of the earliest power struggles between the

218 Cherokee Nation v. Georgia, 30 U.S. 1 (1831).

${ }^{219} \mathrm{Id}$. at 16.

${ }^{220} \mathrm{Id}$. at 18.

${ }^{221} I d$. at 17.

${ }^{222}$ Foucault, supra n.206 at 151.

${ }^{223}$ Id. at 149. 
Federal Government and the states. The question of the case involved whether the State of Georgia could enforce its laws in Cherokee Territory, or whether the Federal Government maintained a plenary power over Indian affairs. ${ }^{224}$ Given the obvious struggle for power in the case, Foucault would interpret the matter as forces dividing against themselves. ${ }^{225}$ And because the legal rules are malleable, it is little surprise that the higher authority wins. ${ }^{226}$

\section{Nietzsche, History, and Nihilism}

Any survey of critical theory and its implications for Federal Indian law would be remiss without the mention of the father of the discipline, Friedrich Nietzsche. But before delving into Nietzsche's contributions to critical theory and its implications for Federal Indian law, it is useful to situate his perspective within the critical theorists analyzed so far.

Frantz Fanon offers a robust understanding of how the system of Federal Indian law mirrors the colonial system. His work focuses heavily on the theme of inclusion and exclusion, which can be used to deconstruct the Federal Indian law framework, demonstrating how tribal institutions were systematically destroyed by the Court. ${ }^{227}$ By contrast, Michel Foucault provides insight into the nature of the legal system, which was created in systemic opposition to tribal interests. Foucault's perspective of rules, and legal rules in particular, challenges conventional assumptions about the rule of law, and contemporary notions of justice, equality, and fairness. Far from believing in the rule of law, Foucault's perspective has echoes of Nietzschean nihilism, asserting that rules generally are objects of caprice, made by those in power to sustain their position of dominance. ${ }^{228}$ For Federal Indian law, this suggests that tribal interests operate at a

\footnotetext{
${ }^{224}$ Worcester v. Georgia, 31 U.S. 515, 560 (1832).

${ }^{225}$ Foucault, supra n.206 at 149.

${ }^{226}$ Id. at 151.

${ }^{227}$ Fanon, supra n. 184 at 4.

${ }^{228}$ Foucault, supra n.206 at 151.
} 
consistent disadvantage since rule makers (judges, governments, etc.) construct rules to reinforce their own self-interests.

At risk of oversimplifying matters, if it can be said that Fanon demonstrates how the Federal Indian law system came to be, then Foucault demonstrates how it is maintained. And in contrast to his academic progeny, Nietzsche demonstrates how the Federal Indian law system copes with the latent injustices it creates. In a collection of essays titled Untimely Meditations, Nietzsche's essay "On the Uses and Disadvantages of History for Life" outlines his thoughts on how individuals, peoples, and cultures balance the unhistorical and the historical in order to arrive at the optimal "measure of health" and accomplishment. ${ }^{229}$

Fundamentally, Nietzsche's view of history is binary, built upon an elaborate system of balance between the human penchant to live unhistorical and in the moment, and the need to live historically and cognizant of the past. ${ }^{230}$ For Nietzsche, the unhistorical is the key to happiness. ${ }^{231}$ It represents the ability to "sink down on the threshold of the moment and forget all the past." 232 But the exercise is not merely an exercise in recreation, undertaken for its own sake. For Nietzsche, the process of forgetting and living in the unhistorical is crucial, and the only means of attaining true happiness. ${ }^{233}$ The historical, by contrast, is defined as pressure, pushing man down, encumbering his steps with an "invisible burden" - a constant state of imperfection and remembrance "that can never become a perfect one," always haunting, and mocking the mind. ${ }^{234}$

Nietzsche's view of the historical and unhistorical has a number of implications for Federal Indian law. First, it typifies a jurisprudential system constantly seeking to strike the

\footnotetext{
${ }^{229}$ Friedrich Nietzsche, Untimely Meditations, 63 (Cambridge U. Press 2010).

${ }^{230} I d$. at 68 .

${ }^{231} \mathrm{Id}$.

${ }^{232} \mathrm{Id}$. at 62

${ }^{233} \mathrm{Id}$.

${ }^{234}$ Id. at 61.
} 
appropriate historical/unhistorical balance. In Johnson v. McIntosh, the Court made a fairly concerted effort in maintaining an unhistorical perspective of American Indians on the North American continent, summarily voiding their claims to land title, and establishing a legal doctrine to justify their conclusions. ${ }^{235}$ By contrast, in Cherokee Nation v. Georgia, the Court went to great lengths to dwell upon the history of American Indians in order to conclude both that they represented an inferior form of nation, and that they were the wards of the U.S.

Government, existing in a state of pupilage. ${ }^{236}$ After dithering between the unhistorical and the historical in its approach to Indian law and policy, the Court ultimately struck Nietzsche's historical/unhistorical balance in Worcester v. Georgia, erring on the side of the historical. In its opinion, the Court heavily considered the lengthy history of Federal/Indian relations to settle the matter, ${ }^{237}$ concluding that Georgia State law did not apply within Indian territories, and that the Federal Government retained plenary power over Indian affairs. ${ }^{238}$

A second way that Nietzsche's view of history can be used to deconstruct the Federal Indian law system is by evaluating how the "invisible burden of history" applies to the situation of Federal/Indian relations. ${ }^{239}$ Nietzsche writes at length about the extremes of history, noting that when history "attains a certain degree of excess, life crumbles and degenerates, and through this degeneration history itself finally degenerates too." ${ }^{240}$ Nietzsche, of course, is not arguing that history has no role to play in the life of people, and cultures. Rather, he is suggesting that when historical considerations overbalance the practical considerations of the present in the affairs of

\footnotetext{
${ }^{235}$ Johnson v. McIntosh, 21 U.S. 542, 572-573 (1823).

${ }^{236}$ Cherokee Nation v. Georgia, 30 U.S. 1, 17 (1831).

${ }^{237}$ Worcester v. Georgia, 31 U.S. 515, 542-557 (1832).

${ }^{238}$ Id. at 561 .

${ }^{239}$ Nietzsche, supra $\mathrm{n} .229$ at 61.

${ }^{240} I d$. at 67.
} 
mankind, then history's usefulness begins to abate. ${ }^{241}$ In order to strike the appropriate balance, Nietzsche advises that a historical perspective is useful insofar as it informs how one "acts," "perseveres," and "strives" for improvement in the present. ${ }^{242}$

As this view of history relates to Federal Indian law, Nietzsche's warning cuts, unsurprisingly, across historical and unhistorical lines. It offers the first perspective of Federal Indian law analyzed so far that is prospective, rather than retrospective. Viewing the scope of Federal Indian law from a historical sense, Nietzsche, would plainly counsel policy makers (including judges) to be mindful of the historic inequities, and injustices suffered by American Indians at the time of colonization, and to seek to make informed decisions that do not repeat the mistakes of the past. While this may seem like good common sense, Nietzsche's view of history is ultimately quite profound. He writes:

A historical phenomenon, known clearly and completely and resolved into a phenomenon of knowledge, is, for him who has perceived it, dead: for he has recognized in it the delusion, the injustice, the blind passion and in general the whole earthly and darkening horizon of this phenomenon, and has thereby also understood its power in history. ${ }^{243}$

This suggests that the history of Federal Indian law is effectively dead to contemporary iterations of Federal Indian policy in that there is nothing that can be done to alter it. The Marshall Model of Indian Rights and its existence and impacts cannot be historically "undone.” The best a policy maker can do is learn of its "delusion[s], the injustice[s], and blind passion[s]" in hopes of developing a Federal Indian policy that rectifies the ills of the current system.

All of the above analyses hint at the major philosophical theme driving nearly all of Nietzsche's work, nihilism. To better understand this, it is useful to undertake a brief analysis of

\footnotetext{
${ }^{241} I d$.

${ }^{242}$ Id.

${ }^{243} I d$.
} 
Nietzsche's posthumous notes in The Will to Power. ${ }^{244}$ Nietzsche defines nihilism as "that the highest values devaluate themselves. The aim is lacking; "why?" finds no answers." ${ }^{245}$ Nietzsche refines this definition a short while later in his notes, declaring that nihilism is the recognition of how it is a "waste" of strength to find meaning in anything - whether ethics, moral order, love and harmony, or even universal happiness. ${ }^{246}$ Nietzschean nihilism views any attempt at processual achievement as simply void, "becoming aims at nothing, and achieves nothing."247 Meaning has no meaning, "there is no truth, that there is no absolute nature of things nor a "thing-in-itself." ${ }^{248}$ The result of Nietzsche's nihilism is equally stark. Having reduced all systems of values, and systems of progress to meaninglessness, Nietzsche concludes that the sum total of life is the "will to power." ${ }^{249}$ Specifically, Nietzsche writes: "there is nothing to life that has value, except the degree of power - assuming that life itself is the will to power." ${ }^{250}$ Interpreting Federal Indian Law through the lens of nihilism presents two, contradictory conclusions, only one of which is useful for advancing our discussion. First, the less useful: if life, institutions, values, etc., are all utterly meaningless as Nietzsche suggests, then it functionally matters little whether the system of Indian rights in the U.S. is improved in any way. If there is no truth, then there can be no injustices or inequities to rectify because the will of the British and American conquerors to power was simply greater than that of the Indians. This conclusion suggests that the will to power simply reflects the natural state of things - granted, the natural state of things benefitted by centuries of hindsight.

\footnotetext{
${ }^{244}$ Friedrich Nietzsche, ed. Walter Kaufmann, The Will to Power (Vintage 1968).

${ }^{245} I d$. at 9.

${ }^{246} \mathrm{Id}$. at 12 .

${ }^{247}$ Id.

${ }^{248} \mathrm{Id}$. at 14.

${ }^{249}$ Id. at 37.

${ }^{250}$ Id.
} 
On the other hand, this conclusion ignores Nietzsche's final words on the state of nihilism, and his prescription for those living within its bounds. Among Nietzsche's final notes, he writes: "He who determines values and directs the will of millennia by giving direction to the highest natures is the highest man." ${ }^{251}$ Under Nietzsche's nihilistic framework, individuals should try to shape "the highest values," through the exercise of their will to power. ${ }^{252}$ This conclusion has profound, critical implications for the state of Federal Indian Law, and its future. First, if influencing, or shaping the highest values is merely the exercise of will, then tribal governments and tribal nations have every incentive to engage the process and seek self-interested policies. This is merely the exercise of the "overman," seeking to live "beyond the rulers, freed from all bonds. ${ }^{253}$ Applying the theory to Federal Indian Law, it is difficult to imagine a clearer, less realistic definition of tribal sovereignty than the one pursued under Nietzsche's framework of nihilism.

Second, and by contrast, a less militant approach to Nietzschean nihilism is to question the legitimacy of the system itself. Such an approach invites leaders of all stripes to ask whether the framework of law and governance is, in fact, a legitimate one. It invites questions of justice, racism, capability, competence, and vision. Naturally, it is this conclusion that is much more useful. In particular, Nietzschean nihilism suggests that meaning, and values, in fact have no meaning, and represent merely the will to power. ${ }^{254}$ Under Nietzsche's framework, this indicates that the "truths" of law, and the foundations of Indian rights in the U.S. are simply the machinations of power, void of moral force, and void of legal meaning but for the power wielded by those who pronounced their opinions. In this way, the Supreme Court's opinions in the

\footnotetext{
${ }^{251} I d$. at 519.

${ }^{252} \mathrm{Id}$.

${ }^{253} \mathrm{Id}$.

${ }^{254}$ Id. at 14.
} 
Marshall trilogy discussed above are just another example of power begetting power. This conclusion suggests, as critical theorists will later argue, that it is eminently appropriate to ignore the historical precedents of Federal Indian law given its foundation of racist presuppositions. ${ }^{255}$

\section{Said's Critique of Orientalism: Us v. Them}

Postcolonial theorist Edward W. Said could hardly be described as a nihilist. Said, a Princeton and Harvard trained scholar, is most famous for his efforts to raise awareness of cultural bias within the Western academic canon in the classic volume, Orientalism. There, Said writes at length about the tendency of Western academics to interpret the colonial experience through the lens of imperialist societies, calling for reform in the way that academic disciplines understand and interpret cultures different from the West. ${ }^{256}$

Said begins his work with a definition of the problem, calling orientalism a "style of thought based upon an ontological and epistemological distinction made between "the Orient" and (most of the time) "the Occident." ${ }^{257}$ According to Said, the distinction drawn between Orient and Occident is one of Western interpretation rooted in the West's penchant for "dominating, restructuring, and having authority over the Orient." ${ }^{\text {258 }}$ Said's definition is not limited to its scope, but includes a number of manifestations of the Orient/Occident divide across the fields of literature, philosophy, politics, economics, governance, societies, and customs. ${ }^{259}$

Said calls this Western practice a "systematic discipline," that not only strengthens Western culture at the expense of other cultures, but portrays them "as a sort of surrogate and even underground self." ${ }^{260}$ Fundamentally, then, Said views the Orient and Occident relationship

\footnotetext{
${ }^{255}$ Williams supra $\mathrm{n} .7$ at 30.

${ }^{256}$ Edward W. Said, Orientalism, 1 (Vintage 1994).

${ }^{257}$ Id. at $2-3$.

${ }^{258}$ Id. at 3 .

${ }^{259}$ Id. at 2 .

${ }^{260}$ Id. at 3 .
} 
as a power dynamic, one that subjects the Orient to "varying degrees of a complex hegemony," thereby allowing the Occident to define the Orient as other - a classic battle of us v. them. ${ }^{261}$ The extent of this gulf is not to be understated. Said likens the Occident and Orient distinction to Gramsci's "cultural hegemony," calling it a European identity that perceives Europe as superior to all "non-European peoples and cultures." positional superiority," pitting Western cultural values against the values of the Orient "in a whole series of possible relationships," and never losing "the upper hand." ${ }^{\text {"263 }}$ The result is a constantly self-reinforcing system that transcends nearly every field of analysis, creating a "distribution" of cultural superiority ranging from the aesthetic to the geographic, and from the political to the moral. ${ }^{264}$

As the foregoing analysis suggests, Said's critique of orientalism is really a critique of Western culture itself. Said is particularly concerned with Western perceptions of superiority however obvious or latent they may be. In using Said's critique to deconstruct Federal Indian law, one need but turn to the language of the Indian Law's foundations to find rank examples of assumptions of Western cultural superiority. ${ }^{265}$ The facts of the case have been well covered in preceding sections. For now, it is sufficient to note language from the Court's opinion in Johnson v. McIntosh where Justice Marshall describes Indian tribes as follows:

But the tribes of Indians inhabiting this country were fierce savages, whose occupation was war, and whose subsistence was drawn chiefly from the forest. To leave them in possession of their country was to leave the country a wilderness; to govern them as a distinct people, was impossible, because they were as brave and as high spirited as they were fierce, and were ready to repel by arms every attempt on their independence. ${ }^{266}$

\footnotetext{
${ }^{261} I d$. at 5 .

${ }^{262} I d$. at 7.

${ }^{263} \mathrm{Id}$.

${ }^{264}$ Id. at 12.

${ }^{265}$ See Williams supra n.7. Williams provides a much more complete account of cultural bias against American Indians, as detailed in the opinions of the U.S. Supreme Court. Prof. Williams's views will be discussed in more detail later, but his remarkable contribution to this exercise merits mention here.

${ }^{266}$ Johnson v. McIntosh, 21 U.S. 542, 590 (1823)
} 
Considering that the opinion would ultimately divest American Indians of title to their ancestral lands, the language of the Court in reaching its conclusion is particularly troubling. First, the Court eviscerates the legitimacy of the Indian parties in question, dismissing them as little more than "fierce savages," and forest lurkers. ${ }^{267}$ Given Western presumptions of cultural superiority, the Court simply reasoned that restoring Indian title was tantamount to leaving "the country a wilderness." 268

Here, the Court's reasoning illustrates Said's Occident/Orient power dynamic especially well. The Court exercises a "flexible positional superiority" in assessing the utility of land, concluding that Western values of land development trump tribal values of subsistence. Viewing the matter as self-evident, the Court offers precious little else to bolster its own claim, and summarily voids the legitimacy of Indian claims to title. Naturally, this conclusion is disturbing for all of the reasons that Said articulates. The distinction drawn by the Court between Western and American Indian values is fundamentally rooted in the West's interpretation of itself. ${ }^{269}$ From the language of the opinion, the outcome is never in doubt, while the ultimate conclusion reflects a pattern of domination exercised by Western culture over all others. ${ }^{270}$

Further evidence of Said's critique of Orientalism is found in the second pillar or the Supreme Court's jurisprudence of Federal Indian law in the case Cherokee Nation v. Georgia. Having constrained the question to one of jurisdiction, the Court used the following language to describe the Cherokee plaintiffs:

Yet it may well be doubted whether those tribes which reside within the acknowledged boundaries of the United States can, with strict accuracy, be denominated foreign nations. They may, more correctly, perhaps, be denominated domestic dependent nations. They 
occupy a territory to which we assert a title independent of their will, which must take effect in point of possession when their right of possession ceases. Meanwhile they are in a state of pupilage. Their relation to the United States resembles that of a ward to his guardian. ${ }^{271}$

Here, Said's power relationship is evident as the Court openly asserts title over the "will" of the Indians. ${ }^{272}$ But the more telling phrase is that the Cherokee Nation exists in a "state of pupilage," resembling the relationship between "a ward to his guardian." ${ }^{273}$ While the Court notes the history of the Cherokee's treaty with the Federal Government, the guardian/ward relationship described by the Court had not been codified in any way prior to the Court's opinion in Cherokee Nation v. Georgia. Given the lack of precedent, the language bespeaks a necessary form of cultural superiority in the eyes of the Court, suggesting that a tribal nation that had existed from time immemorial could not continue to exist apart from the benevolence of the Government. The characterization of tribal nations as wards is remarkably familiar to Said's description of the Occident dubbing the Orient as its surrogate. ${ }^{274}$ It also plainly reflects Said's power dynamic, asserting Western cultural hegemony over the tribal "other."275 The conclusion also reflects the self-reinforcing nature of Said's orientalist system, and the broad "distribution" of assumptions of Western cultural superiority. ${ }^{276}$

Finally, Said's deconstruction of orientalism can be applied to the last pillar of Federal Indian law found in Worcester v. Georgia. As noted earlier, there, the Court considered the effect of Georgia law in Cherokee territory. En route to a ruling against the State of Georgia, the Court recounted the history of European/tribal interactions - in effect, describing the presumptive history of cultural superiority over the Indians. The Court described the North American

${ }^{271}$ Cherokee Nation v. Georgia, 30 U.S. 1, 17 (1831).

${ }^{272}$ Id.

${ }^{273} \mathrm{Id}$.

${ }^{274}$ Said, supra n.256 at 3.

${ }^{275} \mathrm{Id}$. at 5.

${ }^{276} \mathrm{Id}$. at 12. 
continent as "lying concealed for a series of ages," that is until the "adventurous sons" of Europe discovered the continent "in possession of a people who had made small progress in agriculture or manufactur[ing]." ${ }^{277}$ After setting the historical scene, the Court rhetorically asked:

Did these adventurers, by sailing along the coast, and occasionally landing on it, acquire for the several governments to whom they belonged...or has nature, or the great Creator of all things, conferred these rights over hunters and fishermen, on agriculturists and manufacturers? $?^{278}$

The Court ultimately reaffirmed its conclusion that discovery vested good title in the European adventurers, and that power over Indian affairs fell under the sole purview of the Federal Government. But under Said's model, the presumption of cultural superiority is really the cornerstone of the opinion. Under Said's analysis, the Cherokee Nation functions as little more than a pawn in the relational power struggle between the Federal and state governments, with each side competing for dominion and authority over or the tribal Orient. ${ }^{279}$ It is also noteworthy that the Court's approach to cultural superiority was a "systematic discipline," that strengthened the position of Western culture vis-à-vis the Indigenous peoples of the Americas ${ }^{280}$ Far from recognizing the unique cultures, governments, and extant political relationships among the tribes, the Court precipitously dismissed the Indians as hunter/gathers bereft of the cultural virtues of Western Europeans.

\section{Antonio Gramsci on Hegemony and Intellectuals}

While Said's theory of Orientalism offers much insight into our contemporary understanding of cultural hegemony, the concept is actually the provenance of Marxist scholar Antonio Gramsci. Hailing from modest means, Gramsci's life was marked by a speedy ascent to the top rank of the Italian Communist Party in 1924, and by a swift decline in health under the

${ }^{277}$ Worcester v. Georgia, 31 U.S. 515, 543 (1832).

${ }^{278} I d$.

${ }^{279}$ Said, supra n. 256 at $2-3$.

${ }^{280}$ Id. at 3. 
arrest of Mussolini's fascist regime in $1937 .{ }^{281}$ During his imprisonment, Gramsci outlined his vision for Marxist thought, beginning with a strident defense of "organic intellectuals." 282

Gramsci's view of the intellectual was expansive. He argued that each class produces its own "organic" intellectuals who specialize in the "particular technical capacit[ies]" of the society from whence they came. ${ }^{283}$ For example, feudal lords provided military capacity, while ecclesiastics held a monopoly over religion - and at various times, science, philosophy, morality, justice, etc. ${ }^{284}$ In Gramsci’s view, then, "all men are intellectuals," even though not all individuals serve as intellectuals in the society. ${ }^{285}$ Those individuals serving as intellectuals in economic and state "functionaries" tended to be the products of the "petty and middle landed bourgeoisie" children with a leg up "over the economic territory" due to their position within the society. ${ }^{286}$ Gramsci's understanding of the intellectuals in society is important to note because it significantly informs his interpretation of cultural hegemony, and the power that "the dominant group exercises throughout society. ${ }^{287}$ Gramsci argues that the ultimate achievement of Western culture is that it has become "the only historically and concretely universal culture," subsuming and assimilating the "other cultures" of world civilization. ${ }^{288}$ As a matter of process, Gramsci viewed the assimilation of world cultures into that of Western culture as the product of Western intellectuals who were able to popularize their philosophy to the masses, taking ideas from the philosophical abstract to one of praxis. ${ }^{289}$ As a result, Gramsci perceives the role of the intellectual in society as one of facilitator, leading the "people-nation" toward an "organic

\footnotetext{
${ }^{281}$ Antonio Gramsci, Prison Notebooks, xvii (International Publishers 1992).

${ }^{282}$ Id. at 6.

${ }^{283} \mathrm{Id}$.

${ }^{284}$ Id. at 7.

${ }^{285} \mathrm{Id}$. at 9.

${ }^{286} \mathrm{Id}$. at 11 .

${ }^{287}$ Id. at 12.

${ }^{288} \mathrm{Id}$. at 416.

${ }^{289}$ Id. at 417.
} 
cohesion. ${ }^{290}$ Naturally, Gramsci's view of social cohesion is state-centric, incorporating the rule of law as mechanism of coercion, and "educator," serving as the "repressive and negative aspect of the entire positive, civilizing activity undertaken by the state." ${ }^{\prime 291}$

While not all of Gramsci's social deconstructions are on point for our analysis, the selection above raises a number of implications for the state of Federal Indian law, and Indian rights in the United States. First, Gramsci suggests that cultural hegemony is achieved by the ascent of intellectuals from particular classes into positions of leadership in society. ${ }^{292}$ This view is reinforced by the Supreme Court's Indian Law jurisprudence in Johnson v. McIntosh. In deciding the matter of Indian title, the Court observed that the very act of conquest itself vest title in the conquering powers that its courts simply cannot question. ${ }^{293}$ Gramsci's view of this opinion would doubtless be quite cynical, concluding that it simply typifies landed intellectuals protecting the landed interests of the society from whence they came. ${ }^{294}$ The denial of Indian title is also consistent with Gramsci's view of cultural hegemony, which recognizes Western culture as a subsuming force, assimilating the cultures of the world in an effort to build a "concretely universal culture" comprised of the many civilizations it has left in its wake. ${ }^{295}$ Here, Gramsci would view Indian tribes as mere casualties of the process - although one far afield of his ideal philosophical praxis, and its state-centric repression of dissent. ${ }^{296}$

Finally, Gramsci's understanding of the rule of law as a mechanism of coercion is evident in the Cherokee Nation v. Georgia as the Court considered whether Indians constitute foreign nations under the U.S. Constitution. There, the Court concluded that Indian tribes are better

\footnotetext{
${ }^{290} \mathrm{Id}$. at 418 .

${ }^{291}$ Id. at 247.

292 Id. at 11.

${ }^{293}$ Johnson v. McIntosh, 21 U.S. 543, 588 (1823).

${ }^{294}$ Gramsci, supra n.281 at 6-7.

${ }^{295}$ Id. at 416.

${ }^{296}$ Id. at 247.
} 
defined as "domestic dependent nations" rather than foreign nations whose relationship to the Federal Government resembles more that of "a ward to his guardian," than one state to another. ${ }^{297}$ This conclusion of the Court is eminently consistent with Gramsci's view of law as a repressive and negative aspect of the activities of the state. ${ }^{298}$ Not only does the Court undertake the repressive action of stripping tribes of their national sovereignty, but it also frames them in the negative cast of ward, or an individual bereft of autonomy under the care of someone else.

\section{Robert Williams on Confronting the Powers That Be}

For those still skeptical about the ability of critical race theorists to deconstruct the current system of Federal Indian rights in the U.S., I hope matters will be put to rest by examining the scholarship of Robert Williams - the critical race theorist, and attorney who literally wrote the textbook on Federal Indian Law. In his latest work, Like a Loaded Weapon, Williams explores the racist language embedded in the heart of Federal Indian law legal precedents, while advocating a "singularity thesis for protecting Indian rights" in the United States. ${ }^{299}$

Williams defines his singularity thesis as the inherently difficult problem of convincing the American people that Indians possess a right to "a degree of measured separatism" and that it is in the Nation's best interest to recognize it. ${ }^{300}$ Accordingly, Williams views the quest for Indian rights as uniquely problematic since the practical result is providing some lateral authority for tribes to "rule themselves" alongside the governmental power structures that be. ${ }^{301}$ The matter is further complicated given that much of Indian Country, its homelands, and reservations are located throughout the territorial boundaries of the United States, requiring at least some assent

${ }^{297}$ Cherokee Nation v. Georgia, 30 U.S. 1, 17 (1831).

${ }^{298}$ Gramsci, supra n.281 at 247.

${ }^{299}$ Williams, supra $\mathrm{n} .7$ at $\mathrm{xxv}$.

${ }^{300} I d$. at xxxvi.

${ }^{301} I$ d. 
from Federal and State governments to according tribes greater authority over their lands. ${ }^{302}$ The potential rights permitted to tribes under the singularity thesis would, of course, create a number of potential conflicts with "the dominant society's interests or values," adding to the complexity of the problem. ${ }^{303}$ Williams identifies a number of such conflicts including the "seemingly balkanizing" nature of the Indian Rights over lands, the legitimacy of concerns from governments and citizens alike regarding matters of criminal and civil jurisdiction on the reservation, and the inapplicability of the Bill of Rights in tribal courts. ${ }^{304}$

Given the unique nature of the problem and the relatively narrow field of Indian law itself, one might be tempted to lump Williams in with the lot of Indian rights advocates who would rather avoid American courts altogether, rather than take on the deeply entrenched, and often unrecognized biases of the bench. ${ }^{305}$ But Williams dismisses such views as "simply wrong," citing the history of minority rights as evidence of the need to actually confront the courts, and the Supreme Court in particular, with the legal discourse of its precedents - a body of opinion "that views Indians as lawless savages and interprets their rights accordingly." 306

The result of Williams singularity thesis, and its principal goal of identifying and confronting racist language within Indian law precedents, is a four part exploration of the role of racist language in the Supreme Court's Federal Indian law jurisprudence. While it would not be useful to re-write the entirety of Williams's capable work, it is sufficient to note that he analyzes the three pillars of Federal Indian law discussed at length above in the work's fourth chapter titled "Indian Rights and the Marshall Court." ${ }^{307}$ Of these early opinions, Williams observes that

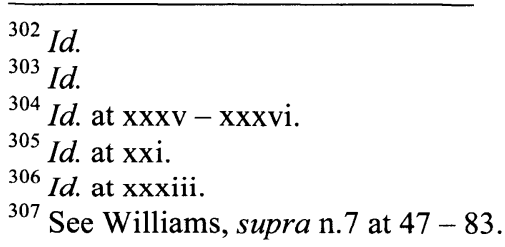


the language of racism not only permeates all three opinions, but also justifies "the legal imposition of the white racial dictatorship over tribes that had been envisioned as the ultimately intended goal of the Founder's inaugural Indian policy paradigm of treating "the Savage as the Wolf." "'308

Given that the bulk of the Marshall Court's opinions remain "good law," the longstanding outrage is that the Court still cites such racially loaded precedents. ${ }^{309}$ Williams suggests that the opinions are followed "dutifully," not because of their logical coherence but because of the aura surrounding their author, Chief Justice John Marshall. ${ }^{310}$ Not only has Justice Marshall been considered among the greatest justices of the Supreme Court, but he has also been revered among the legal community practicing Indian Law for centuries. ${ }^{311}$ According to Williams, this imbues the opinions with an otherwise unnatural "oracular status" as they relate to Indian Law that is reinforced with each successive generation of lawyers and judges through the legal principle of stare decisis - the principle that generally obliges the courts to follow precedent. ${ }^{312}$

Despite these entrenched obstacles, Williams is not a fatalist when it comes to Indian Law, and the potential for U.S. courts to change their views. In the conclusion of his critique of the Court's Federal Indian law jurisprudence, Williams suggests that advocates mount a robust challenge to the justices' "racist judicial language." ${ }^{\prime 13}$ The suggestion, however, is less a proposal and more of a warning. Noting the "racial reality" of American Indians as a historically “subordinated minority group," Williams argues that Indians and their advocates have little choice but to try and win the minds of the Supreme Court as they fight for their basic rights to

\footnotetext{
${ }^{308} I d$. at $48-49$.

${ }^{309}$ Id.

${ }^{310} \mathrm{Id}$.

${ }^{311} I d$.

${ }^{312} I d$.

${ }^{313}$ Id. at 162 .
} 
"property, self-government, and cultural survival." ${ }^{314}$ While the line of argument may seem novel in the literature of Federal Indian law, the premise underlying Williams' singularity thesis is the simple idea that the justices should be "presumed capable" of change, and reframing an “antiquated racial paradigm" for adjudicating Indian rights cases. ${ }^{315}$

Regarding the potential for changed minds on the bench, Williams promotes framing Indian rights issues before the Court using the principles of international Indigenous human rights. ${ }^{316}$ While international law may seem to be a different framework of law altogether, Williams reminds readers that it was international law, through the Doctrine of Discovery discussed above, that actually provided the historical foundation for "Indian rights in the U.S. legal system." ${ }^{317}$ Williams' new vision for Indian rights would include incorporating contemporary international law principles into the interpretive framework of the courts, ${ }^{318}$ in effect providing the justices with a legal rationale for deviating from past Indian law precedents. ${ }^{319}$ The international model would then have the Justices draw from an emerging body of international law related to Indigenous human rights, citing authoritative - though not binding - interpretations of Indigenous human rights from international legal bodies such as the International Labor Organization's Convention No. 169, the opinions of the Inter-American Commission on Human Rights, and the recently adopted U.N. Declaration on the Rights of Indigenous Peoples. ${ }^{320}$

In sum, critical race theory offers a powerful critique of the current model of Indian rights in the United States. Frantz Fanon demonstrates the self-reinforcing nature of Federal Indian

\footnotetext{
${ }^{314}$ Id.

${ }^{315} I d$. at $163-164$.

${ }^{316} \mathrm{Id}$. at 165 .

${ }^{317} \mathrm{Id}$. at 166

${ }^{318} I d$.

${ }^{319}$ Id. at 172 .

${ }^{320} I d$. at $183-195$.
} 
law's power structure, saddling tribal peoples with an Indian identity that exists as a dynamic of non-Indian culture based upon a right to title..$^{321}$

Michel Foucault's essays on history underscore the malleable nature of legal rules and laws, demonstrating how power systems are adept at manipulating both as tools of control. ${ }^{322}$ In Indian law, particular, even the Supreme Court itself has described the field as an exercise in schizophrenia adding further support to Foucault's observations. ${ }^{323}$

Nietzsche shows how individuals, groups, and governments tend to strike a balance between the lessons of history, and the pragmatic considerations of the moment, a point seen in the outcome of numerous Supreme Court opinions dealing with Federal Indian law. ${ }^{324}$ Of course, Nietzsche's ultimate critique of the Federal Indian law system is rooted in his views of nihilism, which summarily removes objective values from any decision, and reduces all judgments to the simple will to power. ${ }^{325}$ As applied to Federal Indian law, this suggests a Court practice of finessing the art of the possible with respect to Indian law issues - making legal decisions based upon pragmatic calculations, rather than the actual pursuit of justice. ${ }^{326}$

Said's critique of Orientalism represents the nascent beginnings of a call to reform from critical race theorists. He demonstrates that orientalism itself is the product of ontological and epistemological assumptions made about other cultures that may, in fact, not be grounded in cultural reality. ${ }^{327}$ This suggests that Western cultural hegemony is really a classic battle of us v. them that the West wins time and time again on the basis of its own presumption of

\footnotetext{
${ }^{321}$ Fanon, supra $\mathrm{n} .184$ at 2.

${ }^{322}$ Foucault, supra n.206 at 151.

${ }^{323}$ See U.S. v. Lara, 541 U.S. 193, 219 (2004).

${ }^{324}$ Nietzsche, supra n.228 at 62.

${ }^{325}$ Nietzsche, supra n. 244 at 37.

${ }^{326} \mathrm{Id}$. at 14.

${ }^{327}$ Said, supra n.256 at $2-3$.
} 
superiority. ${ }^{328}$ Naturally, such assumptions are easily found in the three inaugural Supreme Court opinions on Federal Indian law.

Gramsci's work is useful for explaining the way that cultural hegemony in the U.S. has been preserved through the intellectual, and political elite of the Federal Government. ${ }^{329}$ Cultural hegemony is achieved through intellectual leadership atop social hierarchies, so it is of little surprise that Federal Indian law is decided by the elite of the intellectual elite at the Supreme Court. Accordingly, the Court's role in maintaining a legal and social hierarchy would seem to corroborate Gramsci's view. Gramsci was also instrumental in typifying cultural hegemony as a subsuming force, one that assimilates cultures rather than crafting a multicultural society. ${ }^{330}$ The early opinions of Federal Indian law, which stripped Indians of both title and sovereignty are clear examples of Gramsci's theory.

And finally, Prof. Williams's critique of the U.S. system of Indian rights amply demonstrates the way in which the theorists above operate together. His singularity thesis of Indian rights advocates for a degree of separatism from the United States that is based upon confronting the Court with the Said/Gramsci theory of cultural hegemony in the racist language of the Court's precedents. ${ }^{331}$ He also echoes Foucault and Nietzsche in his understanding of the nature of the problem of Federal Indian law, situating the matter within power structures run by individuals who possess the innate capacity to change their mind when confronted appropriately and rationally. ${ }^{332}$

Critical race theory, then, ably provides a useful deconstruction of the extant system of Indian rights in the United States. But apart from Robert Williams's vision of international

\footnotetext{
${ }^{328} I d$. at 5 .

${ }^{329}$ Gramsci, supra n.281 at 11.

${ }^{330} \mathrm{Id}$. at 416.

${ }^{331}$ Williams, supra $\mathrm{n} .7$ at $\mathrm{xxxvi}$.

${ }^{332}$ Id. at $47-83$.
} 
A Libertarian Framework for Indian Rights

Indigenous human rights, critical race theory offers relatively little in the way of a new

framework for Indian rights that suitably addresses the right of measured separatism sought by

Indian tribes. To construct this framework, it is useful to turn to another field of philosophical thought - the basic principles of which are the subject of the next chapter. 


\section{CHAPTER 3}

\section{A LIBERTARIAN FRAMEWORK OF RIGHTS}

Whereas earlier I used critical race theory to deconstruct the pitfalls of the present system of Indian rights, I now intend to use libertarian philosophical theory to glean the essential tools for building a better system of Indian rights. In this chapter, my goal is to arrive at a concrete statement of Libertarian philosophical thought, while exploring the basic tools of libertarianism and its scholarly pedigree for building a new framework of Indian rights. This chapter seeks to address the following:

1) Define what libertarianism is;

2) Explore the role of government within a libertarian framework of governance;

3) Discuss the importance of freedom for securing rights; and

4) Evaluate the role of markets in establishing a rights framework.

To state matters a bit more concretely, if the present system of Indian rights has at its foundation a "racist legal doctrine," ${ }^{333}$ and this doctrine leaves tribal existence to the whims of Congress via plenary power as explored in the previous chapter, ${ }^{334}$ then what would constitute a legitimate framework for Indian rights in the United States?

\footnotetext{
${ }^{333}$ Williams, supra $\mathrm{n} .7$, at xxxil..

${ }^{334}$ See Worcester v. Georgia, 31 U.S. 515, $539-540$ (1832).
} 
Although it may not seem obvious, libertarian political philosophy actually provides the most comprehensive framework necessary for achieving the goal of tribal measured separatism. While many Indian law scholars approach the discipline from a communitarian perspective - one admirably influenced by the tribal traditions of community and sharing. Even Indian law's leading scholar, the University of Arizona's Robert A. Williams frames the question of Indian rights in terms of a measured separatism for tribal governments to manage their own affairs. In his book, Like a Loaded Weapon, Williams notes the departure point for building a new system of Indian rights must begin with a basic statement of what Indians are ultimately seeking amid the governmental power structures of the United States:

Ultimately, what Indians are seeking from the Court is something much different. They are arguing for a right to a degree of "measured separatism," that is, the right to govern their reservation homelands and those who enter them by their own laws, customs, and traditions, even when these might be incommensurable with the dominant society's values and ways of doing things. ${ }^{335}$

Williams's unique insight is in articulating and formulating a vision for Indian rights that reflects the institutional situation of all Indian tribes vis-à-vis the Federal and state governments. As he notes, quite unlike the civil rights struggle of the 1960s, which aimed at genuine integration and racial equality, ${ }^{336}$ Indian tribes ultimately are not seeking integration into the governmental structure but a freedom from government that will allow them to pen a meaningful new chapter in the experiment of government by the consent of the governed. Whereas the civil rights movement was about bringing minorities into the governmental structure through equality before the law, what Indian tribes ultimately want is to be left alone.

I should add from the outset, I understand the potential skepticism of my audience. I expect that readers from Indian Country and libertarian quarters alike will question my very

\footnotetext{
${ }^{335}$ Williams, supra $\mathrm{n} .7$ at $\mathrm{xxxv}$.

${ }^{336}$ Id.
} 
premise, let alone whether my efforts are successful. Even so, I am reminded of the words of Solomon who observed that, "Iron sharpens Iron, and one man sharpens another." ${ }^{" 337}$ My hope is that the following discussion will demonstrate that both disciplines are rather sharp and useful irons, indeed.

\section{A. What Is Libertarianism?}

In 1997, the Cato Institute's David Boaz released a pivotal work in libertarian theory under the minimalist title Libertarianism: A Primer. ${ }^{338}$ Early in the book Boaz offers the following, succinct definition of libertarianism:

Libertarianism is the view that each person has the right to live his life in any way he chooses so long as he respects the equal rights of others. ${ }^{339}$

As libertarianism relates to government, Boaz argues that "governments should exist to protect rights, to protect us from others who might use force against us...thus libertarians condemn such government actions as censorship, the draft, price controls, confiscation of property and regulation of our personal and economic lives." 340

The key insight of Boaz's work is the way in which governmental power is perceived under a libertarian framework. Governments have a negative role in the articulation of rights, rather than a positive role, meaning that the function of government is to protect rights, not create them. Accordingly, libertarians tend to enumerate, and thereby limit, the powers of government, rather than leaving the exposition of rights to juridical interpretations that can provide for the powers of government to expand.

Regarding the individual, Boaz argues that the framework of libertarian philosophy places an emphasis on the individual as "the basic unit for social analysis," because only

\footnotetext{
${ }^{337}$ English Standard Version, Proverbs 27.17.

${ }^{338}$ David Boaz, Libertarianism: A Primer (Free Press 1997).

${ }^{339} I d$. at 2 .

${ }^{340} I d$.
} 
individuals are capable of choice. ${ }^{341}$ Similarly, only individuals can assume the concurrent obligation of choice, which is to take responsibility for one's personal decisions and actions. ${ }^{342}$

While this may seem counter to tribal notions of government which place an emphasis on community, Boaz distinguishes the ethical and normative respect of the individual that is the basis of libertarianism, from the free right of contract through social interaction that individuals routinely undertake as members of a free society. ${ }^{343}$ In fact, Boaz readily acknowledges the importance of community in forming the "complex and productive society" that we enjoy today - one that is made possible only by intricate interdependencies through "social interaction[s]." 344 Far from advocating the solitary life, Boaz's emphasis on individualism simply makes the point that human dignity is vested in singular persons, who also wield the right to freely associate with others.

Finally, Boaz views libertarianism and its utility through a pragmatic lens. Far from being a panacea for every conceivable social ill, Boaz cautions, "the libertarian approach to public policy should be seen not as a catechism but as a set of problem-solving techniques that can be applied to many problems. ${ }^{" 345}$ The notion of libertarianism as a set of analytical tools is a common theme among libertarian scholars, as we will soon see. For our present purposes, it is sufficient to observe that the goal is to construct a framework of principles for Indian rights in the U.S. that limits the power of the Federal Government, while maximizing the liberty interests of American Indians.

\footnotetext{
${ }^{341}$ Id. at 95.

${ }^{342} I d$.

${ }^{343}$ Id. at $96-97$

${ }^{344}$ Id.

${ }^{345} \mathrm{Id}$. at 210.
} 


\section{B. The Role of Government Within a Libertarian Framework}

To recap, libertarianism is the view that each person has the right to live life however one wishes provided that the individual assumes a concomitant respect for the equal rights of others. ${ }^{346}$ Naturally, this suggests a limited role for government within a society, and within Indian affairs, in particular, but this is far too vague to be left unaddressed. Fortunately, a number of scholars influenced by libertarian philosophical thought have provided insight into both questions. The following section explores the work of libertarian scholars Robert Nozick and Frederic Bastiat, and their conceptualizations of the ideal role of government within a state.

\section{Nozick's "Utopia" and Theory of Distributive Justice}

With the exception of Ayn Rand, no scholar in the modern era has been more instrumental in bringing libertarian philosophy to the fore of public consciousness than Robert Nozick. Even while Nozick's work is not the oldest account of libertarian ideals, it is by far the most systematic, providing not only a point of departure for analyzing the works of other theorists, but also laying a basic foundation of libertarian thought for all of the analysis that follows. What makes Nozick's work especially compelling is that, prior to his untimely death in 2002, his philosophical scholarship included a wide array of interests, ranging from epistemology to metaphysics. This breadth of knowledge enabled Nozick to approach philosophical theory in an extremely practical manner, allowing even relatively dense subject matter to become accessible. These qualities of readability and sophistication permeate Nozick's most famous work Anarchy, State, and Utopia. ${ }^{347}$

Proceeding in three parts, Nozick launches a staunch defense of the minimal state by first examining Locke's state of nature, "a state of perfect freedom," in order to better understand

\footnotetext{
${ }^{346}$ Boaz, supra n.338 at 2.

${ }^{347}$ Robert Nozick, Anarchy, State, and Utopia (Basic Books 1974).
} 
how a state might arise "naturally" in lieu of anarchy. ${ }^{348}$ As Nozick framed the matter, "The fundamental question of political philosophy, one that precedes questions about how the state should be organized is whether there should be any state at all. Why not have anarchy?"349 Despite the simplicity of the question, the answer is not obvious. Nozick spends roughly the next one hundred, or so, pages explaining why a minimal state would arise from a state of nature, calling it his "invisible-hand explanation" in a nod to Adam Smith. ${ }^{350}$

Nozick's explanation of the minimal state rests upon two, basic premises: 1) individuals possess rights, meaning that 2) they will invariably need to protect their rights from violation, which results in the self-interested formation of protective associations -in effect, minimal states. ${ }^{351}$ According to Nozick, this self-interested formation places the state in the "unique position" of being "the arbiter of correctness," determining what constitutes the breach of another's rights, and determining what repercussions result "for the purposes of punishment" in the enforcement of rights. ${ }^{352}$ This unique status gives the state a "de facto monopoly" over the enforcement of the rights of individuals. ${ }^{353}$ Under Nozick's model the minimal state's powers do not, and cannot extend morally beyond this. ${ }^{354}$

The second part of Nozick's work argues against a bevy of justifications for expanding the authority of the minimal state. ${ }^{355}$ As noted above, it comes as little surprise that Nozick rejects all of them forthrightly in the first line of the section: "The minimal state is the most extensive state that can be justified. Any state more extensive violates people's rights. ${ }^{" 356}$ Still,

\footnotetext{
${ }^{348}$ John Locke, Second Treatise of Government, Chapter II $\S 4$ (Hackett 1980).

${ }^{349}$ Nozick supra n.338 at 4.

${ }^{350}$ Id. at 118 .

${ }^{351} I d$.

${ }^{352} I d$.

${ }^{353} \mathrm{Id}$.

${ }^{354}$ Id. at 149.

${ }^{355} I d$. at $149-294$.

${ }^{356} \mathrm{Id}$. at 149
} 
Nozick's rejection is not indiscriminate. He addresses each weighty argument levied against the minimal state thoroughly, and often inductively, using both real life examples and even equations to communicate his point. ${ }^{357}$ While it is beyond the scope of this work to explore all of the arguments and counter arguments against the minimal state that Nozick considers, his normative discussion of distributive justice principles in a response to John Rawls' $A$ Theory of Justice $^{358}$ is important for the distinction it outlines between libertarian notions of justice, and those of communitarians, which will be evaluated later. More fundamentally, Nozick's ideas about justice in society are crucial to the eventual framework of a libertarian theory of Indian rights that will be developed. ${ }^{359}$

In brief, Nozick's vision of distributive justice in a libertarian, minimal state relies upon the following three main principles, and a "principle of rectification" triggered only in the event of a violative distribution:

1. A person who acquires a holding in accordance with the principle of justice in acquisition is entitled to that holding.

2. A person who acquires a holding in accordance with the principle of justice in transfer, from someone else entitled to the holding, is entitled to the holding.

3. No one is entitled to the holding except by (repeated) applications of 1 and $2 .{ }^{360}$ Under the first principle of distributive justice, Nozick explains that a distribution is considered just so long as it is obtained in a manner consistent with the principle of just acquisition -

\footnotetext{
${ }^{357}$ Nozick's critique of Rawls' Theory of Justice is particularly liberal in its use of inequality notation, making for an entertaining, if not convoluted read for many law students. (See Nozick supra n.347 at 211, and 183-231).

${ }^{358}$ See John Rawls, A Theory of Justice (Harvard U. Press 1971). For a lengthier discussion of Rawls, see Rawls, infra n.605 at 302.

${ }^{359}$ For some, it may be easier to understand the principles distributive justice as principles of redistribution although Nozick himself would doubtless reject this understanding as a perversion of his system. Broadly, distributive justice principles are defined as "normative principles designed to guide the allocation of the benefits and burdens of economic activity." See Standford Encyclopedia of Philosophy, "Distributive Justice," http://plato.stanford.edu/entries/justice-distributive/ (Accessed Nov. 22, 2011).

${ }^{360}$ Nozick, supra n.347 at 151.
} 
defined as "whatever [distribution] arises from a just situation by just steps is itself just." ${ }^{" 361}$ Under the second principle of distributive justice, a distribution obtained from someone else is considered just so long as it is consistent with the principle of just transfer - defined as obtaining a distribution through legitimate means (according to the principle of just acquisition), from someone who has also obtained the distribution through legitimate means (again according to the principle of just acquisition) ${ }^{362}$ The third principle is simply a reiteration that subsequent distributions must comport with principles one and two. In the event that a distribution violates any of the principles above, Nozick presumes that a "principle of rectification of injustice" would apply, drawing from "the historical information about the previous situations and injustices done," and the actual results that followed from the time the injustices were committed to the present. ${ }^{363}$ In the event that a distribution is found to violate one of the three principles, then the violation must be corrected in a manner consistent with the principles of distributive justice. ${ }^{364}$

Finally, the third part of Nozick's work details his vision of "utopia," a thoroughly tongue-in-cheek word used to describe his framework for the ideal libertarian state ${ }^{365}$ Insofar as visions of utopia can be, Nozick's utopia is realistic. Unlike the stereotypes of philosophers dreaming grand, obtuse dreams, Nozick candidly confesses that he does not believe his vision is possible, and readily describes it as a "fantasy." ${ }^{"} 66$ The point of Nozick's exploration, then, is not to implement a single utopia that would "simultaneously and continually...realize all social and political goods. ${ }^{367}$ In fact, given his model of the minimal state, it would be impossible for such

${ }^{361} I d$.

${ }^{362} \mathrm{Id}$.

${ }^{363} \mathrm{Id}$. at 152

${ }^{364} \mathrm{Id}$. at 153 .

${ }^{365} \mathrm{Id}$. at 297.

${ }^{366} \mathrm{Id}$. at 308.

${ }^{367}$ Id. at 302 . 
a vision to be implemented at all given that the minimal state lacks a coercive mechanism for implementing mass social change. Instead, the point of Nozick's exploration of utopia is to introduce a model for social change that is both diverse and incremental, allowing for the creation of a plethora of utopias mirroring "the economists' model of a competitive market." 368 Nozick's model envisions a multitude of communities, "which people can enter if they are admitted, leave if they wish to, shape according to their wishes; a society in which utopian experimentation can be tried, different styles of life can be lived, and alternative visions of the good can be individually or jointly pursued." ${ }^{369}$ To say the least, this structure fundamentally sets Nozick's framework apart from competing visions of the state in political philosophy. Rather than implement social change on a macro level, Nozick's model analyzes society on a micro level and assumes that communities will form on the basis of like interests, through the choices of "rational agents." 370

After laying out his framework, Nozick anticipates challenges to his model, and readily admits that not only that it is impracticable to satisfy all of the possible communities that individuals might want (a condition presumed true under his original framework) but also that it may not be wise "should we try to satisfy each." ${ }^{371}$ The fundamental problem Nozick confronts in constructing his libertarian utopias model is the simple reality that "people are different" so there cannot be "one community which will serve as ideal for all people and much reason to think that there is not." ${ }^{\prime 72}$ By tempering his libertarian model, the crux of Nozick's framework becomes its voluntary nature. While voluntary association may not create a utopia for each person, the utopia of utopias model allows for a "filtering process" that provides for the modification, elimination,

\footnotetext{
${ }^{368} \mathrm{Id}$.

${ }^{369} \mathrm{Id}$. at 307.

${ }^{370} \mathrm{Id}$. at 306.

${ }^{371} \mathrm{Id}$. at 308 .

${ }^{372} \mathrm{Id}$. at $309-310$.
} 
or abandonment of communities based upon the desires of community members - not the whims of an overarching central power. ${ }^{373}$ As individuals implement various ideas for improving the community according to their own desires, the model also allows for new ideas of governance to emerge, creating a self-sustaining climate for innovation and change based upon the desires of the community. ${ }^{374}$

One additional criticism that Nozick anticipates is his unsatisfactory treatment of the central authority of the minimal state. ${ }^{375} \mathrm{He}$ expressly indicates that his model does not provide insight into the process for selecting the authority, the form it should take, or the means for ensuring that its role does not exceed the minimal state's basic design. ${ }^{376}$ In a different context, such omissions might be regarded as fatal flaws. But within Nozick's libertarian framework, the oversights are doubtless strengths of the system. Nozick's personal conclusion of the matter is that "it seems desirable that one not be fixed permanently but that room be left for improvements of detail." To state matters differently and in true libertarian fashion, the function of the central authority should be a choice left to the members of each minimal state to decide. ${ }^{377}$ To this end, Nozick concedes "the messiness of the details of political apparatus, and the details of how it is to be controlled and limited do not fit easily into one's hopes for a sleek, simple utopian scheme." ${ }^{378}$

\section{The Influence of Bastiat on the Metes and Bounds of Government}

While Nozick was able to successfully establish a framework for the ideal, libertarian state, his thinking was inspired by the work of a number of philosophers dating back to the Age

\footnotetext{
${ }^{373} I d$. at 316.

${ }^{374}$ Id. at 317.

${ }^{375} \mathrm{Id}$. at 329.

${ }^{376} \mathrm{Id}$. at $329-330$.

${ }^{377}$ Id. at 330.

${ }^{378}$ Id.
} 
of Enlightenment. One philosopher who did much to inform libertarian thought about the role of government in society was the $19^{\text {th }}$ century economist and philosopher Frederic Bastiat. Written on the heels of the French Revolution of 1789, and in the middle of the European Revolutions of 1848, Bastiat's pamphlet on The Law provided a concise argument for the rule of law in a free society, even while insurrection and rebellion once again ravaged the streets of Paris. ${ }^{379}$ The result is a striking narrative about liberty borne from adversity that has endured for Bastiat's elegance and clarity.

Like many of his contemporaries, Bastiat begins his examination of the law with a discourse on the nature and origins of rights, arguing that "life, liberty, and property" are extant gifts of the Divine, existing in spite of, and instead of "human legislation, and are [even] superior to it." ${ }^{380}$ The result is that law merely serves a "negative" function, existing to prevent injustices (defined as injuries to rights), from occurring. ${ }^{381}$ Similar to Nozick's utopia, the role of government within a free society is a limited one under Bastiat's framework. Even as Bastiat proscribes individuals from using force against another's life, liberty, or property, so too is a government barred from using force against the same, absent the necessity of maintaining rights, and ensuring justice. ${ }^{382}$

Like Nozick, Bastiat is a realist about the potential for his scheme of rights and government. Writing in 1850 , he notes "law by no means confines itself to its proper functions," but tends to exceed its scope on a regular basis due to both "stupid greed and false philanthropy." ${ }^{\prime 83}$ Where greed is the motivation, Bastiat calls the encroachment "lawful plunder," which he defines as manipulating the law to seize the property of a plundered class, or using

\footnotetext{
${ }^{379}$ Frederic Bastiat, The Law (Foundation for Economic Education 1998).

${ }^{380} \mathrm{Id}$. at 1 .

${ }^{381} \mathrm{Id}$. at 25.

${ }^{382} \mathrm{Id}$. at $2-3$.

${ }^{383}$ Id. at $4-5$.
} 
government to violate an individuals' right of property. ${ }^{384}$ The result of legal plunder under Bastiat's framework is that it forms a new epistemology, erasing "from everyone's conscience the distinction between justice and injustice." ${ }^{385}$ The enduring effect of this new theory of legal plunder is that it distorts its moral origins, and allows individuals to "erroneously" come to believe that "anything lawful is also legitimate" merely because the "law makes them so." 386 Bastiat's solution is the immediate abolishment of all laws permitting legal plunder, identifying such measures as any that "take from some persons what belongs to them and gives it to other persons to whom it does not belong." 387

Where law exceeds its narrow role of guarding against injustices, and the motivation is philanthropy, Bastiat makes no distinction between charitable aims and selfish aims, dubbing philanthropic takings "plunder" as well. ${ }^{388}$ Bastiat argues that using the coercive force of law to accomplish philanthropic objectives, such as the organization of "labor, education, and religion," nonetheless, diminishes the liberty of individuals because it acts "positively upon people," substituting the will of the person for the will of government. ${ }^{389}$ This outcome is anathema to Bastiat's system, which envisions the rule of law and the role of government as imposing nothing more on individuals than a mere negation - the simple maxim that individuals abstain from harming the rights of others. ${ }^{390}$ Any other acts of law, or the use of force by governments constitute a violation of an individual's life, liberty, or property under Bastiat's framework. ${ }^{391}$

Finally, like Nozick, Bastiat also anticipated the arguments of critics against his vision of the state. Having more or less confined his discussion of legal plunder motivated by greed to the

\footnotetext{
${ }^{384} I d$. at 7.

${ }^{385} \mathrm{Id}$. at 8 .

${ }^{386} I d$. at 9.

${ }^{387}$ Id. at 17.

${ }^{388}$ Id. at 24.

${ }^{389} I$ d. at 25.

${ }^{390} \mathrm{Id}$.

${ }^{391} \mathrm{Id}$. at 26.
} 
first section of his work, the final pages of Bastiat's pamphlet again take up the topic of legal plunder motivated by philanthropy. Rather than restate his position, Bastiat instead walks through the various arguments lobbed in opposition to his system, and in support of socialism, despotism, and the monarchy - all very real topics of debate in 1850 s France. ${ }^{392}$ Of course, Bastiat summarily dismisses each one as a perversion of the rule of law, but his writing indicates a unique concern over philanthropic arguments for expanding the powers of the state - the section reads as if Bastiat himself consider these arguments the most damaging to his system. ${ }^{393}$ Accordingly, he attacks with a renewed vigor, calling such governmental interventions "philanthropic tyranny" aimed at obliging individuals to bear the "yoke of public welfare." ${ }^{394}$ Of his opponents, Bastiat frames them as nothing more than the "heads" of famous men, "subjecting mankind to philanthropic tyranny of their own social inventions." 395

While Bastiat's language may seem fairly innocent today, his use of the term 'tyranny' carried a much greater cachet in 1850 than it does now. Using the loaded term not only allowed Bastiat to associate his adversaries with the nemesis of French revolutionaries, but it also allowed Bastiat to reframe the debate as being one against the imposition of force on the will of individuals. ${ }^{396}$ The result is that Bastiat escapes arguing against the various social programs that were being discussed in the French Assembly, while forcing his opponents to defend their legislative violations of life, liberty, and property.

\section{The Role of Freedom in Securing Rights}

From Boaz's definition of libertarianism, to Nozick's minimal state, to Bastiat's negative view of law, all three suggest that freedom plays a dual role in both securing rights, and 
protecting against the encroachment of government upon the rights of individuals. But the exact content of freedom, and the role it should serve within the apparatus of government and society has been explored in only a limited manner. The following analysis of the role of freedom in securing rights draws from the works of three philosophers who each add a unique a perspective on freedom and its antithesis, coercion.

\section{Hayek On Liberty and Coercion}

Austrian scholar F.A. Hayek has long been considered among the most distinguished intellectuals in the fields of political philosophy and economics. A U.S. Presidential Medal of Freedom recipient, and winner of the Nobel Prize in Economics, aside from his expertise in macroeconomic theory and its effect on political and social processes, Hayek's work focused extensively on the ethical foundations of a free society, and the normative role of liberty as a source of moral values. ${ }^{397}$ His 1960 classic The Constitution of Liberty provides an expansive three-part discussion on the desirability and definition of liberty, the institutions that help to secure individual liberty, and the specific challenges to liberty in the realms of economic and social policy. ${ }^{398}$ Like the scholars discussed above, Hayek is a philosophical realist, declaring that his work is not to "provide a detailed program of policy, but rather to state the criteria by which particular measures must be judged if they are to fit into a regime of freedom." ${ }^{\prime 399}$

In Part I, Hayek's obligation is to arrive at a concrete definition of liberty that enables him to further explore its normative implications for society. He defines liberty as "the condition of men in which coercion of some by others is reduced as much as is possible in society. ${ }^{" 400}$ This may seem like a fairly modest goal, particularly in light of Bastiat's railings against

\footnotetext{
${ }^{397}$ F.A. Hayek, The Constitution of Liberty, 5 (U. Chicago Press 1978).

${ }^{398}$ Id.

${ }^{399} \mathrm{Id}$.

${ }^{400}$ Id. at 11.
} 
"philanthropic tyranny." ${ }^{401}$ But the objective is nonetheless consistent with Hayek's background as an economist and a policy pragmatist. Even as Hayek seeks a general state of freedom for society, he readily admits that this state is one that "his fellows may hope to approach closely, but can hardly expect to realize perfectly." ${ }^{" 402}$ Hayek's objective is not to conjure up mandates for social change, but to simply influence the discussion and minimize what he views as the harmful effects of coercion..$^{403}$ The limited application of Hayek's goal is further reflected in his definition of freedom. Hayek remarks that freedom "refers solely to a relation of men to other men, and the only infringement on it is coercion by men." ${ }^{404}$ Like Bastiat's conception of law, for Hayek, the matter of freedom is fundamentally negative, realized only through "the absence of a particular obstacle - coercion by other men." ${ }^{405}$ Hayek's role of freedom in society is not the assurance of a particular outcome, but the opportunity for individuals "to decide what use we shall make of the circumstances in which we find ourselves." ${ }^{" 406}$

Regarding coercion, Hayek defines the term in a similarly circumscribed manner.

Coercion is the "control of the environment or circumstances of a person by another that, in order to avoid greater evil, he is forced to act not in according to a coherent plan of his own, but to serve the ends of another." ${ }^{407}$ Under this definition, Hayek's great trepidation with coercion is the role that force plays in obliging individuals to act. In contrast to his state of freedom, Hayek's coercive society forces individuals to choose the lesser of evils - compliance, or punishment -

\footnotetext{
${ }^{401}$ Bastiat, supra n.379 at 52.

${ }^{402}$ Hayek, supra n.397 at 12.

${ }^{403} \mathrm{Id}$.

${ }^{404} I d$.

${ }^{405} \mathrm{Id}$. at 19.

${ }^{406} \mathrm{Id}$.

${ }^{407}$ Id. at $20-21$.
} 
which, "thus eliminates an individual as a thinking and valuing person and makes him a bare tool in the achievement of the ends of another." ${ }^{408}$

Even while his language is unequivocal in using the word evil to describe coercion, Hayek, nonetheless, concedes that coercion "cannot be altogether avoided, because the only way to prevent it is by the threat of coercion." ${ }^{409}$ Still, Hayek counters that free societies confer this "monopoly of coercion on the state," in an effort to restrict its power to those of protecting the private spheres of individuals, and those of "creating conditions under which the individual can determine his own sphere by relying on rules which tell him what the government will do in different situations." ${ }^{410}$ Hayek's vision sees a government's use of coercion "reduced to a minimum," as seldom as possible, and as made express through the rule of law. ${ }^{411}$

In making his case for freedom, Hayek also attempts to counter his critics and those supporting an expansive vision of the role of the state in society, noting that such political theories generally assume "that most individuals are very ignorant." ${ }^{, 412}$ By contrast, Hayek argues that even while individuals may be ignorant, they must also be counted among the wise in that the lot falls on each person to "make the best of use of what knowledge we have," in making decisions. ${ }^{413}$ Hayek's counter to his critics harkens to the basis of Nozick's vision of utopia. Formulating social policies imposes a one-size-fits-all rule that presupposes the omniscience of the rule maker in determining what is best for "the whole of society." ${ }^{\prime 14}$ The problem with this approach as both Nozick and Hayek demonstrate is that no individual wields the omniscience necessary to appropriately determine society's present needs, its future needs, or its needs when

\footnotetext{
${ }^{408}$ Id. at 21.

${ }^{409} \mathrm{Id}$.

${ }^{410} \mathrm{Id}$.

${ }^{411}$ Id.

${ }^{412} \mathrm{Id}$. at 30.

${ }_{413} \mathrm{Id}$.

${ }^{414} I d$. at 28.
} 
unforeseeable events to occur. ${ }^{415}$ In Hayek's system, liberty becomes the essential foundation and solution for society, because it is the only value that will "leave room for the unforeseeable and unpredictable" in the lives of individuals. ${ }^{416}$ Rather than viewing the condition of unpredictability resulting from freedom as a social ill, Hayek argues that freedom is the only state that can foster social progress, innovation, and personal improvement, allowing for individuals to take advantage of their ideas. ${ }^{417}$ To Hayek, any other system would merely stifle an individual's creative capacity.

Even while Hayek's vision would maximize individual liberty, this is not to say that Hayek is an anarchist in constructing his model of the free society. Hayek's vision provides a definitive place for the role of government and its institutions. ${ }^{418}$ As noted above, Hayek's view of governments is that they should reduce the role of coercion in society as much as possible..$^{419}$ Similarly, Hayek viewed government institutions as playing a key role in the reduction of coercion by providing society with a broad access to information so that they can "make use of this knowledge in their actions. ${ }^{, 420}$ Putting to rest any further accusation of anarchy, Hayek adds that the argument for liberty is really an argument for institutions that can serve as "one of the most powerful means that human reason can employ" - so long as the institutions and organizations are voluntary. ${ }^{421} \mathrm{He}$ further adds that some coercive actions by the state are, in fact, unavoidable - such as taxation and compulsory military service. ${ }^{422}$ But these coercive acts are justified in that they are predictable. ${ }^{423}$ Hayek cites the greatest threat to liberty as being those

\footnotetext{
${ }^{415} I d$. at 29

${ }^{416} I d$.

${ }^{417} \mathrm{Id}$. at 30

${ }^{418} \mathrm{Id}$.

${ }^{419}$ Id. at 21.

${ }^{420}$ Id. at 30.

${ }^{421}$ Id. at 37

${ }_{422}$ Id. at 143 .

${ }^{423}$ Id.
} 
coercive acts of the state that are neither avoidable, nor predictable because they remove any opportunity for individuals to shape their life independent of the will of the state. ${ }^{424}$

\section{John Locke's View of Power and Title}

John Locke's contributions to philosophy and political science cannot be understated. In many ways, Locke's Second Treatise of Government is the inspiration of each political philosopher discussed so far, and of each philosopher to be discussed hereafter - including the works of Adam Smith. ${ }^{425}$ It helps that Locke's work is very old, penned during the heart of the Age of Enlightenment in 1689. But this fact also speaks to its prescience. That so many of Locke's ideas have been incorporated into modern constitutional structures and the works of later philosophers make the Second Treatise of Government classic reading for anyone interested in political theory and law. Like Bastiat's pamphlet The Law, Locke's Second Treatise, is a relatively brief work, consisting of only 19 chapters, totaling just over 100 pages with some 243 sections. While it is not beneficial to explore each chapter of Locke's work, the following analysis will explore Locke's general views of freedom and the ways in which freedom secures rights in keeping with the theme of this section.

Locke's examination of freedom begins with his analysis of the state of nature. ${ }^{426} \mathrm{His}$ basic thesis is that "all men are naturally in... a state of perfect freedom to order their actions, and dispose of their possessions and persons, as they think fit, within the bounds of the law of nature, without asking leave or depending upon the will of any other man. ${ }^{4427}$ Locke's state of nature also assumes equality among individuals, which imposes a basic prohibition against harming the

\footnotetext{
${ }^{424}$ Id.

${ }^{425}$ Locke, supra n.221 at 7.

${ }^{426} I d$. at 8 .

${ }^{427}$ Id.
} 
"life, health, liberty, or possessions" of another. ${ }^{428}$ When violations of this "law of nature" occur, Individuals in the state of nature wield the right to exercise the executive power, including punishment for crimes and taking reparations for injuries. ${ }^{429}$

In Locke's view, the state of nature is not altogether desirable given the complexities of society and governance. But individuals can only leave the state of nature once they have subordinated their right to exercise their executive powers to the state, thereby "forming a common-wealth. ${ }^{" 430}$ The commonwealth must then establish a legislature to make laws on behalf of its members, and also a judicial authority "to determine all the controversies, and redress the injuries" that will invariably beset the commonwealth's members. ${ }^{431}$ The purpose for individuals relinquishing the state of nature for government, despite the comparative freedom of the former, is the common interest of protection, or as Locke puts it the "mutual preservation of their lives, liberties and estates, which I call by the general name property." ${ }^{\prime 42}$ This places Locke's view of government very much in line with the views of Hayek, Bastiat, and Nozick - or to be more precise, their views of government align with Locke's given that his treatise is by far the oldest, and most influential.

That Locke was no friend of centralized authority was further evident in his skepticism of plenary power generally. Regarding absolute monarchs, Locke wrote, "Hence it is evident, that the absolute monarchy, which by some men is counted the only government in the world, is indeed inconsistent with civil society, and so can be no form of civil government at all." ${ }^{{ }^{433}}$ of plenary power, Locke treated the concept with particular disgust declaring, "for he that thinks

\footnotetext{
${ }^{428}$ Id. at $8-9$.

${ }^{429} \mathrm{Id}$. at 12.

${ }^{430}$ Id. at 48 .

${ }^{431} I d$.

${ }^{432} I d$. at 66.

${ }^{433}$ Id. at 48.
} 
absolute power purifies men's blood, and corrects the baseness of human nature need read but the history of this, or any other age, to be convinced of the contrary." ${ }^{\prime 44}$ Today, this statement of power seems obvious, but the revolutionary nature of Locke's view should not be underestimated. Even as Locke penned early drafts of his Second Treatise, England's King James II argued for the divine right of kings, and an absolute monarchy, leading to stiff resistance among both the political and intellectual elite. ${ }^{435}$ The unrest eventually culminated in the Whig Revolution of 1688, the deposition of King James II, and ascent of William and Mary to the throne. ${ }^{436}$ By the time Parliament passed the Hanoverian succession in 1701, Locke's treatise and its view of governmental power had been used to both weaken the monarchy, and increase the power of Parliament. ${ }^{437}$

Given Locke's view of plenary power, it is notable that he also wielded a similar disdain for a right to govern by conquest. Locke argued at length that governments are only legitimate when they are founded with "the consent of the people," observing that the mere act of conquest itself is insufficient for "setting up any government." ${ }^{, 438}$ Locke likened the notion of government by conquest to the act of a robber invading an individual's home, rhetorically asking whether a robber's demand for the deed to the estate actually gave him just title. ${ }^{439}$ Completing the analogy, Locke concludes, "Just such a title, by his sword, has an unjust conqueror, who forces me into submissions." $\$ 440$

While it is tempting to suggest that Locke's view was a limited one, reserved for unjust conquerors only, Locke writes elsewhere against the right of government by conquest in a

${ }^{434}$ Id. at 49.

${ }^{435} I d$. at $\mathrm{xxi}$.

${ }^{436} \mathrm{Id}$.

${ }^{437}$ Id.

${ }^{438} \mathrm{Id}$. at 91.

${ }^{439} \mathrm{Id}$.

${ }^{440} \mathrm{Id}$. 
broader sense. Discussing the double birthright of all human beings (the right of freedom, and the right of inheritance), ${ }^{441}$ Locke argues that when "the inhabitants of any country, who are descended, and derive a title to their estates from those who are subdued," the inhabitants "retain a right to the possession of their ancestors" because the conqueror never had title to the land. ${ }^{442}$ Elsewhere, Locke argues even more broadly that "persons are free by a native right, and their properties....are their own, and at their own dispose, and not at his [the conquering power]; or else it is no property." ${ }^{, 43}$ When Locke's view of government by conquest is taken together with his view of the monarchy, his state of nature, and the centrality of freedom within his vision of the ideal commonwealth, it is remarkable that Locke's work is eminently consistent with the Libertarian tradition of limited government that has followed some 300 years later.

\section{Popper's Defense of the Open Society and a Critique of Nationalism}

Any analysis of freedom and its role in securing individual rights would be surely amiss without noting the contributions of British philosopher and economist, Karl Popper. Although he wrote extensively about such sundry topics as the falsifiability of scientific laws, historicism, and epistemology, he is, perhaps, most famous for his defense of democracy in the two-volume work The Open Society and Its Enemies. Written during the height of World War II, Popper's lengthy work sought to combat intellectual origins of totalitarianism, even as war raged in Europe. ${ }^{444}$ The product that followed was a macro-level demonstration of the danger of social engineering schemes wrought by the arrogant hand of centralized power. ${ }^{445}$ The entire, two-volume set proceeds in some eleven parts, consisting of 25 chapters in total. The first volume generally deals with the origins of Plato's Republic, demonstrating the ways in which historicism has inspired

\footnotetext{
441 Id. at 98 .

${ }^{442} I d$.

${ }^{443}$ Id. at 99.

${ }^{444}$ Karl R. Popper, The Open Society and Its Enemies 1, vii (Princeton U. Press 1966).

${ }^{445} \mathrm{Id}$.
} 
totalitarian actions, and the dangers implicit in the ancient philosopher's work. ${ }^{446}$ The second volume uses Popper's interpretation of Plato to analyze the works of Hegel and Marx, offering a warning against the reification of history, and the importance of freedom in thwarting pursuits of unbridled power. ${ }^{447}$

Although he repeatedly denies it, Popper's colossal work follows like a history of historicism. ${ }^{448}$ As such, much of his philosophical analysis of historicism largely falls outside the scope of the present examination. Still, Popper's aim was to combat the intellectual origins of totalitarianism, by juxtaposing "the Platonic theory of justice and the theory and practice of modern totalitarianism. ${ }^{" 449}$ In doing so, Popper advanced a number of arguments highlighting the importance of freedom in the open society that are instructive for understanding the role of freedom in securing rights generally. One of Popper's more interesting arguments comes in his discussion of leadership, found in chapter seven, of volume one. After briefly discussing Plato's explanation of the problem of politics, Popper remarks that Plato's entire inquiry is rooted in the tacit assumption that power is essentially unchecked. ${ }^{450} \mathrm{He}$ also finds elements of this view among modern scholars debating "who should dictate? The capitalists or the workers?" ${ }^{451}$ Despite the acceptance of Plato's premise, Popper does not view this as an accurate point of departure. Empirically, Popper notes that the premise of plenary power is a myth since even the most extreme tyrant requires the aid of agencies, "secret police," and a bevy of institutional controls. $^{452}$

\footnotetext{
${ }^{446}$ Id. at 169.

${ }^{447}$ Karl Popper, The Open Society and Its Enemies Vol. 2, 269 (Princeton U. Press 1966).

${ }^{448}$ Id. at 259.

${ }^{449}$ Popper, supra n.444 at 5.

${ }^{450} \mathrm{Id}$. at 121 .

${ }^{451} I$ d.

${ }^{452}$ Id. at $121-122$.
} 
Still, Popper's main argument is that the open society must harness plenary power through the implementation of "institutional control of rulers by balancing their powers against powers," or to state matters simply Popper's is a "theory of checks and balances." ${ }^{453}$ The democratic nature of Popper's theory is of central importance to his model. Popper argues that democracy itself is a check of sorts on society, providing "the institutional framework for the reform of political institutions." ${ }^{\text {454 }}$ Because "institutions cannot reform themselves," free people living within the democratic state must improve problems through the institutional mechanisms of democratic governance. ${ }^{455}$ Thus, free people have no one but themselves to blame when problems arise since they are the guardians of their own rights. ${ }^{456}$

The operation of Popper's democratic state is explored later in the work in his biting critique of "utopian" social engineering. ${ }^{457}$ Rather than implementing a grand programmatic blueprint for society, Popper suggest that government and its leaders opt for "piecemeal engineering," to fight "the greatest and most urgent evils of society, rather than searching for, and fighting for, its greatest ultimate good." ${ }^{458}$ The differences between the two, and their implications for freedom are stark. According to Popper, utopian social engineering is impracticable simply because no one wields the requisite judgment to implement a blueprint for all of social life. ${ }^{459}$ This renders the quest for "an ideal society" all but dead on arrival. Popper's pragmatic alternative is to seek and implement singular, programmatic blueprints for extant institutions across society. ${ }^{460}$ Should a plan go awry within a single department or institution,

\footnotetext{
${ }^{453} \mathrm{Id}$. at 122 .

${ }^{454}$ Id. at 126.

${ }^{455}$ Id. at 127.

${ }^{456} I d$.

${ }^{457} \mathrm{Id}$. at 158 .

${ }^{458} \mathrm{Id}$.

${ }^{459} \mathrm{Id}$. at 159.

${ }^{460} I d$.
} 
"damage is not very great, and re-adjustment not very difficult."461 This makes such plans, or legislation, politically less risky, and less controversial. ${ }^{462}$

By contrast, sweeping, utopian measures of social engineering tend to result in the centralized rule of a few, causing a corresponding reduction in freedom, and even leading to dictatorship. ${ }^{463}$ Popper notes that large-scale social reforms tend to be so large that the undertakings require "considerable inconvenience to many, for a considerable span of time."464 Given the inevitability of complaints, leaders are obliged to suppress criticism - whether legitimate or unfounded. ${ }^{465}$ Naturally, such suppression is inconsistent with the type of open, free society that Popper would construct. Similarly, assuming the adoption of a large-scale, utopian reform, the political aim may break down over time as ideas, ideals, and political whimsy change. ${ }^{466}$ All of these potential drawbacks lead Popper to conclude that such sweeping changes are wholly undesirable given the alternative, piecemeal social engineering scheme he recommends. ${ }^{467}$

In Popper's second volume, his line of inquiry continues in very much the same manner as his preceding volume, examining the works of philosophers in hopes of understanding how historicism influenced the unfolding reign of totalitarianism sweeping World War II-era Europe. In his discussion of Hegel's "Platonizing worship of the state," and "radical collectivism," "468 Popper openly questions Hegel's principle of the national state or nationalism, which he defines as "the political demand that the territory of every state should coincide with the territory

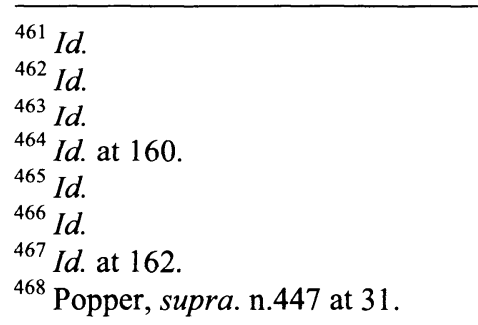


inhabited by one nation." ${ }^{\$ 49}$ Popper takes issue with the widespread adoption of Hegelian nationalism, wondering about its utility as a fundamental political category - as opposed to, say, birth in a certain geographic area, dynastic loyalty, political creed, or even religion. ${ }^{470}$ Ultimately, Popper concludes that Hegel was simply mistaken - that the principle of the national state is inapplicable, ill conceived, and an irrational, romantic myth. ${ }^{471}$

Popper's concern with nationalism's influence stems from its relationship to reason and freedom. ${ }^{472}$ In Popper's view, modern totalitarianism as influenced by Hegelian nationalism is a threat to freedom in that it cultivates the idea that "the state is the law, the moral law as well as the juridical law," and as such it is not "subject to any other standards, and especially not to the yardstick of civil morality. ${ }^{" 473}$ As the arbiter of all that is good, the state's interest lies in its own expansion, rejecting any judge but the historical success of its ventures, and eclipsing all other considerations - including the private rights of individuals. ${ }^{474}$

\section{The Role of the Market in Preserving Freedom}

Our discussion to this point has had three objectives. The first section sought to briefly arrive at a definition of libertarianism, distilling the work of Boaz who explains the manifold elements of libertarian philosophy in much greater detail. The second portion examined the role of the state within a libertarian framework of rights, exploring the works of Nozick who is widely regarded for his construction of the libertarian's ideal state, and Bastiat who emphasized the need for individual rights vis-à-vis the state. The previous section discussed the importance of freedom in securing individual rights, drawing from the likes of Hayek, Locke and Popper.

\footnotetext{
${ }^{469}$ Id. at 51.

${ }^{470} I d$.

${ }^{471} I d$.

472 Id. at 60.

${ }^{473} \mathrm{Id}$. at 66

${ }^{474} I d$.
} 
What follows is the final section of the libertarian framework of rights. Libertarian scholars have consistently emphasized the role of markets in preserving human freedom, creativity, and in promoting voluntary exchange among individuals. This section explores the major themes of five philosophers and economists: Adam Smith, Milton Friedman, Thomas Sowell, Hernando De Soto, and Ayn Rand. All of these scholars are renown for their commitment to free markets and voluntary exchange.

\section{Adam Smith on Free Markets and Free Societies}

Adam Smith's colossal work, commonly dubbed The Wealth of Nations, is largely considered to be the foundation of classical economic theory. ${ }^{475}$ There, Smith's primary concern was in combating mercantilist preoccupations with the transfer of wealth, promoting an alternative theory that was concerned with the creation of wealth in a service-based economy buttressed by a robust division of labor. ${ }^{476}$ Unlike some philosophers, Smith forthrightly states his basic thesis in the opening pages of The Wealth of Nations:

The greatest improvement in the productive powers of labour, and the greater part of skill, dexterity, and judgment with which it is any where directed, or applied, seem to have been the effects of the division of labor. ${ }^{477}$

After stating the importance of the division of labor, Smith follows this with his now classic example of the pin-maker. Assuming a workman of little education and skill in machinery, an individual could at best make one pin per day. ${ }^{478}$ Yet, when a manufacturer divided the manner of production over a number of workers, each with a specific skill (one "draws out the wire," one straightens it, etc.), the number of pins produced could increase dramatically - in Smith's

\footnotetext{
${ }^{475}$ See Thomas Sowell, Basic Economics, 622 (Basic Books 2010).

${ }^{476}$ Id. at 621 .

${ }^{477}$ Adam Smith, An Inquiry Into the Nature and Causes of the Wealth of Nations, 9 (Harvard Classics 1988).

${ }^{478}$ Id. at 10.
} 
example ten workers could produce upwards of twelve pounds of pins per day, or around 4,000 pins in total. ${ }^{479}$

While Smith's division of labor may seem intuitive in our day of mass communication and globalization, where products frequently rely upon the skill of workers from within the same factory and from the skill of workers from around the world, the idea was relatively novel when it was published in 1776. The chief benefit Smith foresaw of his division of labor was "the great multiplication of the productions of all the different arts," allowing wealth to permeate a "wellgoverned society," including the "lowest ranks of the people." 480 Smith saw that the division of labor as a pathway to wealth for society generally, rather than for the exporter only; one that allowed even the most unskilled worker to utilize an innate ability to perform meaningful work beyond providing merely for one's own subsistence. ${ }^{481}$

Crucial to Smith's division of labor is his thesis about its origins. Far from the product of a command-control economy, Smith championed the free market, noting "it is not from the benevolence of the butcher, the brewer or the baker, that we expect our dinner, but from their regard for their own interests. ${ }^{\$ 42}$ Rather than forcing individuals to produce goods, Smith's market envisioned individuals producing services in the form of goods for a profit, thus multiplying production across society and maximizing opportunities for nations to accumulate wealth on a per capita basis. This expansive view of voluntary exchange is further evident in Smith's perception of individual self-interest as a universal virtue shared among humanity. He famously decried the institution of slavery for its inefficiency and moral repugnance, while

\footnotetext{
${ }^{479} I d$.

${ }^{480}$ Id. at 15.

${ }^{481} \mathrm{Id}$. at 16.

${ }^{482}$ Id. at 19.
} 
finding examples of self-interested production and the division of labor among the tribes of American Indians in the U.S. ${ }^{483}$

Smith explains, much later in the work, that the wealth of nations comes from exactly this system of voluntary exchange, as opposed to a nation's annual exports - the dominant economic policy of mercantilism. Accordingly, Smith argued that a nation's annual revenue is equal to the value of its entire domestic production, thereby giving workers an incentive to maximize their own self-interest, using their skills for the sake of profit, and the incidental, but not inconsequential benefit of the entire domestic economy ${ }^{484}$ Even so, this "support of domestic industry" is functionally important to workers only insofar as they provide for their own security - or the maximization of their own gain. ${ }^{485}$ In Smith's scheme, workers are led by the famous "invisible hand to promote an end which was no part of his intention," the social good. ${ }^{486}$ Yet, the incidental benefits of production that society reaps through an increased GDP has the effect of providing social benefits even more effectively than compulsory systems requiring societal promotion at the expense of producers. ${ }^{487}$

It is worth noting that while Adam Smith has been championed as the conservative's conservative, he was no radical. Smith did, indeed, advocate for a society as free as possible one promoting "natural liberty" in such a way that all individuals are free to pursue their own interest in their own way, and to bring their talents into the competitive market with other individuals. ${ }^{488}$ But he was not opposed to governmental institutions per se. While Smith saw no role for governments in interfering with the operation of the economy - he dismissed such

\footnotetext{
483 Id. at 20.

${ }^{484} \mathrm{Id}$. at 335 .

${ }^{485} \mathrm{Id}$.

${ }^{486} \mathrm{Id}$.

${ }^{487}$ Id.

${ }^{488} I d$. at 445 .
} 
actions as delusional, requiring both knowledge and "performance of which no human wisdom or knowledge could ever be sufficient" - he, nonetheless, envisioned a three-fold role for government within the society: defending it from violence, guarding it against injustice and oppression, and establishing public institutions for the benefit of society in the aggregate. ${ }^{489}$

On the other hand, Smith's reputation among libertarians remains strong, not only for his views of voluntary exchange, and the free society, but also for his view of taxation. Smith's basic thesis can be summed up in his principles of taxation, outlined toward the end of his work. In brief, Smith argues that taxes should be structured "both to take out and to keep out of the pockets of people as little as possible, over and above what it brings into the public treasury of the state. ${ }^{{ }^{490}}$ In particular, Smith raised four concerns about the state implementation taxation schemes. First, he was concerned about the construction of massive bureaucracies necessary to collect taxes; Second, Smith worried about the potential for over taxation to discourage individuals from entering into industry at all; Third, Smith saw the potential of high taxes to ruin individuals who might fall on hard times and run afoul of the dreaded tax man (leading either illegal tax evasion, or the potential to deny the community of the benefit of employment due to a manufacturer's unsuccessful efforts to pay the tax); Last, Smith saw the potential for public malcontent fostered by intrusive tax examiners, and injudicious tax schemes. ${ }^{491}$

Smith's concern about taxes follows naturally from his view of the division of labor, the free market, and voluntary exchange. The dominant theme of Smith's writings is the need for states to promote domestic production and industry of its citizens, avoiding both the temptation to impose high tariffs, and the temptation to rule the economy with an iron fist, rather than permit the work of the invisible hand.

\footnotetext{
${ }^{489} \mathrm{Id}$. at 446.

${ }^{490} \mathrm{Id}$. at 478 .

${ }^{491}$ Id. at $478-479$.
} 


\section{Milton Friedman on the Weapon of Choice, and Voluntary Exchange}

Drawing from the lengthy tradition of free-market economics outlined systematically by Adam Smith, economist and Nobel laureate Milton Friedman penned his modern classic Free to

Choose ${ }^{492}$ In the fashion of an economist, Friedman's work proceeds in an orderly manner as he builds the case that "economic freedom is an essential requisite for political freedom." ${ }^{493}$ The early part of Friedman's work emphasizes his philosophy of the power of free markets, and then advances an attendant argument against market controls before applying his model to policy issues in the U.S.

Friedman begins his work with an example of Smith's invisible hand, detailing the many voluntary exchanges necessary in the production of a simple lead pencil. ${ }^{494}$ Like Smith's pin maker, Friedman walks readers through the production of a pencil, beginning with the utilization of natural resources such as trees for the pencil's exterior, to the incorporation of graphite into the pencil's center, to the final step of affixing an eraser to the top. ${ }^{495}$ Unsurprisingly, Friedman's argues that Smith's analysis of voluntary exchange is a spot-on reflection of the global economy, and the price system. ${ }^{496}$

But Friedman extends the analysis to demonstrate how prices emerging from voluntary transactions benefit society in three key ways ${ }^{497}$ First, prices transmit only important information to players within the market who need to know. ${ }^{498}$ This allows for the efficient flow of information since information transmitters, and information seekers have an incentive to locate

\footnotetext{
${ }^{492}$ Milton Friedman \& Rose Friedman, Free to Choose: A Personal Statement (Harcourt 1990)

${ }^{493} I d$. at 2 .

${ }^{494}$ Id. at 11 .

${ }^{495}$ Id. at $11-13$.

${ }^{496}$ Id. at 13.

${ }^{497}$ Id. at $13-14$.

${ }^{498}$ Id. at 15.
} 
one another in order to arrive at an equitable price between buyers and sellers. ${ }^{499}$ Transmission typically occurs in organized markets, and communication systems targeting particular sectors. ${ }^{500}$

Second, prices provide meaningful incentives "to react to the information and the means to do so." ${ }^{501}$ In particular, buyers and sellers have an incentive to react to price increases, and/or decreases if they are to maximize their respective incomes. ${ }^{502}$ This incentive to act leads to greater efficiency within the market, as buyers and sellers, arrive at acceptable margins of production in meeting the demands for output, even as prices communicate the most efficient way to produce the product by supplying information about the cost of supplies and materials. ${ }^{503}$ Prices also provide meaningful incentives between employers and workers by communicating information through wages ${ }^{504}$ Higher wages tend to provide workers with an incentive to act in the labor market as they make choices about their place of employment. ${ }^{505}$

Third, as Friedman alludes to in his discussion of incentives, prices provide for the societal distribution of income..$^{506}$ Friedman argues that the market, through the price system, sets the price on the services provided by manufacturers and entrepreneurs alike - whether the service consists of the production of goods, the sale of productive resources, or the provision of productive services in the form of human capital. ${ }^{507}$ Not only this, but markets provide for the distribution of income much more efficiently than any form of centralized planning. ${ }^{508}$

Buried amid his discussion of prices, Friedman offers a critical insight into his view of free markets. He notes that chance fundamentally impacts the lot of individuals within the

\footnotetext{
${ }^{499} I d$.

${ }^{500} \mathrm{Id}$. at 16.

${ }^{501} I d$. at 18 .

${ }^{502} \mathrm{Id}$.

${ }^{503} \mathrm{Id}$.

${ }^{504} I d$. at 19.

${ }^{505} \mathrm{Id}$.

${ }^{506} \mathrm{Id}$. at 20.

${ }^{507} \mathrm{Id}$. at $20-21$.

${ }^{508} \mathrm{Id}$. at 22 .
} 
society. ${ }^{509}$ Chance takes the form of one's family, cultural environment, physical appearance, mental capacity, inheritance, and even health. ${ }^{510}$ Moreover, chance combined with the opportunity to choose creates a hodgepodge mix that has a tremendous effect on the price market for our services and resources. ${ }^{511}$ In effect, Friedman argues that choice is the key for building or dissipating what resources we have, however great or paltry they may be. ${ }^{512}$

The result of Friedman's price system is a network of voluntary cooperation, spurred on by mutually beneficial interactions within societies ${ }^{513}$ Friedman's major point is that the entire operation occurs without any form of decrees or coercion, without any planning, all based upon the self-interests of individuals. ${ }^{514}$ In turn, Friedman defends individual "self-interests" from those who would dismiss it as "myopic selfishness, as exclusive concern with immediate material rewards." ${ }^{515}$ Far from being a selfish enterprise, a person's self-interest is merely whatever the individual values, and whatever objective the individual seeks to pursue..$^{516}$ Friedman notes that the scientist, missionary, and philanthropist all seek to advance a particular self-interest whether it is pushing the boundaries of science, "converting infidels," or seeking to advance a cause for the greater good..$^{517}$

Regarding the role of government in Friedman's scheme, he quotes at length the perspective of government articulated by Adam Smith, namely the protection of individuals from coercion, the administration of justice, and the establishment of public institutions. ${ }^{518}$ While Friedman readily admits the validity of the first two, he warns against the dangers of government

\footnotetext{
${ }^{509} \mathrm{Id}$.

${ }^{510} \mathrm{Id}$.

${ }^{511} \mathrm{Id}$.

${ }^{512} \mathrm{Id}$.

${ }^{513} \mathrm{Id}$. at 26.

${ }^{514}$ Id. at $26-27$.

${ }^{515}$ Id. at 27.

${ }^{516} \mathrm{Id}$.

${ }^{517}$ Id.

${ }^{518}$ Id. at $29-30$.
} 
encroachment hidden in Smith's third duty of government. ${ }^{519}$ His concern is not so much about the ability of governments to establish public institutions as it is about the scope of their authority. Friedman argues that "the burden of proof" justifying the government action should be on its proponents, establishing a presumption against government action absent some compelling reason. ${ }^{520}$ One final duty of government that Friedman concocts independent of Smith is that government has an obligation "to protect members of the community who cannot be regarded as “responsible" individuals." ${ }^{21}$ This suggests a limitation of freedom in Friedman's model, placing the onus on society to draw the line between who is a responsible person and who is not. ${ }^{522}$ Friedman suggests that children and "madmen" be held to a different standard of responsibility, but does not suggest any categorical designations for individuals eligible for the paternalism of the state. ${ }^{523}$

Like a good scholar, having established his model for the market, and the role of government, Friedman then proceeds to attack his opponents. He launches his first assault against "the tyranny of controls," defined as "the maze of restraints and restrictions that makes almost all of us worse off than we would be if they were all eliminated." 524 The argument unfolds into a defense of free trade where Friedman suggests that consumers lose the most relative to the gains created by tariffs and trade restrictions. ${ }^{525}$ For Friedman, the true problem of trade tariffs is that they obfuscate the principle of comparative advantage whereby nations produce only those things that they are best at producing. ${ }^{526}$ Producing anything else, under this principle, results in inefficiency, leading to less efficient workers creating products that can be made more efficiently

\footnotetext{
${ }^{519} I d$. at $30-31$.

${ }^{520}$ Id. at $31-32$.

${ }^{521} I d$. at 32 .

${ }_{522} I$ d.

${ }^{523} \mathrm{Id}$. at 33.

${ }^{524} \mathrm{Id}$. at $38-39$.

${ }^{525} \mathrm{Id}$. at 39.

${ }^{526} \mathrm{Id}$. at 44.
} 
elsewhere. ${ }^{527}$ The result is that the actual productive capacity of the inefficiently producing workers remains suppressed as they create products that do not cater to their relative industrious strengths. ${ }^{528}$

Given his defense of free trade, and earlier defense of voluntary exchange in free markets, it is merely a logical extension that Friedman would attack central economic planning. ${ }^{529}$ For Friedman, central economic planning represents the great threat to free enterprise and free markets. ${ }^{530}$ Friedman argues that in nations where "any large element of individual freedom" is found, a corresponding measure of progress "at the disposal of ordinary citizens" is also found, along with economic activity organized by the free market. ${ }^{531}$ By contrast, according to Friedman's research, state controlled planning tends to result in lower standards of living, and scant individual power for citizens. ${ }^{532}$

Friedman's prescription for centralized planning is the maximization of economic and human freedom, or the freedom to choose. ${ }^{533}$ Regarding economic freedom, Friedman defines this as the "freedom to choose how to use our income: how much we spend on ourselves and on what items; how much to save and in what form; how much to give away and to whom." ${ }^{, 34}$ This choice, Friedman argues, is exercised through the political process "when you enter the voting booth," although the outcome of elections tends to produce conformity to a political agenda without unanimity, and no guarantee that one's individual preference will actually be accomplished. ${ }^{535}$

\footnotetext{
${ }^{527} \mathrm{Id}$. at 45.

${ }^{528} \mathrm{Id}$.

${ }^{529} \mathrm{Id}$. at 54.

${ }^{530} \mathrm{Id}$.

${ }^{531} \mathrm{Id}$. at $54-55$.

${ }^{532} \mathrm{Id}$. at 55.

${ }^{533} \mathrm{Id}$. at 65.

${ }_{534} \mathrm{Id}$.

${ }^{535} I d$. at $65-66$.
} 
Regarding human freedom, Friedman argues that restrictions on economic freedom typically result in the restriction of human freedoms such as the free speech, free press, and even the freedom of religion. ${ }^{536} \mathrm{He}$ notes that governmental agendas can have a "chilling effect" when uncooperative businesses face the threat of increased regulation should they oppose a particular point of view. ${ }^{537}$ Similarly, the press, which depends upon the government in a myriad of ways, can be subject to informational blacklisting, and pressure from politicians seeking to influence the tenor of publications. ${ }^{538}$ Finally, Friedman notes that religious orders such as the Amish have been routinely harassed by governmental regulations, and even prosecuted - both for refusing to pay taxes on religious grounds, and for refusing to comply with various regulations that violate the tenants of their faith..$^{539}$

While Friedman concedes that there is a need for some restrictions in an "interdependent society," he rejects the notion that society has reached an appropriate level of regulation, insisting that we have more regulations than necessary and that a reasonable goal should be the elimination of restrictions, rather than the creation of more ${ }^{540}$ His solutions for the burgeoning "welfare state" in the U.S. are similar. Friedman argues for a two-point reform of the welfare system, consisting of the replacement of the array of welfare programs with a single system premised upon a negative income tax, while restricting Social Security to current beneficiaries and phasing out future claimants. ${ }^{541}$ Friedman's negative income tax would set a baseline of deductions and low-income allowances such that the government would provide taxpayers a fixed subsidy based on their allowances. ${ }^{542}$ Assuming the taxpayer's income did not exceed their

\footnotetext{
${ }^{536} \mathrm{Id}$. at $67-69$.

${ }^{537} \mathrm{Id}$. at 68.

${ }^{538} I d$. at 69.

${ }^{539} \mathrm{Id}$.

${ }^{540} \mathrm{Id}$.

${ }^{541} \mathrm{Id}$. at 120.

${ }^{542}$ Id. at 121.
} 
allowances, they would continue to receive the subsidy. ${ }^{543}$ Once a taxpayer's income increased beyond the allowances, then the subsidy would be decreased proportionately. ${ }^{544}$

Even while his scheme for the welfare state is an ideal, like many of the libertarian scholars discussed, Friedman is realistic about the opportunity for its implementation. ${ }^{545}$ His alternative, accordingly, is the piecemeal implementation of a free market agenda that cuts wasteful spending, and eliminates needlessly paternalistic programs. ${ }^{546}$

\section{Thomas Sowell on the Importance of Property Rights for Law and Order}

Thomas Sowell, like the Cato Institute's David Boaz has written a number of works, both in the fields of economics and libertarian philosophy. Of particular relevance to this discussion is Sowell's lengthy tome, Basic Economics. ${ }^{547}$ Like Boaz's Libertarianism, Sowell's Basic Economics is basically a textbook, presenting complex economic concepts in an eminently comprehensible way. Sowell's text discusses a number of topics, ranging from the operation of prices and markets (which we have already discussed at length), to the role of industry and commerce in society, to labor markets, investments, macro-economic theory, trade, and a variety of special topics. ${ }^{548}$ Even though his text has relevance to a many of the topics discussed so far, his lengthy analysis of property rights is of particular importance in our analysis of the role of markets in a libertarian framework of rights.

Sowell begins his examination of property rights by underscoring their importance "to the economy as a whole," arguing that the significance of property rights in economics is the way in which they affect "the allocation of scarce resources, which have no alternative uses." ${ }^{449}$ Sowell's

\footnotetext{
${ }^{543} \mathrm{Id}$.

${ }^{544} I d$.

${ }^{545} I d$. at 126.

${ }^{546} \mathrm{Id}$.

${ }^{547}$ Thomas Sowell, Basic Economics, 422 (Basic Books 2010).

${ }^{548} I d$. at $\mathrm{v}-\mathrm{vi}$.

${ }^{549} \mathrm{Id}$. at 422.
} 
premise is that property rights are crucial not because of their particular affinity to individual property owners, but because of the way they can benefit the economy in the aggregate through their productive uses and alienability. ${ }^{550}$ Specifically, Sowell argues that "property rights create self-monitoring" mechanisms in the production of goods. ${ }^{551}$ Whether it is the farmer selling produce, or McDonald's and their concern with a sustainable supply of cattle, those goods that are owned tend to be goods that are well regulated by the parties with a vested interest in their continued use. ${ }^{552}$ Similarly, farmers with a property interest in the goods they sell tend to monitor their crops to guard against spoilage. ${ }^{553}$ There is no regulatory obligation placed upon the farmer, but that of the simple fact that the farmer will lose money should he sell spoiled produce. ${ }^{554}$ The result of a property rights system is the production of higher quality goods, without the need for a formal regulatory apparatus. ${ }^{555}$

Similarly, a property rights system tends to guard against Garrett Hardin's tragedy of the commons, or the overexploitation of resources to the detriment of all. ${ }^{556}$ Sowell reasons that property rights reduce the incentive to overexploit resources in that they provide an incentive for owners to use their land in such a way that it is sustainable. ${ }^{557}$ To wit, if owners wish to profit off of their resources, then they must ensure its sustainability. ${ }^{558}$ That many do, leads Sowell to conclude, "it is those things not owned by anybody" which are most polluted or overexploited. ${ }^{559}$ Naturally, Sowell's major point in his discussion of the tragedy of the commons is to situate the private property rights system as a potential mitigation of the tragedy of the commons itself.

\footnotetext{
${ }^{550} \mathrm{Id}$.

${ }^{551} I d$. at 423.

${ }^{552}$ Id. at 424 .

553 Id. at 423.

${ }^{554} \mathrm{Id}$.

${ }^{555} I d$.

${ }^{556} I d$. at 424.

${ }^{557} \mathrm{Id}$.

${ }^{558} \mathrm{Id}$.

${ }^{559} \mathrm{Id}$.
} 
When goods are owned in common, all owners have an incentive to maximize their exploitation vis-à-vis other owners. But if ownership is defined through a system of property rights, then those who own the rights have an incentive to see to their sustainability.

In light of his discussion of the self-monitoring, self-sustaining nature of property rights systems, Sowell's discussion can really be summed up with the word "incentives." Private property systems tend to provide incentives for property owners to earn a profit in a "profit-andloss economy," creating a corresponding incentive not to allow one's property to fall into a state of dereliction, or a state of overexploitation. ${ }^{560}$

\section{Hernando De Soto's Mystery of Capital}

If Thomas Sowell can be said to have outlined the boundaries of the property rights system, economist Hernando De Soto's The Mystery of Capital, underscores why such a system is crucially important for economic success. Hernando De Soto made his mark for his research on ways to reform property systems in the developing world. He is widely regarded among both the international development community and economists worldwide. De Soto's work has focused largely on the development of the "informal economy," the basic premise of which can be typified as a crusade against “dead capital.” In De Soto's view, dead capital exists when there is no system for converting physical assets into capital, such as the common practice of "using your house to borrow money to finance an enterprise." 561

Though the idea is deceptively simple, De Soto explains that the "relevant economic features of assets" are recorded only through "the records and titles that formal property systems provide. ${ }^{" 562}$ In other words, absent a formal property system, there is no mechanism for

\footnotetext{
${ }^{560} I d$. at 426.

${ }^{561}$ Hernando De Soto, The Mystery of Capital: Why Capitalism Triumphs in the West and Fails Everywhere Else, 40 (Basic Books 2000).

${ }^{562} \mathrm{Id}$. at 46.
} 
implementing Adam Smith's price system, let alone the communicative benefits of prices outlined by Milton Friedman. Stating matters simply, De Soto argues, "the formal property system...is the place where capital is born." ${ }^{, 63}$ Though De Soto's process is not particularly glamorous, merely advocating that governments implement processes for the description, organization, recording, and preservation of the "economically and socially useful aspects about assets" in a title, it is exactly this process that communicates what is "economically meaningful about any asset" in the price system. ${ }^{564}$ The process of formal property is what actually transmits information, communicating "the potential value of an asset," allowing owners to control and ultimately profit from it. ${ }^{565}$

After establishing the importance of formal property systems to the western system of capitalization, De Soto explores six ways in which formal property systems allow citizens to create capital. ${ }^{566}$ First, De Soto argues that property systems set the economic potential of an asset. ${ }^{567}$ This means that the "potential value" of an asset can be revealed in its title where potential value is first described and registered. ${ }^{568}$ Such information communicates the "representation of economic concepts about" the property, allowing for an understanding about the potential for the property's ability to produce value. ${ }^{569}$

Second, formal property systems allow for the integration of dispersed information into one system of property rights. ${ }^{570}$ Even while local rules from a multitude of localities once governed property transactions, integrated property systems have enabled citizens to "obtain descriptions of economic and social qualities of any available asset without having to see the

\footnotetext{
${ }^{563}$ Id. at 47.

${ }^{564} \mathrm{Id}$. at $46-47$.

${ }^{565} \mathrm{Id}$. at 47.

${ }^{566}$ Id. at 49.

${ }^{567} \mathrm{Id}$.

${ }^{568} \mathrm{Id}$. at 50.

${ }^{569} \mathrm{Id}$.

${ }^{570} \mathrm{Id}$. at 52.
} 
asset itself." This facilitates smoother transactions, and allows potential buyers to understand "what opportunities create surplus value," while allowing them to evaluate the transaction. ${ }^{571}$

Third, De Soto argues that formal property systems make people more accountable in their business dealings. ${ }^{572}$ Rather than hiding behind veils of informality, property owners forfeit anonymity, meaning that non-payment for goods or services triggers a number of repercussions including interest penalties, fines, and credit downgrades ${ }^{573}$ While this "respect" for transactions is hardly a western phenomenon, according to De Soto it is, nevertheless, the product of "having enforceable formal property systems. ${ }^{\$ 774}$ In communities without formal property systems, no such safeguards of accountability exist, leaving transactions to the tastes of "the grubby basement of the precapitalist [sic] world." 575

Fourth, De Soto describes how formal property systems make "assets fungible." ${ }^{576} \mathrm{On}$ this score, De Soto merely notes that property systems allow for individuals to discriminate between disparate assets by making easy comparisons. ${ }^{577}$ This allows for assets to be divvied up among a number of owners through a system of shares, allowing shareholders to invest or divest depending upon their assessment of physical assets. ${ }^{578}$ Such a method allows for the alienability of lands or assets by enabling interested parties to buy out the shares of willing sellers, rather than allowing shares to idly subdivide until they are of little value to anyone. ${ }^{579} \mathrm{~A}$ fifth and related way that property systems create capital is that they transform owners "into a network of

\footnotetext{
${ }^{571} I d$. at 54.

${ }^{572} \mathrm{Id}$.

${ }^{573} \mathrm{Id}$. at 55.

${ }^{574} \mathrm{Id}$.

${ }^{575} \mathrm{Id}$. at 56.

${ }^{576} \mathrm{Id}$.

${ }^{577} \mathrm{Id}$. at $56-57$.

${ }^{578} \mathrm{Id}$. at 57.

${ }^{579} \mathrm{Id}$.
} 
individually identifiable and accountable business agents. ${ }^{" 580}$ According to De Soto, formal property's unique "contribution to mankind is...that it radically improved the flow of communication about assets and their potential," thereby elevating the status of property owners to that of economic agents with assets in a broader network. ${ }^{581}$ This change in communications allows for financial institutions to better assess credit worthiness, making "risk more manageable," and allows lenders to make decisions about securities much more quickly, further providing for the assembly of "assets into more valuable combinations."

Finally, De Soto argues that formal property systems create capital by "protecting transactions" via "public, record-keeping systems." ${ }^{583}$ These systems provide information about any restriction that may limit an asset's "realization," including easements, leases, bankruptcies, and mortgages. ${ }^{584}$ Similarly, record systems also allow for private entities to assist in the security of a transaction by providing a number of financial and recording services that would ordinarily be beyond the knowledge of individual buyers and sellers. ${ }^{585}$ These checks of the property system allow for assets to lead dual lives "as capital," providing for the movement of "large amounts of assets with very few transactions." 586

\section{Ayn Rand on the Importance of Freedom and Creative Capacity}

Finally, no discussion of the role of markets in preserving freedom would be complete without a discussion of the works of philosopher Ayn Rand, and her rigorous defense of individual liberty, free markets, and human creative capacity in Atlas Shrugged ${ }^{587}$ A Russian immigrant, Rand's philosophy was heavily influenced by her life experience growing up during

\footnotetext{
${ }^{580} \mathrm{Id}$. at 58.

581 Id. at 59.

${ }^{582} \mathrm{Id}$. at $60-61$.

${ }^{583}$ Id. at 61 .

${ }^{584} \mathrm{Id}$.

${ }^{585} \mathrm{Id}$.

${ }^{586} \mathrm{Id}$. at 62.

${ }^{587}$ Ayn Rand, Atlas Shrugged (Signet 1957).
} 
the Bolshevik Revolution, where she viewed the United States as the model of the ideal, free nation. ${ }^{588}$ The theme of Rand's work is the "the role of the mind in man's existence - and, as corollary, the demonstration of a new moral philosophy: the morality of rational self-interest." $\$ 89$ While some libertarians have parted company with Rand's views of metaphysics, ethics, and religion, her political and economic philosophy was essentially libertarian, and her novels demonstrate the profound power of individual choice within society and markets. ${ }^{590}$

There are surely a number of more capable book reviews of Atlas Shrugged than the one that follows. But this analysis is not so much to critique Ms. Rand's literary talents, as it is to distill the basic ideas of her philosophy, Objectivism. The sum of Rand's beliefs is ably summarized within one chapter of her massive work, in a speech delivered by latent, main character John Galt. ${ }^{591}$ To this point in Rand's novel, political and business leaders around the world have colluded to nationalize a number of major industries ${ }^{592}$ Galt has encouraged the world's great innovators and creators of wealth to withdraw from society, taking their talents and capital with them. ${ }^{593}$ The result has been the utter breakdown of society, with government and government-subsidized businesses left powerless to replace the innovation of the world's great entrepreneurs. ${ }^{594}$ After convincing the world's "movers" to go on strike, Galt delivers an address to the United States, which Rand frames as a reaction against dependency in the social welfare state - a strike against "the creed of unearned rewards and unrewarded duties... a strike against the dogma that the pursuit of one's happiness is evil. We are on strike against the doctrine that

\footnotetext{
${ }^{588} \mathrm{Id}$. at 1072 .

${ }^{589} \mathrm{Id}$. at 1076

${ }^{590}$ Boaz, supra n.338 at 55.

${ }^{591}$ Rand, supra n.587 at 923.

${ }^{592}$ Id . at 793.

${ }^{593}$ Id . at 925.

${ }^{594}$ Id. at 924.
} 
life is guilt." 595 These early strains of Galt's speech underscore Rand's frustration with governmental systems that esteem the authority of the state about the dignity of individuals. In Rand's view, the true immorality of the system Galt faced was precisely that it provided services to individuals through the process of economic nationalization, and at the expense of the creative faculties of free people.

Rand's solution to the quagmire besetting the social welfare state was the maximization of human reason. Galt remarks:

The most depraved sentence you can now utter is to ask: Whose reason? The answer is: Yours. No matter how vast your knowledge or how modest, it is your mind that has to acquire it. It is only with your own knowledge that you can deal. It is only your own knowledge that you can claim to posses or ask others to consider. ${ }^{596}$

This summary is the heart of Rand's message. Under her ethical framework, all virtues - whether morality, rationality, independence, integrity, honesty, or justice - depend upon the acceptance of an individual's decision to choose to be productive. ${ }^{597}$ Such a choice to Rand is synonymous with choosing to live, giving humanity "consciousness" to control its existence, and a process for acquiring knowledge that can be used to "remake" the world into "the image of one's values." This opportunity is not a limited one in Rand's view. She writes eloquently that "your work is yours to choose, and the choice is as wide as your mind, that nothing more is possible to you, and nothing less is human." 599

The preceding section epitomizes the theme of Rand's entire novel, and the values present in a number of her other works. For Rand, the ultima ratio of human existence is the

\footnotetext{
${ }^{595} \mathrm{Id}$. at 925 .

${ }^{596} \mathrm{Id}$. at 930.

${ }^{597}$ Id. at $932-933$.

${ }^{598}$ Id. at 933.

${ }^{599}$ Id.
} 
ability of human beings to think creatively, to choose to work, and the opportunity maximize one's potential - the individual supporting one's own life, by one's own efforts. ${ }^{600}$

Regarding the role of the market, Rand argues that the archetypical relationship of existence is that of the trader. ${ }^{601}$ Rand defines a trader as one "who earns what he gets and does not give or take the underserved. A trader does not ask to be paid for his failures, nor does he ask to be loved for his flaws." ${ }^{602}$ Under Rand's view, markets essentially facilitate human relationships. That they should be kept as free as possible is evident when Rand argues for a simple service/payment model of markets, one void of subsidies, and one in which all individuals have the right to compete on the virtues of their own merit, free of coercion. ${ }^{603}$ This principle is summed up in the last line of Galt's 50-plus page speech: "I swear - by my life and my love of it - that I will never live for the sake of another man, nor ask another man to live for mine."

Rand's great contribution to the role of markets in securing freedom, as gleaned from both her novel and her philosophy, is the notion that human creative capacity is the lynchpin of market interactions. In Atlas Shrugged Galt's strike was ultimately successful because the world needed the creative faculties of individuals regardless of their motivation, whatever their selfinterest. Under Rand's philosophy, self-interested profit is not a vice but a virtue - a laudable attribute, one that reflects the human striving to expand the reaches of knowledge, through the deployment of creative abilities in a productive exchange with other individuals. For Rand, free markets simply mean that individuals have the capacity to fulfill their creative potential through productive work.

\footnotetext{
${ }^{600} I d$. at 935.

${ }^{601} \mathrm{Id}$.

${ }^{602} \mathrm{Id}$.

${ }^{603} \mathrm{Id}$. at $936-937$.

${ }^{604} \mathrm{Id}$. at 979.
} 


\section{CHAPTER 4}

\section{CRITIQUES OF LIBERTARIANISM}

Having discussed the major elements of libertarian philosophical thought, it is necessary to explore the philosophical criticisms of libertarianism in order to distill the components of libertarianism that are most applicable to Indian Country and the stated goal of measured tribal separatism. What follows is a discussion of the major arguments levied against libertarian thought drawing from the tradition of communitarian philosophy. While there are a number of philosophical theories that could be used to critique libertarianism, in general, communitarian principles tend to reside at the opposite end of the philosophical spectrum from the libertarian tradition, emphasizing the role of government in establishing social justice; to support the strengthening of communal/local institutions; and to distrust the free-market system particularly corporations - for want of greater oversight of negative market externalities. In many ways, the communitarian view of government is the view from which many Indian law scholars approach the question of Indians rights as influenced by tribal communal traditions, so it is important to explore critiques of libertarianism from this perspective.

\section{A. What's the Role of Government in Society?}

At the core of many arguments between libertarians and communitarians is a fundamental disagreement over the role of government in society. Given the libertarian penchant for a 
minimal state apparatus, it is almost by definition that any view to the contrary would harbor designs for a larger role of government. Naturally, there are many such strains of political thought ranging from the various stripes of liberalism to authoritarianism and everything in between. Rather than addressing each view, the somewhat amorphous philosophy of communitarianism also provides a useful starting point for understanding some of the key disagreements about the role of government among competing political philosophies.

According to the Stanford Encyclopedia of Philosophy, communitarianism arose in reaction to John Rawls's $A$ Theory of Justice ${ }^{605}$ where he argued that society should be structured along two basic principles: 1) that each person has an equal right to the same basic liberties as everyone else; 2) that socio-economic inequalities should be arranged as to benefit the least advantaged and to open all positions within the society - including both private and public sector jobs - as to create conditions of fair, equality of opportunity. ${ }^{606}$ In response, a number of political philosophers began to make "certain core arguments" related to the normative importance of culture, the social nature of human beings, and the normative importance of community ${ }^{607}$ Regarding the importance of culture, communitarian philosophers ${ }^{608}$ argued that "cultural particularity should both make one sensitive to the possibility of justifiable areas of difference" between Western Culture, and the many non-Western cultures in the world. ${ }^{609}$ In turn, communitarian scholars argued that Rawls's philosophy presented "an overly individualistic conception of the self." ${ }^{\prime 10}$ Of particular importance in their critique was the fact that individuals can be significantly, inexorably impacted by their "various communal attachments," such as

\footnotetext{
${ }^{605}$ Daniel Bell, Edward N. Zalta, ed., The Stanford Encyclopedia of Philosophy, "Communitarianism," (Spring 2012), http://plato.stanford.edu/archives/spr2012/entries/communitarianism/.

${ }^{606}$ John Rawls, A Theory of Justice, 302 (Harvard U. Press 1971).

${ }^{607}$ Bell \& Zalta, supra n.605.

${ }^{608}$ Most communitarians avowedly shun the label. See Bell and Zalta n.605.

${ }^{609}$ Bell, supra n.605.

${ }^{610} \mathrm{Id}$.
} 
one's family, one's faith, and for our purposes one's tribe. ${ }^{611}$ Communitarians argued that the role of the state should not be confined to securing the power of individual freedom alone, but should instead be extended to promote these "social attachments" that are so instrumental to an individual's sense of self. ${ }^{612}$ Lastly, communitarians have argued for a greater state focus on political issues of concern to local citizens so that national governments may begin "emphasizing social responsibility and promoting policies meant to stem the erosion of communal life" at the local level. ${ }^{613}$

Interestingly, communitarianism in the U.S. tends to cut across the traditional left, right political divide. ${ }^{614}$ Communitarians often blame the left for its failure to sufficiently support the modern welfare state and for its emphasis of national solutions to issues of social justice, as opposed to empowering local communities to address the concerns most familiar to them ${ }^{615}$ By contrast, communitarians tend to blame the political right (including some libertarians) for promoting an agenda of "unregulated free-market capitalism" that tends to undermine social structures, and aid the process of globalization - the result of which is said to "pressures states into conforming to the dictates of the international marketplace." ${ }^{\prime 616}$ Communitarians suggest that these social ills can be rectified by shifting the normative predilections of individuals away from a "focus on personal fulfillment" toward a view of community fulfillment that focuses on the need to strengthen social institutions. ${ }^{617}$

Some scholars, such as the University of Arizona's Robert A. Hershey argue that a libertarian emphasis of the free market tends to result in a "myopic" subjugation of national

${ }^{611} I d$.
${ }^{612} I d$.
${ }^{613} I d$.
${ }^{614} I d$.
${ }^{615} I d$.
${ }^{616} I d$.
${ }^{617} I d$. 
sovereignty to the whims of multinational corporations ${ }^{618}$ Hershey notes that free trade agreements such as NAFTA "profoundly limit the policy choices of those countries where the factories are built," while also subordinating local concerns ${ }^{619}$ to the trade aspirations of multinational corporations. ${ }^{620}$ In many ways, Prof. Hershey’s skepticism of free markets, globalization, and multinational corporations echo many of the concerns raised by communitarians in their advocacy on behalf of local, community-based institutions and their arguments that the state should promote local interests such as cultural preservation, social justice, and developmental sustainability. Hershey's solution is to remake the institutions of "capitalism, corporationism, or globalization," so that they are more sustainable through the emerging technologies associated with "biomimicry." ${ }^{\prime 21}$ His remedy would see corporations and individuals alike begin to adopt processes for production and consumption that mimic the processes of production and consumption in nature. ${ }^{622}$ Given that such practices have not already been widely adopted, it stands to reason that a concomitant set of governmental regulations and incentives would be necessary to spark William McDonough's "a new industrial revolution” based upon biomimicry production processes ${ }^{623}$ By contrast, Hershey argues that such regulations are systems of "design failure," and indicate the need to do away with corporate subsidies. ${ }^{624}$

Some communitarians argue that the social problems identified by Prof. Hershey and others actually stem from the state's chronic inability to enforce its own laws, and preserve social

\footnotetext{
${ }^{618}$ Robert A. Hershey, Globalization and the Transformation of Cultures and Humanity, "Creating the Corporate Utopia: Transnationalism, the W.T.O. and the I.M.F.",

http://www.ecoliteratelaw.com/10_CorporateUtopia.cfm?sect=text.

${ }_{619}$ Hershey takes particular issue with water consumption, and subsidies to industries, including agribusinesses.

${ }^{620}$ Hershey, supra n.618.

${ }^{621} \mathrm{Id}$.

${ }^{622}$ Id.

${ }^{623}$ Id.

${ }^{624}$ Id.
} 
institutions and local interests. ${ }^{625}$ In a piece critical of Hernando De Soto - whose work is discussed at length above - columnist Madeline Bunting argues that De Soto's theory of capital fails because it assumes there are power structures in developing economies to effectively formalize underground markets - when in fact there are none ${ }^{626}$ Bunting dryly notes that in some developing countries, the "local mafia has far more clout than any government." ${ }^{27}$ Ms. Bunting's obvious point is that the governments need to be strengthened before they can begin implementing De Soto's ideas of capital effectively. Rather than focus on property rights alone, Bunting would create governmental institutions to check "western multinational" interests and fight crime even before De Soto's regime of property rights is implemented. ${ }^{628}$

\section{B. Individual Liberty v. Community}

Aside from differences over the role of government in society, libertarians and communitarians tend to differ in their respective views of individual rights, and communal rights. Author Nick Rosen captures this sentiment superbly in his book Off The Grid. ${ }^{629}$ There, Rosen explores the motley of individuals attempting to make a go of life in the United States by living in communities "off the grid...free of the Man," and beyond attachment to local municipalities and their consumer-driven societies. ${ }^{630}$ Rosen's interviews lead him to conclude that Americans no longer "trust in the government to protect its citizens" due to the collapse of a corrupt financial system, concerns about America's food-distribution system, and the breakdown of American communities - particularly those in the Rust Belt. ${ }^{631}$ Rosen suggests that the trend

\footnotetext{
${ }^{625}$ Madeline Bunting, Manchester Guardian, "Economist Hernando de Soto: Fine Words, Flawed Ideas," http://www.commondreams.org/views/091100-103.htm.

${ }^{626} I d$.

${ }^{627} \mathrm{Id}$.

${ }^{628} I d$.

${ }^{629}$ Nick Rosen, Off the Grid: Inside the Movement for More Space, Less Government, and True Independence in Modern America (Penguin 2010).

${ }^{630}$ Id. at 1.

${ }^{631} \mathrm{Id}$. at 289.
} 
against consumerism may be "irreversible," due to the mid-2009 recession and the limping global economy that has taken its place. ${ }^{632}$ As Rosen's analysis suggests, one clear difference between libertarianism and communitarians is the prioritization of the collective over the individual. Rosen's stories of "off-gridders" frequently mention a ferocious commitment to living in a community among like-minded individuals that is apart from the influences of modern American consumerism. ${ }^{63}$ In many of these communities, individuals undertake a voluntary, "cheap, and eco-conscious living" in effort to bolster the long-term prospects of maintaining community with "post-consumer consumers." ${ }^{934}$ The problem for such individuals with the economic and political system is not so much a lack of choice as it is a lack of opportunity to live in community with like-minded individuals in a manner consistent with their shared standards of ethics and conservational integrity.

Similarly, Harvard Professor, and two-time Pulitzer Prize-winning author Edward O. Wilson writes at length about the need for a more communal approach to life among the inhabitants of planet Earth in his now classic work The Future of Life ${ }^{635}$ Having explained in depth the ecological and sociological problems besetting the planet, Wilson frames the issue "like all great decisions" as a moral one, appealing to humanity to preserve the "natural world." ${ }^{636}$ Wilson writes:

A sense of genetic unity, kinship, and deep history are among the values that bond us to the living environment. They are the survival mechanisms for ourselves and our species. To conserve biological diversity is an investment in immortality. ${ }^{637}$

\footnotetext{
${ }^{632} I d$. at $171-177$.

${ }^{633} \mathrm{Id}$. at 181 .

${ }^{634}$ Id. at 192

${ }^{635}$ Edward O. Wilson, The Future of Life (Vintage 2002).

${ }^{636} \mathrm{Id}$. at 130 .

${ }^{637} \mathrm{Id}$. at 133.
} 
Wilson's point as it relates to the individual/communal dichotomy is that individuals from all ranks are inspired by nature, dumbfounded by its mysteries, and eager to draw from its many unknowns through a "predisposition to explore." ${ }^{638}$ In other words, the whole of humanity has a vested, shared, communal interest in preserving (as opposed to ravenously consuming) what remains of our natural world. For Wilson, the solution is for the Earth's denizens reorient their collective, ethical views in such a way that individuals reject "political ideology and religious dogma," and seek to "disarm" stereotypes of opposing ideologies so that every effort can be made to search for "common ground" in saving the environment and planet - what Wilson calls a new, "united environmental movement."

Finally, perhaps the most powerful argument against a libertarian focus on individual rights comes from economists Ted Halstead and Clifford Cobb who argue for a more holistic measure of "national well-being" that will replace the oft-cited measure of a nation's Gross Domestic Product. ${ }^{640}$ Fundamentally, Halstead and Cobb challenge the GDP for making an accounting of "well-being" based upon the services and goods a country produces. ${ }^{641}$ Of special importance to Halstead and Cobb is the failure of the GDP metric to account for the depletion of natural resources that result from productive capacity, and its failure to account for social externalities - such as pollution, divorce, disease, and informal exchanges within an economy, such as parenting and childcare. ${ }^{642}$

Their solution is to adopt a progress metric, dubbed the Genuine Progress Indicator, that "more accurately" reflects a nation's collective well-being than the GDP." ${ }^{643}$ The new model is

\footnotetext{
${ }^{638} \mathrm{Id}$. at $146-148$.

${ }^{639}$ Id. at $152-155$.

${ }^{640}$ Ted Halstead \& Clifford Cobb, The Case Against the Global Economy and for a Turn to the Local, "The Need for New Measurements of Progress" (Sierra Club 1996).

${ }^{641} \mathrm{Id}$. at 198.

${ }^{642} I d$. , at $200-202$.

${ }^{643} \mathrm{Id}$. at 202.
} 
said to represent a more communal approach to a nation's progress in that it accounts for "some twenty aspects of economic life" that the GDP either ignores or perversely accounts for. ${ }^{644}$ Among a bevy of factors, the GPI considers natural resource depletion, pollution, environmental damage, non-market transactions such as homemaking, leisure time, employment rates, economic equality, and sustainable investing to name a few ${ }^{645}$ Citing the example of the developing world, Halstead and Cobb argue that the informal economy of much of the southern hemisphere is one in which women perform a number of crucial social functions, yet never have their work accounted for on the national ledgers. ${ }^{646}$ In their view, a libertarian emphasis on individuals rights, and an economic view based upon a nation's productive capacity is simply insufficient to represent the overall well being of a society. Halstead and Cobb argue repeatedly that more complex systems of measure are necessary in order to accurately reflect the state of things within the state. Though not entirely incongruent with libertarianism, Halstead and Cobb's approach to well-being measurement is certainly more communal in that its metric includes a number of social measures that are not considered under the GDP. ${ }^{647}$

\section{Economic Critiques}

In addition to disagreements about the role of government in society, and a libertarian emphasis of individual rights, critics of libertarianism also take issue with the primacy it places on capitalism, the freer operation of markets, and the normative externalities resulting from the entire free enterprise system. One example relating directly to Indian Country is Prof. Eric Kades' much discussed article titled The Dark Side of Efficiency, which details the history of the

\footnotetext{
${ }^{644} I d$. at $202-203$.

${ }^{645} \mathrm{Id}$.

${ }^{646} \mathrm{Id}$. at 205.

${ }^{647}$ See Hershey, supra n.618 at "Redefining Progress," http://www.ecoliteratelaw.com/03_RedefiningProgress.cfm?sect=text\&, identifying various well-being measurement alternatives to the GDP.
} 
Indian land expropriation measures undertaken by the U.S. Government. There, Kades explains some of the more pernicious effects of market efficiency, arguing that the Government's expropriation of Indian lands was a morally relativistic decision based upon the self-interest of the Nation, without regard to normative considerations of the Indians ${ }^{648}$ Far from "facilitating freed trade...European settlers adopted rules that maximized their own utility, regardless of Indian welfare. ${ }^{\prime 649}$ As Kades explains later, Indian land expropriation and its attendant governmental policies amounted to nothing more than a cold, dispassionate effort at "cost minimization." ${ }^{650}$

While Kades may not be an obvious ally (and to be clear, Kades avoids any discussion of the normative implications of his theory), his dissection of early-American, land expropriation policies makes a compelling case that markets can and do fail to consider social externalities such as those explored in the preceding section. Quite in contrast to a libertarian idealization of markets, the market place Eric Kades describes is a sterile one, based purely on the calculation of self-interest. It offers no room for ethical or normative considerations, and does not seem overly interested in the social costs that result from the destruction of cultures, loss of natural resources, and the effects of widespread displacement of Indian tribal nations. In one striking example, Kades frames the post-contact decimation of Indian populations from disease as a simple alteration of the terms of trade between Europeans and the Indians - one giving negotiation leverage to Europeans since tribal populations were crippled by epidemics and death. ${ }^{651}$ Given this interpretation of history, as Kades notes, efficiency would seem to have a dark side, indeed.

\footnotetext{
${ }^{648}$ Eric Kades, The Dark Side of Efficiency: Johnson v. McIntosh and the Exproriation of American Indian Lands, 148 U. Pa. L. Rev. 1065, 1109 (2000).

${ }^{649}$ Id. at 1108.

${ }^{650} \mathrm{Id}$. at 1185 .

${ }^{651} I d$. at $1141-1142$.
} 
Former Harvard Business School Professor David C. Korten makes similar observations in his critique of capitalism titled The Mythic Victor of Market Capitalism. Far from promoting free trade and increased globalization, Korten argues that Adam Smith was betrayed by his freemarket progeny, suggesting that Smith's “ideal market was a market that comprised solely small buyers and sellers, each too small to influence the market price of the commodities exchanged"as opposed to the multinational corporations that dominate the global market today ${ }^{652}$ Naturally, Korten takes issue with libertarian calls for market deregulation, arguing that such a move would further widen "the gap between the market's winners and losers, rich and poor." ${ }^{" 653}$ Rather than maintain a market that is "unencumbered by government restraint," or choose a market economy modeled after the "Soviet-style," Korten calls for a middle ground in the debate ${ }^{654} \mathrm{He}$ dismisses the current posturing by economists and scholars as a battle being fought by "ideological extremists" that need not be so stark..$^{655}$

Korten's solution to the morass is a new model for economic governances dubbed democratic pluralism. ${ }^{656}$ Under this scheme, Korten envisions "a dynamic tension among the forces of the market, government, and civil society to balance the often competing needs for essential order, the efficient production of goods and services, the accountability of power, the protection of human freedom, and continuing institutional innovation. ${ }^{957}$ Under this framework, markets would be "regulated" as opposed to "free," favoring domestic enterprises over foreign competition. ${ }^{658}$ In a nod to extant economic realities, Korten's avers that foreign competition would not be excluded under his model, rather it "simply does not share the preferred status" of

\footnotetext{
${ }^{652}$ David C. Korten, The Case Against the Global Economy and for a Turn to the Local, "The Mythic Victor of Market Capitalism" 183, 186 (Sierra Club 1996).

${ }^{653} \mathrm{Id}$. at 188 .

${ }^{654}$ Id. at $188-189$

${ }^{655} \mathrm{Id}$.

${ }^{656} \mathrm{Id}$.

${ }^{657} I d$. at 191.

${ }^{658} \mathrm{Id}$.
} 
local businesses. ${ }^{659}$ The difference between Korten's view of markets and the libertarian view of markets is almost self-evident. Korten's model for the economy envisions a much greater role for government to play in the operation of markets, while a libertarian vision of market freedom would find such a view as Korten's incompatible with its basic philosophical tenants.

Finally, as alluded to by Korten, arguments against libertarian views of markets are less often framed in terms of economics, and much more frequently posited as paramount issues of morality. One clear example of this critique is found in columnist and activist David Morris's essay titled Free Trade: The Great Destroyer. In line one of his piece, Morris poignantly argues, "free trade is the religion of our age," one drive by the belief that "the highest good is to shop." ${ }^{660}$ Of chief concern to Morris is the fact that "globalism" reorients individual priorities away from personal relationships and "neighborly ties" to a view that all human beings are merely "assets." ${ }^{\prime 61}$ Regarding perceived benefits of free trade, Morris argues that inequality has increased, and disparities have been exacerbated following the heels of two centuries of trade, although he offers little proof for his assertion. ${ }^{662}$

Given his vocal opposition to free trade regimes, Morris's alternative to free trade is to question its basic assumptions, beginning with efficiency, which he suggests measuring in terms of natural resources used in the production of goods ${ }^{663}$ Morris also takes issue with the price system, claiming that prices fail to send adequate signals because they ignore the costs of production placed on "society as a whole" (e.g., negative externalities) in the process of the producing goods ${ }^{664}$ Morris suggests that market prices should be adjusted to include the social

\footnotetext{
${ }^{659} I d$.

${ }^{660}$ David Morris, The Case Against the Global Economy and for a Turn to the Local, "Free Trade: The Great Destroyer" 218 (Sierra Club 1996).

${ }^{661}$ Id. at 221 .

${ }^{662} \mathrm{Id}$. at 223 .

${ }^{663} I d$. at 224.

${ }^{664} \mathrm{Id}$. at 225.
} 
$\operatorname{costs}^{665}$ of production so that prices will better align "with... [the goods] actual cost to society." 666 Along similar lines, Morris proposes rethinking the definition of the economic term externality. Assuming that society ultimately bears the cost of producing any goods, Morris questions the premise of what constitutes an externality in light of such interconnectedness. ${ }^{667}$ Unsurprisingly, Morris's ultimate solution to the conundrum of free trade is to step back from the global economy and focus on developing local economies in hopes that technology will one day enable us to produce goods locally, and more efficiently than the free enterprise system does today. ${ }^{668}$

Morris's obvious skepticism of free trade, and free markets illustrates many of the critiques levied against libertarianism's support of the same. Morris never advocates a return to a command/control economic model. But his anti-free trade policies represent a stark contrast with libertarianism's support for global markets, and comparative advantage methods of production. Suffice it to say, the two views are dramatically different.

\footnotetext{
${ }^{665}$ Such as the destruction of homes, the pain of broken lives, the costs of pollution, and noise pollution, etc. ${ }^{666} \mathrm{Id}$.

${ }^{667} \mathrm{Id}$. at 226.

${ }^{668} I d$. at $227-228$.
} 


\section{CHAPTER 5}

\section{A LIBERTARIAN FRAMEWORK FOR INDIAN RIGHTS}

\section{A Brief Response to the Communitarian Critiques}

While the communitarian critiques above raise interesting counter-points to various elements of libertarian philosophy, the arguments are ultimately unpersuasive because they misunderstand the basic tenant of libertarianism outlined by Robert Nozick at the beginning of our exploration: Libertarianism is fundamentally incremental. ${ }^{669}$ The purpose of crafting a libertarian framework for Indian rights is not to upend an obviously imperfect system, but to develop a new model for thinking about Indian rights based upon libertarian principles that can be implemented through policy changes over time.

With this caveat in mind, libertarian arguments for reducing the role of government in society should be understood in a similar manner. While scholars' and philosophers' views of the role and size of government are fairly said to reflect an ideological disposition, or world view, it is worth noting that the libertarian perspective advocating a limited government is not nearly so radical as communitarians suggest. The libertarian goal of reducing the size of government is not one of foisting broad change in governmental institutions upon the unwitting masses - à la some sort of libertarian revolution. The goal of reducing the role of government is much more modest. The libertarian vision for reducing the size of government is eminently tied to a vision of pragmatic change through continually identifying policy positions that are better handled by

\footnotetext{
${ }^{669}$ Nozick, supra n. 347 at 302.
} 
individuals and markets and suggesting steps toward what Milton Friedman called "incremental reform." $" 670$

Regarding communitarian views of government and the need to consider the social and communal attachments of peoples (as opposed to individuals), ${ }^{671}$ again, libertarian philosophy is not nearly so antithetical to the normative importance of culture and community as communitarians suggest. Nozick's "utopia" is actually a utopia of utopias whereby individuals make choices to freely associate how they would - governing, organizing themselves with other individuals who share similar values and interests. ${ }^{672}$ In plain language, Nozick argues, "there is no reason to think that there is one community which will serve as ideal for all people and much reason to think that there is not." ${ }^{, 673}$ Framing matters differently, one could argue that the libertarian philosophy of community and cultures is that they retain normative importance of themselves. The key difference, however, is that libertarians believe that social associations should be freely entered and freely maintained, rather than compulsory - more like a mini-utopia rather than a gulag. ${ }^{674}$

Regarding arguments for increased localism, critics arguing for a return to the local production of goods, ignore the reality of a our now global economy and the fact that buyers and sellers alike want goods and services that are simply not constrained by a geographic area ${ }^{675}$ The production of goods is an exercise of choice, and the global market allows ample room for transactions to be carried out across international borders. While some negative externalities associated with trade are, perhaps, inevitable (outsourcing, and pollution are especially

\footnotetext{
${ }^{670}$ Friedman, supra n.492 at 126.

${ }^{671}$ Daniel Bell, Edward N. Zalta, ed., The Stanford Encyclopedia of Philosophy, "Communitarianism," (Spring 2012), http://plato.stanford.edu/archives/spr2012/entries/communitarianism/.

${ }^{672}$ Nozick, supra n.347 at 309.

${ }^{673} \mathrm{Id}$. at 310.

${ }^{674} \mathrm{Id}$.

${ }^{675}$ Hershey, supra n.618.
} 
pernicious evils according to advocates of localism), libertarian philosophy finds some common ground with communitarians supporting the elimination of subsidies in hopes of creating a true market of free exchange, without world governments propping up their favored businesses and industries. $^{676}$

Finally, like differences over the role of governments in society, communitarian and libertarian perspectives of the role of markets harken back to elemental disagreements about the normative role of markets in general. But as the example raised by Prof. Kades demonstrates, the complicity of governmental action in creating the initial monopoly over Indian land transactions cannot be overlooked. The market failed as Kades notes, because the U.S. Government expropriated lands, rather than honoring the conventions of property rights elucidated by Locke, Smith, and even Rand - principles that make markets succeed ${ }^{677}$ To put matters a bit starkly, the Federal Government made the choice to expropriate Indian Lands because it had made an antecedent decision to ignore rights to Indian title. ${ }^{678}$

In sum, the framework for Indian rights developed below need not devolve to a fullthroated embrace of every conceivable libertarian ideal. Some aspects of libertarian orthodoxy will be more applicable to Indian Country than others. The framework that follows reflects this relevance accordingly. While perhaps surprising, this approach is eminently consistent with libertarian theorists - the vast majority of whom embrace the ideal of pragmatism and the need to implement libertarian ideals over time. The effect of this incremental approach is that a libertarian framework for Indian rights can distill the best of libertarian thought, and apply it in a practical way toward extant policy questions facing Indian Country today.

\footnotetext{
${ }^{676}$ See Sowell, supra $\mathrm{n} .547$ at $58-65$.

${ }^{677}$ Kades, supra n.648 at 1109.

${ }^{678}$ See Johnson v. McIntosh, 21 U.S. 542 (1823).
} 


\section{A. Indian Rights and the Role of the State}

The first step in developing this libertarian framework for Indian rights is to revisit the work of Nozick, and Bastiat in order to understand how their contributions apply to Indian Country $^{679}$ and her peoples generally. The following section explores the relevance of Nozick's "utopia" to Indian Country, and how Bastiat's musings on the metes and bounds of government contribute toward an understanding of the goal of "measured separatism."

\section{An Indian View of Utopia}

Revisiting Nozick's work in Anarchy, State, and Utopia, the basic principles of a "minimal state" are the presumptions of 1) individual rights, and 2) the need to protect rights from violation. ${ }^{61}$ In terms of Indian culture, nothing in Nozick's point of departure is in anyway antithetical to Indigenous cultures or customs. In fact, analyzing the matter from a human rights perspective, Nozick's basic ideas are enshrined in the American Declaration of Independence ${ }^{682}$, the U.N. Declaration on the Rights of Indigenous Peoples, ${ }^{683}$ and the International Labor Organization's Convention No. $169 .{ }^{684}$ The obvious, initial application of Nozick's work to Indian Country is two fold. First, Indian peoples are afforded the same human rights under the law as everyone else. Second, the ability to protect their rights from violation is just as important a right as the general presumption that Indians possess human rights. Naturally, it would be quite hollow to guarantee an individual's human rights without affording the person some means of

\footnotetext{
${ }^{679}$ This section freely uses the term "Indian Country" to denote the territory controlled by tribal governments as defined in 18 U.S.C. $\S 1151$ (2012). Previous chapters have also used the term as well, but later discussions of Indian land tenure require me to make a brief explanation here.

${ }^{680}$ See Williams, supra $\mathrm{n} .7$ at xxxvi.

${ }^{681}$ Nozick, supra n.247 at 118.

${ }^{682}$ U.S.C. Declaration of Independence (2012).

${ }^{683}$ United Nations, U.N. Declaration on the Rights of Indigenous Peoples Art. 1, Art. 3 (2007).

${ }^{684}$ International Labor Organization, ILO Convention No. 169, Art. 3, Art. 7 (1989).
} 
protecting them. In this way, Nozick's preliminary assumptions follow logically one from the other.

But Nozick takes the ability to protect rights one step further insofar as he deems it perfectly logical for individuals to freely form associations, or forms of self-government to guard against violations of individual rights. ${ }^{685}$ The result is that the association, government or "minimal state" takes on a more objective role than the whims of individuals for it by default becomes the lone "arbiter of correctness" in the adjudication of disputes over rights. ${ }^{686}$ The implications of Nozick's philosophy for Indian Country are profound. First, one of the criticisms often levied against libertarian thought is that it does not adequately deal with the issue of community, or communal property. But as Nozick's minimal state demonstrates above, his basic presumption is that individuals have the ability and the right to freely associate with one another. ${ }^{677}$ And whatever organization of government that results has the obligation to enforce its "de facto monopoly" over the enforcement of the rights of individuals. ${ }^{68}$ Thus communal property, communal associations, and communal rights need not conflict within a libertarian framework, because libertarian philosophy encourages the free association of individuals. Provided that the minimal state or government enforces rights according to the decisions of the community, there is no conflict between communal rights and libertarian philosophy.

Nozick would guarantee property rights under his framework through the principles of distributive justice noted above. ${ }^{699}$ The basic ethic outlined by Nozick, in effect, amounts to a simplified scheme for property conveyances: 1) A person who acquires a "holding" - broadly interpreted as a piece of property of any sort - through a just acquisition is entitled to the

\footnotetext{
${ }^{685}$ Nozick, supra n.347 at 118.

${ }^{686} \mathrm{Id}$.

${ }^{687} \mathrm{Id}$.

${ }^{688}$ Id.

${ }^{689} \mathrm{Id}$. at 151.
} 
holding; similarly 2) a person who acquires a holding through a just transfer from someone else, is entitled to the holding; finally, 3) holdings, or property can be conveyed only through repetitions of principles 1 and $2 .{ }^{690}$

As the theory applies to Indian Country, Nozick assumes that acquisitions and transfers of property are "just," insofar as "whatever arises from a just situation by just steps is itself just." ${ }^{691}$ This idea, of course, has a great deal of relevance to the expropriation of Indian lands, which are uniformly believed to be unjust by both tribes and tribal advocates. ${ }^{692}$ Assuming the expropriation of Indian lands was unjust, the solution proposed by Nozick is guided by the "principle of rectification of injustice." ${ }^{" 693}$ Under the principle of rectification, such unjust distributions must draw from "the historical information about the previous situations and injustices done," and the actual results that followed the time of the injustice to the present. ${ }^{694}$

In addition to providing a foundation for Indigenous human rights, Nozick's framework for property rights also provides a mechanism for providing reparations to injured parties - all based upon the principles of limited government and free markets. Tribes, no less than any other group of people, have the right to freely associate and establish their own associations for government, so long as they are freely entered, and freely maintained. To the extent that property acquisitions and transfers occur (which is an individual's right), they must be done so according to the principles of distributive justice, thereby validating that the steps of acquisition or transaction are just in their own right. Where such principles are unjust, reparations are required in order to right the balance - taking into account not only the historical wrong, but the

\footnotetext{
${ }^{690} \mathrm{Id}$.

${ }^{691} \mathrm{Id}$.

${ }^{692}$ See Felix S. Cohen, Cohen's Handbook of Federal Indian Law § 1.03 [1] (LexisNexis 2005).

${ }^{693} \mathrm{Id}$. at 152 .

${ }^{694}$ Id. at 152 .
} 
consequence that has followed. Given the length of the Cobell lawsuit and settlement, ${ }^{695}$ and the penchant of the Supreme Court to chip away at the vestiges of tribal sovereignty, ${ }^{696}$ it is safe to conclude that Nozick's libertarian model of governance would be friendlier to tribal interest that the present model wrought under Justice Marshall, placing Indian rights in the hands of an allpowerful Congress. ${ }^{697}$

Finally, it is important to note that Nozick's libertarian philosophy is also friendly toward the goal of tribal "measured separatism," first articulated by Prof. Robert A. Williams of the University of Arizona. ${ }^{698}$ Williams envisions a government-to-government relationship between tribal and federal governments that affords Indians "the right to govern their reservation homelands and those who enter them by their own laws, customs, and traditions, even when these might be incommensurable with the dominant society's values and ways of doing things. ${ }^{~} 699$ Under Nozick's philosophy this outcome is not only plausible, but preferable. Unlike the current Federal Indian Law policy of the United States, Nozick's view of "utopia" is that there is no one, best social ideal for every one. ${ }^{700}$ Rather, there are any number of utopias, or minimal states/self-governments that may exist when like-minded individuals opt to form associations, and governments. ${ }^{701}$ Thus, Nozick's entire philosophical framework for utopia, is actually a framework for utopias - a methodology for implementing diversity, tolerance, and ethics based upon the desires of like individuals to form or join the communities of which they wish to be a part. ${ }^{702}$

\footnotetext{
${ }^{695}$ See P.L. 111-291, Dec. 8, 2010.

${ }^{696}$ See City of Sherrill v. Oneida Indian Nation of N.Y., 544 U.S. 197, 214 (2005).

${ }^{697}$ See Lone Wolf V. Hitchcock, 187 U.S. 553, 564-564 (1903).

${ }^{698}$ See Williams, supra $\mathrm{n} .7$ at $\mathrm{xxxv}$.

${ }^{699}$ Id.

${ }^{700}$ Nozick, supra n.347 at 310.

${ }^{701}$ Id.

${ }^{702}$ Id. at $311-312$.
} 
For Indian Country, such a framework is profound. Rather than relying upon the principles of Federal Indian law, libertarian thought offers a model for tribal self-governance and tribal sovereignty that is based simply upon the will of likeminded individuals to freely associate with one another. Simply put, a libertarian framework of Indians rights assumes that individuals have rights, including the right to freely associate, and that no imposition can be made upon peoples who choose to freely live in community with one another. ${ }^{703}$ The lone common ground between groups of freely associating individuals is the framework of a utopia of utopias itself. ${ }^{704}$ Each band of peoples must respect the existence of other peoples because mutual respect and tolerance is what ensures the perpetuity of the system. ${ }^{705}$

As Nozick admits, his vision is a fantasy at this point. ${ }^{706}$ But the framework of utopias is important to Indian Country because it describes a new system for promoting tolerance and selfdetermination that is not rooted in the principles of modern Federal Indian Law. ${ }^{707}$ Even more important for the present discussion is that Nozick's vision is one that can be implemented over time. While Nozick's system would undoubtedly portend systemic changes to the relationship between tribal, federal and state governments over the long-term, Indian advocates need not argue for a wholesale implementation of Nozick's system. The incremental nature of libertarian philosophy allows for a much more expedient approach to change through advancing policy positions that are consistent with a view buttressing the rights of individual Indians, and the attendant notion that such rights should be protected under the law. From there, the rights of free association, and tribal self-determination follow as a matter of course, allowing measured separatism to become the byproduct of an assertion individual rights.

\footnotetext{
${ }^{703} I d$. at 316.

${ }^{704} \mathrm{Id}$. at 317.

${ }^{705}$ Id.

${ }^{706} \mathrm{Id}$. at 308 .

${ }^{707} \mathrm{Id}$.
} 


\section{The Libertarian Ethic of Indian Rights}

Nozick's ideas provide a sweeping framework for Indian rights based upon libertarian principles. But what Nozick offers in scope, he lacks in detail. In this regard, the contribution of Frederick Bastiat is of paramount importance for creating a libertarian framework for Indian rights.

Bastiat's greatest contribution toward a libertarian framework for Indian rights is his ethic of rights and law. ${ }^{708}$ The ethic is elegant for its simplicity: law cannot "be used to destroy the person, liberty, or property of individuals or groups." ${ }^{709}$ Any violation of this simple maxim is considered to be a "complete perversion of law." $" 710$ The sole role of government under Bastiat's principle is to prevent injuries to the rights outlined in his ethic from occurring. ${ }^{711}$ When violations of the norm do occur, Bastiat calls the offense plunder - whether illegally wrought by individuals, or lawfully wrought by government. ${ }^{712}$ The consequence for violations of Bastiat's ethic include the abolishment of all laws permitting legal plunder, and reparations that restore what was taken from individuals - preferably at the expense of the party committing the offense. ${ }^{713}$

Regarding Indian Country, it is not difficult to find scores of violations of Bastiat's ethic, making Bastiat a sympathetic if not surprising ally. First, law was repeatedly used as an instrument of control not only to undermine Indigenous concepts of identity, but also in the abject expropriation of Indian lands. ${ }^{714}$ Naturally, Bastiat would interpret this as a perversion of

${ }^{708}$ Bastiat, supra n.250 at 2.

${ }^{709} \mathrm{Id}$.

${ }^{710} I d$. at 4.

$711 \mathrm{Id}$. at 25

${ }^{712}$ Id. at 7.

${ }^{713} \mathrm{Id}$. at 17.

${ }^{714}$ See supra Ch. 2; See also Ward Churchill, Kill the Indian, Save the Man: the Genocidal Impact of American Indian Residential Schools (City Light Books 2004); Vine Deloria Jr., God is Red: a Native View of Religion, 271 
law and a deviation from its intended purpose of preventing violations of rights to persons, liberty and property. ${ }^{715}$ In terms of consequence, Bastiat's ethic clearly requires some form of positivist action on the part of government for any laws that resulted in harm depriving Indigenous peoples of their right to life, freedom, or property - whether communal or individual. ${ }^{716}$

One interesting point about Bastiat's ethic is the degree to which it protects Indian property rights. Under the Marshall Model of Indian rights, Indians were originally forbidden from filing suit for claims alleging compensable takings of Indian lands altogether. ${ }^{717}$ And while the passage of the Indian Claims Commission Act of 1946 sought to rectify this inequality, tribes were still not permitted to obtain awards of interest for their claims against the United States, leaving equipoise an unrealized goal. ${ }^{718}$ Bastiat's libertarian ethic, by contrast, not only calls for the abolition of laws that lead to such unequal outcomes, but it also assumes that recompose will be made to those parties who have had their rights to life, property, or personhood injured. ${ }^{719}$

Here again, the libertarian ethic of rights is much more friendly toward rectifying historic injustices committed against Indian tribes than the current framework of Indian rights under the Marshall Model. In contrast to those skeptical of private property rights, ${ }^{720}$ Bastiat's ethic is not only friendly toward communal forms of property ownership, ${ }^{721}$ but he also argues at length of the right of individuals to freely associate in providing for its defense, thereby indicating a

(Fulcrum Pub. 2003). Robert A. Williams, Like a Loaded Weapon: The Rehnquist Court, Indian Rights, and the Legal History of Racism in America, 22 (U. Minn. Press 2005).

${ }_{715}$ Bastiat, supra n.379 at 4.

${ }^{716} \mathrm{Id}$. at 2 .

${ }^{717}$ See 37 Cong. Ch. 92, March 3, 1863, 12 Stat. 765 (1863).

${ }^{718}$ See 79 Cong. Ch. 959, August 13, 1946, 60 Stat. 1049 (1946).

${ }^{719}$ Bastiat, supra n.379 at 7.

${ }^{720}$ See U.S. v. White Mountain Apache Tribe, 537 U.S. 465 (2003).

${ }^{721} I d$. at 2 . 
willingness to accept tribal institutions and communal associations. ${ }^{722}$ His acceptance of both communal property, and free association, only underscore Bastiat's willingness to use the force of law to restore justice when rights are violated. ${ }^{723}$

\section{B. The Role of Freedom in Securing Indian Rights}

To recap, Nozick's vision of utopia provides a working structure to our libertarian framework for Indian rights by creating a system of relationship and balance that provides ample tolerance for tribal governments and institutions, and the communal or individual ownership of property. From Bastiat, our libertarian framework for Indian rights gains a normative basis rooted in the right to personhood, the right to freedom, and the right to property, whether owned communally, or individually. Bastiat's role for government is to protect these three rights from abuse, with the understanding that any violation of the above should result in an equal application of the force of law to redress the harm. Given the framework established Nozick, and the normative foundation provided by Bastiat, the works of Hayek, Locke, and Popper illuminate the role of freedom and its operation within our framework for Indian rights.

\section{Realizing Freedom in Indian Country}

As noted in Chapter Four, F.A. Hayek's analysis of social and governmental institutions focuses extensively on the normative importance of freedom and its role in generating society's moral values. ${ }^{724}$ Hayek's concept of freedom is expansive, consisting of two equal principles that ensure an individual's realization of freedom. His first principle of freedom involves a quantitative assessment of the degree to which individual is free from outside coercion. ${ }^{725}$ His second and corollary principle of freedom qualitatively analyzes the extent to which an

722 Id.

${ }^{723} \mathrm{Id}$. at 69.

${ }^{724}$ Hayek, supra n.379 at 5.

${ }^{725} \mathrm{Id}$. at 11 . 
individual can "expect to shape his course of action in accordance with his present intentions, or whether somebody else has power so to manipulate the conditions to make him act according to that person's will rather than his own. ${ }^{9726}$ While Hayek is realist about the adoption of freedom across societies, ${ }^{727}$ he is nonetheless optimistic about the potential effects that freedom can have in promoting equality under the law ${ }^{728}$ - a freedom that allows for individuals to succeed based upon their own capacities. ${ }^{729}$ To state matters a bit more simply, Hayek's role of freedom in society is not to assure everyone a particular outcome, rather that individuals should be free "to decide what use we shall make of the circumstances in which we find ourselves." ${ }^{\circ 30}$ In light of the primacy Hayek places on freedom, he reduces the role of government to that of a guardian an institution that must use its power of coercion to protect the private sphere, and to create conditions whereby individuals can pursue their own opportunities with only minimum coercion from the government itself. ${ }^{731}$ Given such a limited role of government, it is important to note that Hayek's skepticism of governmental coercion is rooted in an epistemological uncertainty about the ability of human beings to anticipate social problems, and address them adequately.

His solution to the dilemma is the widespread promotion of Liberty. Hayek writes:

"Liberty is essential in order to leave room for the unforeseeable and unpredictable; we want it because we have learned to expect from it the opportunity of realizing many of our aims. It is because every individual knows so little and, in particular, because we rarely know which of us knows best that we trust the independent and competitive efforts of many to induce the emergence of what we shall want when we see it." ${ }^{\text {"732 }}$

\footnotetext{
${ }^{726} \mathrm{Id}$. at 13 .

${ }^{727}$ Id. at 12 .

${ }^{728} \mathrm{Id}$. at 85 .

${ }^{729} \mathrm{Id}$. at 92.

${ }^{730} \mathrm{Id}$. at $19-20$.

${ }^{731} \mathrm{Id}$.

${ }^{732} \mathrm{Id}$. at 29.
} 
In other words, government knows relatively little when it comes to prognosticating the human experience - better to leave it up to individuals to chart their own way, while allowing them ample freedom to accomplish their respective objectives.

Hayek's vision of liberty has manifold implications for realizing true freedom in Indian Country. Readers may recall the assertion by Katherine Wise that American Indians are among the Nation's most heavily regulated peoples. ${ }^{73}$ Given that an entire Federal office has existed in some form or another since the Nation's founding to regulate the affairs of Indians, ${ }^{734}$ one obvious implication is that Indians have never really enjoyed the type of freedom from coercion that Hayek describes so eloquently. ${ }^{735}$ A second implication involves Hayek's qualitative definition of freedom, seeking to capture the extent to which individuals, or in this case American Indians, can shape their courses of action without a higher power seeking to "manipulate the conditions to make [them] act according to that person's will rather than [their] own." ${ }^{\text {736 }}$ Here again, Hayek's qualitative understanding of freedom applied to Federal Indian policy hardly fares better than the application of his quantitative understanding. Ever since the advent of the Congressional Plenary power doctrine over Indian affairs in the late $1880 \mathrm{~s}$, American Indians have always lived under the watchful, if not heavy hand, of the Federal Government - a higher power that possesses an absolute authority to make laws, rules and regulations on behalf of Indian Nations with relative impunity. ${ }^{737}$ Even in its best light, the current state of freedom for most tribal nations remains a myth inscribed by the hand of a jurispathic Court. ${ }^{738}$

\footnotetext{
${ }^{733}$ Wise, supra n.6 at 168.

${ }^{734}$ See today's U.S. Bureau of Indian Affairs, http://www.bia.gov/ (accessed Feb. 25, 2012).

${ }^{735}$ Hayek, supra n.379 at 11.

${ }^{736} \mathrm{Id}$. at 13 .

${ }^{737}$ See U.S. v. Kagama, 118 U.S. 375, 379-380 (1886)

${ }^{738}$ See Williams, supra n.7 at 21.
} 
Regarding Hayek's views of equality, he describes the role of freedom as being one that guarantees individuals the opportunity to decide what to make of one's circumstances. ${ }^{739}$ While it might be fairly argued that various acts of Congress have been passed with precisely this aim, albeit with mixed results, ${ }^{740}$ it remains true of late that the Trust Doctrine has been far more used by Congress as a sword for encroachment upon tribal existence, rather than as a shield for protecting Indian interests. ${ }^{741}$ If there is a lesson to be gleaned from the encroachment of the Federal Government upon tribes, and the history of Federal Indian policy, it is that Hayek's skepticism of restrictions on freedom is well founded. The Federal Government, in its various intrigues related to Indian policy, has repeatedly demonstrated the pitfalls of creating any onesize-fits-all national policy toward American Indians, the lot of whom remain intrinsically diverse from one another despite repeated attempts by the Federal Government to culturally assimilate them.

\section{Indian Rights, Locke, and a Surprising Defense of Native Title}

While Hayek views freedom through a normative lens of the values it creates in society, a view placing him at odds with the view of freedom accorded to American Indians in the courts of the United States, John Locke's view of freedom takes matters further still, attacking some of the foundational assumptions made by the courts with which Hayek disagrees.

It should first be noted, however, that Locke is not an obvious ally of Indian Rights, libertarian or otherwise. His writings about slavery would seem to preclude American Indians from the ranks of those upon whom he would endow with the inalienable right of freedom. One particularly troublesome passage reads as follows:

\footnotetext{
${ }^{739}$ Hayek, supra n.379 at $19-20$.

${ }^{740}$ See The Native American Graves Protection and Repatriation Act, 25 U.S.C. $\S 3001$ et seq (1990), The Indian Reorganization Act, 25 U.S.C. $\S 461$ et seq (1934), The Indian Child Welfare Act, 25 U.S.C. $\$ 1901$ et seq (1978), The Indian Self-Determination and Education Assistance Act, 25 U.S.C. $\S 450$ et seq (1975), etc.

${ }^{741}$ Canby, supra n.140 at $39-51$.
} 
"This is the perfect condition of slavery, which is nothing else, but the state of war continued, between a lawful conqueror and a captive: for if once compact enter between them, and make an agreement for a limited power on the one side, and obedience on the other, the state of war and slavery ceases as long as the compact endures." ${ }^{742}$

What is clear from the passage is that Locke was comfortable with a might makes right approach to conquest in particular, and slavery secondarily. The paragraph indicates that conquered American Indians could avoid slavery by maintaining the terms of their surrender, although the section does not indicate the status of those who refused to surrender for they could hardly be considered slaves in the conventional sense of the term. ${ }^{743}$

While Locke's view of the law of conquest no longer squares with modern notions of international human rights, ${ }^{744}$ an antiquated view of slavery and conquest do not amount to a negation of Locke's inspirational views of freedom, the powerful arguments he makes against both plenary power, and the latent ambiguity he brings to the discussion of Native title. On these latter points, this section will demonstrate that Locke was right in his assessment of plenary power and native title, even if he was wrong in his application of the principles.

First, Locke's Second Treatise of Government begins with a basic presumption of equality and an attendant prohibition against harming the "life, health, liberty, or possessions" of others. ${ }^{745}$ In addition to these fairly ubiquitous rights, Locke leaves individuals the option to form general associations to protect their rights, often taking the form of the commonwealth. ${ }^{746}$ While Locke is quick to affirm the right of individuals to freely associate, his skepticism of centralized authority is never far from his philosophical analysis. Locke takes particular issue with plenary

\footnotetext{
${ }^{742}$ Locke, supra n.348 at 17.

${ }^{743}$ For more on perceptions of Locke's "hypocrisy" see James Farr's seminal essay So Vile and Miserable an Estate: The Problem of Slavery in Locke's Political Thought, 14 Political Theory 2, 263-289 (May 1986).

${ }^{744}$ See United Nations, Supra n.552.

${ }^{745}$ Locke, supra n.348 at 8-9.

${ }^{746} \mathrm{Id}$. at 48 .
} 
power, dubbing the absolute monarchy as an arcane institution that is utterly inconsistent with civil government. $^{747}$

What is perhaps most surprising about Locke's views for the purposes of this libertarian framework for Indian rights is the contempt Locke held for the right to govern by virtue of conquest. Quite in contrast to Locke's theory of slavery above, Locke firmly believed that a government could only be legitimate if it was founded with the consent of the people over which it would rule, noting that conquest itself was an insufficient right to rule. ${ }^{748} \mathrm{In}$ an especially powerful example, Locke compared government by conquest to a robber invading a home, and demanding just title to the estate. ${ }^{749}$ It is not at all clear that Locke had Indian title in mind, when he sketched his analogy, but the truth of his assessment is even more powerful for its prescience than its reflection of Locke's actual view and acceptance of his example as truth. Elsewhere, Locke argues that even where a conqueror obtains power in a "just war" the spoils of which provide him with a "despotical power," he still "has not yet thereby a right and title to their possessions." ${ }^{9750}$

Locke's contribution to this libertarian framework of Indian right is that he articulates principles of freedom, and governance that are objectively correct and relevant to today's administration of governance, even if he did not intend to include Indians under his framework. Locke viewed plenary power as an especially pernicious evil, disclaiming it as wholly inconsistent with civil forms of government. ${ }^{751}$ This view is not far afield of many Indian rights advocates and critical theorists discussed in Chapter 3. In addition, Locke makes a powerful argument against the Doctrine of Discovery as handed down through the Marshall Court, even if

\footnotetext{
${ }^{747} \mathrm{Id}$.

${ }^{748} \mathrm{Id}$. at 91 .

${ }^{749} \mathrm{Id}$.

${ }^{750} \mathrm{Id}$. at $93-94$.

${ }^{751}$ Id. at 48 .
} 
he intended to restrict his argument to Europeans alone. Locke argued that governments found legitimacy through consent rather than conquest, and quickly noted that conquest alone did not grant title to the conquerors. ${ }^{752}$ While it is unlikely that Locke intended this maxim to apply to Indians, and perhaps a great deal of evidence to suggest that he did not, this does not make the statement any less true. After applying our contemporary notions of personhood and the general acceptance of democratic systems of governance to Locke's views of right to title, the result is a rehabilitated view of Locke that co-opts his perspective from the confines of his age. Thus, Locke's railings against invading forces demanding title to conquered lands, ${ }^{753}$ become something that Indian Country can embrace. To put matters differently, Locke was correct in his normative assessment both of plenary power and conquest even if he did not realize the logical end to which his ideas could be taken.

\section{Popper's Deconstruction of Plenary Power}

Karl Popper's work in The Open Society and Its Enemies is an interesting polemic against the dangers of centralized power. ${ }^{754}$ While the work delves a bit into the philosophical weeds for our purposes (exploring "the Platonic theory of justice and the theory and practice of modern totalitarianism."), ${ }^{755}$ it nonetheless provides an important argument about the myth of plenary power. Popper notes that even though absolute power may exist as a legal fiction, it is nonetheless a myth in reality because of the numerous institutional mechanisms necessary to exert power over the subject. ${ }^{756}$ From this conclusion Popper further argues that "open society" must implement "checks and balances" 757 to ensure that institutional frameworks can be

\footnotetext{
752 Id. at 91.

${ }^{753} I$ Id.

${ }^{754} I d$.

${ }^{755}$ Popper, supra n.444 at 5.

${ }^{756}$ Id. at $121-122$.

${ }^{757}$ Id. at 122 .
} 
reformed to reflect democratic principles ${ }^{758}$ This self-oversight is crucial, since under Popper's framework, free people are the guardians of their own rights. ${ }^{759}$ As for the actual implementation of institutional reforms, Popper's advice is that any bureaucratic and policy modifications be made through "piecemeal engineering." ${ }^{, 760}$ Given the penchant for grand plans to fail, Popper argues that society is better off performing a sort of social triage to address the most pressing problems of the day, and implementing policy solutions to address those issues first. ${ }^{761}$

Finally, in his second volume on the open society, Popper takes issue with the emerging (and indeed still emerging) trend of nationalism, dismissing such movements as nothing more than radical collectivism. ${ }^{762}$ Popper not only questions the commonly held assumption of the utility of the nation-state, but also muses about alternative forms of national identity, such as geography, political creed, and even religion. ${ }^{763}$ Such visions of nationhood that define a state based upon a geographical area, Popper rejects as nothing more than romanticism run amuck..$^{764}$

Popper's work has several important implications for our libertarian framework for Indian rights. First, Popper deftly proves that centralized, absolute power, or plenary power as it applied to Indian law is nothing more than legal fiction, or myth. ${ }^{765}$ Even while Congress may pass laws affecting Indian affairs, it takes the work of the Executive Branch to carryout the legal mandate and the active effort of the Judicial Branch to remove challenges to such Congressional fiats from its docket, thereby reinforcing the regime of plenary power. But even where systems have come to be morally askance of modern notions of justice, Popper offers the simple reminder that in free societies, institutions can be reformed through by "the people" through the

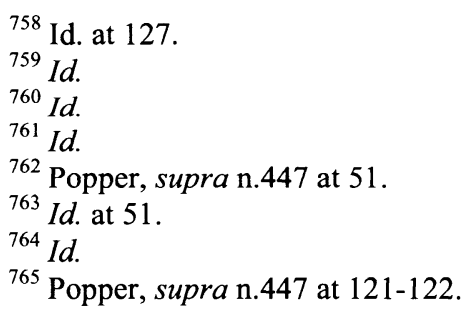


implementation of "checks and balances" on the system. ${ }^{766}$ Assuming Congress has plenary power over Indian affairs, the enthymeme Popper suggests is that Congress also has the authority to reform the system of Indian rights to comport with modern notions of freedom, justice, and equality. Similarly, while courts may continue to enforce the racist language of their precedents dating from the $19^{\text {th }}$ Century, ${ }^{767}$ institutional frameworks and moral aberrations of law can be updated through the institutional checks and balances of the legislature to reflect modern notions of justice. ${ }^{768}$ Note, that Popper never said this would be an easy undertaking, but it is an important reminder that the potential for reform within the legislative system is an obvious check on the judiciary.

Even when reforming governmental institutions is desirable, Popper advises an incremental approach to the process - or what he calls "piecemeal engineering." ${ }^{769}$ Given the various experiments in Federal Indian policy - ranging from the General Allotment Act, which decimated the trial land base, ${ }^{770}$ to the era of Termination, which sought to end the status of American Indians as wards of the Government, ${ }^{771}$ it seems obvious if not safe to say that major programs aimed at Indian Country tend to do more harm than good. In fact, many recent policy successes related to Indian Nations have been relatively modest in scope, indicating that measured legislation to specific policy issues is perhaps the better route. ${ }^{772}$

Finally, Popper's railing against nationalism commends a strikingly progressive understanding of modern multiculturalism. ${ }^{773}$ This suggests for Indian Country that any libertarian framework for Indian rights must include a right to maintain tribal identities without

\footnotetext{
${ }^{766} \mathrm{Id}$. at 122 .

${ }^{767}$ See Williams, supra $\mathrm{n} .7$ at 100.

${ }^{768}$ Popper, supra n.447. at 127.

${ }^{769} \mathrm{Id}$. at $158-159$.

${ }^{770}$ Canby, supra n. 140 at 22.

${ }^{771} \mathrm{Id}$. at $27-30$.

${ }^{772}$ See supra n.740.

${ }^{773}$ Popper, supra. n.447 at 51.
} 
the risk of suppression from the state. ${ }^{774}$ Of course, this has not always been the case in the U.S., particularly in light of attempts at assimilation under the General Allotment Act, but Popper's recognition of the importance of maintaining cultures and traditions, underscores how a libertarian framework for rights differs dramatically from the legacy left by the Marshall Model.

\section{The Market and Indian Country}

The final component of a libertarian framework for Indian rights is the operation of free markets within Indian Country. Recall that Nozick's utopia provided a working structure for the framework by demonstrating how tribal governments can maintain a degree of measured separatism vis-à-vis states and the Federal government based upon the right of free individuals to freely associate with whom they would. Bastiat builds on this model by providing a normative justification for Nozick's utopia that affirms the basic rights of personhood, freedom, and property. Under his ethic, the power of law is constrained to the protection of these rights alone.

From our discussion of freedom, Hayek shows how governmental coercion hinders the ability of individuals and groups of individuals to enjoy their basic right to freedom and shape their courses of action. The misadventures of Federal Indian policy provide ample evidence to support Hayek's theory as it applies to Indian Country. Similarly, while Locke's record has been criticized for its antiquated embrace of slavery, his attack on governmental power by conquest was far ahead of its time and remains applicable to Indian Country today. Even more important than his mistrust of conquest and might-makes-right governance was Locke's skepticism of plenary power. In the experience of American Indians, given the various, forced relocations of numerous Indian tribes, and the authority of Congress to unilaterally abrogate treaties without

\footnotetext{
${ }^{774}$ See, e.g., revisions to 25 U.S.C. $\S 81$ (2012) as an example of the right to maintain tribal identities without the risk of state suppression.
} 
input from the Indian parties affected, Locke's suspicion of plenary power has proven to be well founded. ${ }^{775}$

Finally, where Locke's thoughts on freedom end with a disdain for plenary power - one of the pillars of modern Federal Indian Law - Popper's contribution to our libertarian framework for Indian rights builds on Locke's work by offering a complete deconstruction of plenary power itself. Under Popper's theory the plenary power of Congress over Indian affairs is a farce given all the many bureaucracies involved in enforcing its Indian policies. And even while Congress wields considerable power over Indian affairs, Popper undermines the notion through the recognition of checks and balances, both through the political process, and through the ability of individuals within the system to seek reforms. To the extent that changes are sought in Federal Indian policy, Popper would caution against sweeping programs, for want of specific policy proposals to address specific issues - a view that is at least partly informed by his understanding of the importance of cultural preservation as opposed to widespread nationalism; and the understanding that different tribes have different needs - that there is no one-size-fits-all Indian policy.

Having discussed the role of government, and freedom within a libertarian framework for Indian rights, the remaining part of the analysis requires a discussion of the importance of markets within the new model. The following sections will apply the work of Adam Smith, Milton Friedman, Thomas Sowell, Hernando De Soto, and Ayn Rand to the libertarian framework for Indian rights.

${ }^{775}$ See Lone Wolf v. Hitchcock, 187 U.S. 553 (1903). 


\section{Building the Service Economy in Indian Country}

The major contribution of Adam Smith's Wealth of Nations to the libertarian framework for Indian rights is its emphasis of service-based economies as a means of generating wealth. ${ }^{776}$ Smith's philosophical point was that freedom could not be realized apart from the economic capability of living one's life how one would. For the service economy, this meant that even individuals with the least of skills could still perform some service, and that a number of individuals could provide goods or produce services much more efficiently when working in concert. ${ }^{777}$ In turn, Smith reasoned that as the service-based economy grows, wealth spreads by allowing people even of the "lowest ranks" to participate, earn a wage, and live life on their own terms through economic freedom. ${ }^{778}$ Regarding the origins of the service economy, Smith argued that the simple desire of an individual to procure a profit was sufficient to buttress entire economies of nations, rather than implementing command-control systems of production. ${ }^{779}$ Regarding the role of government in the process, Smith's vision of society limited government to three very specific functions: protection from violence, guarding against injustices and oppression, and establishing public institutions for the general benefit of society. ${ }^{780}$ Perhaps unsurprisingly, he was also highly skeptical of various schemes for taxation, arguing that taxes should take as little as possible from citizens beyond the necessary expenses for the operation of government. ${ }^{781}$ Smith was particularly concerned about the potential of taxes to bankroll bloated bureaucracies, to stifle innovation and discourage entrepreneurship, and to create opportunities for public corruption. ${ }^{782}$

\footnotetext{
${ }^{776}$ Smith, supra n.477 at 9.

${ }^{777}$ Id.

${ }^{778} \mathrm{Id}$. at 15.

${ }^{779} \mathrm{Id}$. at 19.

${ }^{780} \mathrm{Id}$. at 446

${ }^{781}$ Id. at 478.

${ }^{782}$ Id. at $478-479$.
} 
The implications of Smith's work for Indian Country are manifold. The most important extension of Smith's logic to our libertarian framework for Indian rights is the importance of developing a tribal service-based economy as a means of generating wealth for American Indians. ${ }^{783}$ While strides have been made in recent years to promote economic development in Indian Country, most tribal nations have lagged behind Smith's vision of service economies even as much of the world (including the developing nations) has embraced the ideal. According to the Harvard Project on American Indian Economic Development, American Indian reservations are consistently among the "poorest identifiable" groups in the U.S, ${ }^{784}$ and while the Indigenous private sector has made impressive gains, Indian entrepreneurs are still hampered by the process of starting small businesses on the reservation due to the institutional absence of "basic zoning ordinances, land use plans, physical infrastructure, and streamlined leasing arrangements." Even while the role of government may not be so neatly constrained to Smith's view, it is clear that the development of a service-based economy in Indian Country remains a challenge for many Indians and tribes across the Nation.

A second implication of Smith's theory is the need to develop business friendly environments across Indian Country. Smith's entire service-based economy is premised upon the opportunity for quite nearly anyone to perform a service and perform a wage. ${ }^{786}$ Of course, as the modern economy has grown more complex in the production of goods, Indian nations hampered by the regulations of Federal and state governments alike have struggled to create conditions that are "conducive to business within their nations." ${ }^{1787}$ But as Smith's descriptions indicate, such a climate is necessary in order to attract investment capital, grow tax revenue from businesses, and

\footnotetext{
${ }^{783}$ Smith, supra n.477 at 9.

${ }^{784}$ Harvard Project on American Indian Economic Development, supra n. 10 at 7.

${ }^{785} \mathrm{Id}$. at 129.

${ }^{786}$ Smith, supra. n.477 at 15.

${ }^{787}$ Harvard Project on American Indian Economic Development, supra n.10 at 128.
} 
improve the quality of life in Indian Country. ${ }^{788}$ In order to develop Smith's service-based economy, tribal nations must provide a climate in which they can grow.

Another implication for our libertarian framework for Indian rights from Smith's work is the importance of the private sector in promoting freedom. While the point may seem stark, command-control economics have not worked in Indian Country because they stifle the opportunity for individual entrepreneurs to provide unique services. ${ }^{789}$ Regarding economic development in Indian Country today, private sector Indian entrepreneurs tend to complement tribally-owned businesses on the reservation, contributing to the local economy through tax revenues, the retention of human capital, and most importantly providing jobs in the community. ${ }^{790}$

Finally, Smith's model suggests that a libertarian framework for Indian rights provide for a tax scheme that takes as little as possible from its citizens. ${ }^{791}$ Tribal Nations like modern governments can be tempted to enact stifling tax polices in order to provide any number of services for tribal members. But Smith's insight was that the latent snares of taxation (bloated bureaucracies, stifled innovation and entrepreneurship, and public corruption) all pale in comparison to a simple tax scheme that funds only the most essential services while providing for a maximization of opportunity for the citizenry. ${ }^{792}$

\section{Indians and the Weapon of Choice}

While Adam Smith's chief insight was his ruminations about the service economy, Milton Friedman's contribution to our libertarian framework for Indian rights is his

\footnotetext{
${ }^{788} \mathrm{Id}$. at 129.

${ }^{789}$ Smith, supra $\mathrm{n} .477$ at 19.

${ }^{790}$ Harvard Project on American Indian Economic Development, supra n.10 at 129.

${ }^{791}$ Smith, supra n. 477 at 478.

${ }^{792}$ Id. at $478-479$.
} 
understanding of the correlation between economic and political freedom. ${ }^{793} \mathrm{He}$ begins his argument by describing the social benefits of markets arising from voluntary transactions between buyers and sellers. Markets are important, he argues, because they efficiently transmit information to interested parties about goods and services, thereby allowing buyers and sellers to arrive at an agreeable price ${ }^{794}$ According to Friedman this creates an incentive for both parties to act, establishing an acceptable balance between supply and demand for the goods. ${ }^{795}$ Finally, Friedman argues that markets and the transactions taking place within them create an effective system for the societal distribution of income - a system that is not only effective, but also more efficient than any method of centralized planning. ${ }^{796}$

The unspoken key to making Freidman's concept of markets work is the dual elements of chance and choice affecting individuals within the market. ${ }^{797}$ While one's chances for economic opportunity may be limited within a market depending upon one's family, appearance, mental ability, and even culture, Friedman argues that it is the choices made by individuals that determine whether one's wealth increases or decreases. ${ }^{798}$ In other words, economic freedom and eventually economic opportunity depend upon individuals having a freedom to choose. ${ }^{799}$ Implicit in his analysis of choice is the idea that voluntary cooperation in markets occurs because individuals are making such choices and determinations based upon their self-interests ${ }^{800} \mathrm{His}$ construction of the term is fairly broad, ranging from obvious pecuniary incentives to the broader motivation of whatever an individual values, and seeks to pursue. ${ }^{801}$

\footnotetext{
${ }^{793}$ Friedman, supra n.492 at 2.

${ }^{794}$ Id.

${ }^{795} \mathrm{Id}$.

${ }^{796} \mathrm{Id}$. at 22.

${ }^{797} \mathrm{Id}$.

${ }^{798} \mathrm{Id}$.

${ }^{799} \mathrm{Id}$.

${ }^{800} \mathrm{Id}$. at $26-27$.

${ }^{801}$ Id.
} 
Friedman's view of the role of government in the operations of markets largely mirrors that of Smith, that is to say he views a fairly minimal role for government in the operation of markets. ${ }^{802}$ Regarding governmental intervention, it is noteworthy that Friedman argues for a "burden of proof" justifying the government action that is placed on the proponents of a measure, creating a default presumption against government action absent some compelling reason. ${ }^{803}$ Accordingly, Friedman attacks the modern regulatory and administrative state with vigor, railing against tyrannical controls over markets, and the dizzying array of regulations that makes businesses difficult to thrive ${ }^{804}$ Regarding free trade, Friedman argues for a large-scale reduction of trade restrictions and tariffs, ${ }^{805}$ which is eminently consistent with his broader view that centralized planning of any sort limits the ability of individuals to maximize their personal liberty and economic freedom. ${ }^{806}$

Like Adam Smith, Friedman's theories have many implications for a libertarian framework for Indian rights. His first implication for Indian Country is that actual freedom must be realized by economic freedom. Without the unbridled capacity to make decisions about their economic lot American Indians will not truly benefit from what Fatboy Slim famously (or infamously) called "the weapon of choice." ${ }^{807}$ For Friedman, this involves the informed and active participation in a price system that is driven by mutually beneficial interactions within the market. ${ }^{808}$ Obviously, mutually beneficial interactions depend upon parties being able to assert their self-interest in market transactions. Friedman, of course, interprets the term self-interest broadly to include whatever motivates individuals in a transaction - whether it be simple desire

\footnotetext{
${ }^{802}$ Id. at $29-30$.

${ }^{803} \mathrm{Id}$. at $31-32$.

${ }^{804}$ Id. at $38-39$.

${ }^{805}$ Id. at 39.

${ }^{806} \mathrm{Id}$. at 65.

${ }^{807}$ See Fatboy Slim, Weapon of Choice, http://www.youtube.com/watch? $\mathrm{v}=\mathrm{oF} 5 \mathrm{cBoAV} 5 \mathrm{Ys}$ (accessed Feb. 29, 2012).

${ }^{808}$ Friedman, supra n.492 at 26.
} 
to turn a profit, or the values that define a community, or whatever objective people or peoples wish to pursue. ${ }^{809}$ In this way, the pursuit of self-interest is eminently commensurable with tribal societies, provided that the motivation of tribes or tribal peoples is consistent with the values and aims of the community. Friedman's weapon of choice does not guarantee communal outcomes, but it does afford individuals motivated by communal values the opportunity to pursue the interest of their communities.

Regarding markets in Indian Country, Friedman's analysis not only suggests that they are important, but that they are imperative if the dual goals of personal and economic freedom are to be realized. Friedman's view of the benefits of markets are relevant to Indian Country in the same way that they are relevant to the global economy: 1) Prices transmit information to interested parties; ${ }^{810}$ 2) Prices provide an incentive to buyers and sellers to react to the information provided; ${ }^{811}$ and 3) The exchange of goods or services aids in the process of economic distribution. ${ }^{812}$ For Indian Country, this means that rather than having to travel several miles away form the reservation or community, goods and services can be produced and provided by other members of the community, allowing for a more efficient distribution of wealth. This provides sellers an opportunity to serve the community with their products, and offers buyers the opportunity to conveniently acquire goods and services without a lengthy delay that they might otherwise have been unable to avoid. Of course, the market place described above also affords Indians the opportunity to export their goods assuming they have some sort of comparative advantage, but even more important than this is the fact that the market in Indian Country depends upon the ability of American Indians to actually make free choices as to how

${ }^{809} I d$.

${ }^{810} I d$. at 15 .

${ }^{811}$ Id. at 18 .

${ }^{812}$ Id. at 20. 
they would allocate their resources. Friedman's model assumes that "chance" provides some advantages and disadvantages to participants in the market, but this is redeemed by the potential of individuals to make good choices based upon their economic self-interest. ${ }^{813}$ Absent meaningful choices, such as the opportunity to freely alienate land, control over natural resources, the ability to manage projects and investment opportunities, tribal nations will not, and cannot participate meaningfully in the market. $^{814}$

Finally, Friedman's weapon of choice, and his view of markets, suggests that Indian Country and its governments must cultivate a climate of opportunity that rewards creativity and innovation, and maximizes choice rather than restricting it. Friedman's concerns about the "tyranny of controls" and the restrictions and restraints on investment and capitalization all indicate that developing economies need time and opportunity to grow without interference from governments - whether the government be tribal, state, or federal..$^{815}$

\section{Developing Meaningful Indian Property Rights}

While Milton Friedman ably delineated the relationship between economic and political freedom, Thomas Sowell's discussion of property rights in Basic Economics explains why meaningful property rights are necessary to both individuals and the economy in the aggregate. ${ }^{816}$ Sowell's basic argument is that property rights delineate the ways in which resources can be put to beneficial use and allocated. ${ }^{817}$ Such a system is crucial because it provides incentives for owners to maintain a system of self-monitoring of their property in order to ensure future

\footnotetext{
${ }^{813} I$ d.

${ }^{814}$ Harvard Project on American Indian Economic Development, supra n. 10 at 135.

${ }^{815} \mathrm{Id}$. at $38-39$.

${ }^{816}$ Sowell, supra $\mathrm{n} .547$ at 422.

${ }^{817}$ Id. at 422.
} 
profits. ${ }^{818}$ Of course, the potential for future profits from sales of property assumes that property is alienable and that the property owner has actual title to his or her property. ${ }^{819}$

Regarding the role of government in Sowell's essay property rights, his assertion is that owners have a self-interest to ensure the quality production of goods. ${ }^{820}$ Using the example of McDonald's he argues that a sustainable supply of cattle is necessary to ensure continued profit for the corporation. ${ }^{821}$ Thus, self-monitoring as a function of property owners pursuing their selfinterests is a more efficient, and more effective oversight system than a governmental, regulatory system. ${ }^{822}$ Sowell, also writes at length about the tragedy of the commons, and argues that common ownership of resources inevitably results in the overexploitation of the resource. ${ }^{823}$ Sowell's solution to the matter is to apply a property rights regime to commonly held property so that individual owners will have an incentive to use the resource as to guarantee its future sustainability and by extension its future profitability. ${ }^{824}$ Sowell's argument, ultimately hinges on the idea that the property system provides incentives for property owners to keep their property from being overexploited, falling into a state of disrepair. ${ }^{825}$ The incentive, of course, is an owner's desire to continue to enjoy the profits, rents, or the extraction of valuable resources from the property itself.

While some of Sowell's ideas about property and resource exploitation may not square with traditional notions of tribal land use and management, his point about incentives and land alienability are crucial to our libertarian framework for Indian rights. The first point to glean from Sowell's remarks is that the Indian land tenure system is in radical need of reform if tribes

\footnotetext{
${ }^{818} I d$. at 423.

${ }^{819} \mathrm{Id}$.

${ }^{820} \mathrm{Id}$.

${ }^{821} \mathrm{Id}$. at 424 .

${ }^{822} \mathrm{Id}$.

${ }^{823} \mathrm{Id}$.

${ }^{824} \mathrm{Id}$.

${ }^{825} \mathrm{Id}$. at 426.
} 
and tribal peoples are to enjoy the profit-based incentives that property ownership provides. Of course, the property rights history in Indian Country is "exceptionally complicated" and there are a variety of Indian land tenure whether on the reservation or off. ${ }^{826}$ Whether the tenure is "tribal trust land, individual trust land, tribal fee simple land, individual member fee simple land, nonIndian fee simple land, and federal, state and/or county land," ${ }^{827}$ land transactions are particularly complicated by Indian trust status, which all but renders trust parcels worthless as collateral use for securing capital. ${ }^{828}$ The result is that Indians and Indian tribes can possess tremendous amounts of acreage but find themselves locked out of securitized lending, "one of the basic drives of economic and community development." ${ }^{229}$

The status of Indian land, the problem of allotment fractionation, and the myriad of administrative policies and management directives accompanying federal trust status renders much of Sowell's praises of property ownership inapplicable to Indian Country. This does not mean that Sowell is wrong, or that his contribution to a libertarian framework for Indian rights is to be discounted. His inference that Indian land resources should be able to be put to productive use and made alienable is still prescient, despite the pitfalls of the current system. Perhaps the most important aspect of Sowell's theory as it relates to the status of Indian lands, is his caution against burdensome regulatory hurdles in land management and development. Sowell writes at length about the self-monitoring apparatus created by the mere ownership of property, citing a number of examples from private sector businesses. ${ }^{830}$ His ultimate conclusion is that this system of profit-driven incentives is a more effective monitoring system than formal regulatory

\footnotetext{
${ }^{826}$ Harvard Project on American Indian Economic Development, supra n.10 at 98.

${ }^{827}$ Id. at 98.

${ }^{828}$ Id. at 102 .

${ }^{829} \mathrm{Id}$.

${ }^{830}$ Sowell, supra n.547 at 423.
} 
regimes. ${ }^{831}$ Indian lands provide an almost perfect foil for Sowell's monitoring system. Indian lands have always been heavily regulated, even to the point of dispossession. ${ }^{832}$ The result is a chaotic system of Indian land tenure in existence to day. If there is a principle to be gleaned for a libertarian framework for Indian rights from Sowell's reflection on property rights, and the state of Indian lands, it is that meaningful property rights must include the right of Indian property owners to alienate and manage their lands.

\section{Reviving the Reservation: De Soto on Dead Capital}

Hernando De Soto's study of the "informal economy" provides many lessons and possible solutions to the Indian property rights dilemma of the preceding section. According to De Soto, dead capital exists when there is no system for converting physical assets into capital through the process of securitized lending. ${ }^{833}$ The problem he identifies in many developing nations is absence of a formal property system - rendering the benefits of the price system, and the communicative effects of pricing all but muted. ${ }^{834}$ His solution is to formalize property systems through implementation of processes for recording title. ${ }^{835}$ Only when property rights are formalized can property owners enjoy a property's potential value ${ }^{836}$ its integration into property systems, thereby providing for more efficient property transactions, ${ }^{837}$ better accountability in business dealings, ${ }^{838}$ the fungibility of assets, ${ }^{839}$ and the actual protection of transactions through

\footnotetext{
${ }^{831} I$ d.

${ }^{832}$ Harvard Project on American Indian Economic Development, supra n.10 at 96.

${ }^{833}$ De Soto, supra n.561 at 40.

${ }^{834} \mathrm{Id}$. at 47.

${ }^{835} \mathrm{Id}$. at $46-47$.

${ }^{836} \mathrm{Id}$. at 50 .

${ }^{837} \mathrm{Id}$. at 52.

${ }^{838} \mathrm{Id}$.

${ }^{839} \mathrm{Id}$.
} 
formal record keeping. ${ }^{840}$ To state matters simply, formal property systems provide a number of checks that allow for property to be meaningfully owned, and potentially used as capital. ${ }^{841}$

Given the state of Indian lands described above, De Soto's observations about dead capital are very much a reality in Indian Country though not necessarily for the reasons that De Soto describes. In the United States, the system of private property is alive and well with formal processes for assigning ownership and title. But the problem of dead capital in Indian Country is intricately tied to the restrictions of the trust system that make it incredibly difficult to alienate and develop Indian lands. ${ }^{842}$ The result is that dead capital exists in Indian Country, but not for want of a formal property system. Dead capital exists due to the crippling regulations imposed by the Federal Government, meaning that De Soto's observations are correct, but for the wrong reason. The implications for De Soto's work for a libertarian framework for Indian rights is ultimately a variation on the work of Thomas Sowell. Indian lands trust lands are constrained from capitalization because of an antiquated federal trust system that hampers rather than promotes development.

The result of the federal trust system is a fairly stark inequality, American Indian trust lands on the outside of the American property rights system looking in. Far from enjoying meaningful ownership, the complicated Indian land tenure system has the effect of merely providing Indian landowners with a right of occupancy, leaving them unable to enjoy the full benefits of capitalization and securitized lending despite the existence of a formal property system that serves almost everyone else. Similarly, Indian lands may have economic potential, or

\footnotetext{
${ }^{840} I d$. at 61.

${ }^{841} \mathrm{Id}$. at 62.

${ }^{842}$ Harvard Project on American Indian Economic Development, supra n.10 at 101.
} 
"potential value" but in large part it remains only potential because of alienability and land use restrictions. $^{843}$

De Soto's also declares accountability as a benefit of formal property systems. But again, the experience of Indian Country demonstrates his inference to be true for the wrong reason. In the lengthy Cobell litigation, ${ }^{844}$ a class action suit aimed at righting mismanaged Indian trust accounts, the government was forced to admit that not only did not know how many Individual Indian Money trust accounts it was tasked with managing, but that it also did not know the proper balances of the accounts, and that it did not have the records by which to ascertain their value ${ }^{845}$ De Soto's point is that accountability is a by-product of the formal property system because it helps to make individuals accountable in their business dealings ${ }^{846}$ But given the experience of American Indians, this seems to be truer in the private sector, than when the Federal Government severely restricts the alienability, development, and profits of lands - and then bungles the accounting process of the assets they are tasked with managing. On this score, De Soto's implication for a libertarian framework for Indian rights is that accountably through formal property systems can be realized only when landowners have meaningful ownership rights and the ability to make choices over transactions affecting their property. Absent meaningful property rights, the assets of Indian lands cannot be made. ${ }^{847}$

\section{Unleashing Indian Creative Capacity}

So far in this application of economics to the libertarian framework for Indian rights, the work of Adam Smith has underscored the importance of developing a service-based economy on the reservation. Milton Friedman's work highlights the correlation between economic and

\footnotetext{
${ }^{843}$ De Soto, supra n.433 at 50 .

${ }^{844}$ Cobell v. Salazar, 573 F.3d 808 (9th Cir. 2009).

${ }^{845}$ Cobell v. Norton, 240 F.3d 1081, 1089-1090 (D.C. Cir. 2001).

${ }^{846}$ De Soto, supra n. 433 at 54.

${ }^{847}$ Id.
} 
political freedom and the need to cultivate a climate of business opportunity in Indian Country. From Thomas Sowell, the libertarian framework for Indian rights gains a significant perspective on the need to have meaningful property rights that is ultimately supported by Hernando De Soto's excoriation of dead capital and the effects of the Indian land tenure system on the reservation. But while markets, freedom, property rights and capital are all important components of our libertarian framework for Indian rights, these elements would all be for naught apart from the creative capacity of Indian people to pursue their rational, self-interest.

The theme of Ayn Rand's work in the novel Atlas Shrugged is that the pursuit of individual self-interest is the normative ethic driving the engine of all economic productivity. ${ }^{848}$ This objectivist notion amounts to the simple concept that governments tend to stifle innovation through schemes of redistribution, while taking for granted the talents of innovators that have played significant roles in the world's social progress. ${ }^{849}$ As society begins it collapse in the novel, government and its nationalized businesses are helpless to replicate the innovation of the market, and the world's great entrepreneurs who went on strike. ${ }^{850}$ The point of Rand's rebuke in the novel is to challenge nationalist sentiments esteeming governmental systems over the dignity and productive capacity of the individuals. The solution to this sense of imbalance in the novel is the maximization of human creative capacity. ${ }^{851}$ Rand assumes that all sentient beings possess a mind, and the ability to reason, and by extension the choice to be productive - regardless of the manner in which they choose to deploy their talents. ${ }^{852}$ Ethically, this choice to be productive, or

\footnotetext{
${ }^{848}$ Rand, supra n.587 at 1076.

${ }^{849}$ Id. at 925.

${ }^{850} \mathrm{Id}$. at 924

${ }^{851} \mathrm{Id}$. at 930

${ }^{852} \mathrm{Id}$. at 930 .
} 
to work is Rand's highest ideal - it is the lone wisp of "consciousness" that allows individuals the opportunity to transform the world through purpose..$^{853}$

Regarding the role of government, Rand argues that the selection of one's vocation is an essentially humanizing function, one reserved for individuals alone ${ }^{854}$ Under this mindset, Governments have relatively little authority to assign occupations or dictate the terms of productivity, because the fundamental purpose of one's humanity is to maximize individual potential. Accordingly, Rand argues extensively for free markets, allowing individuals to compete on their own merit, without the lurking specter of governmental coercion, whether in the form of tariffs on goods or taxes on income. ${ }^{855}$

While aspects of Rand's ideology, and objectivist philosophy will not be familiar to some tribal values placing the community ahead of individual members of the community, the principle contribution she makes to a libertarian framework for Indian rights is the idea that human creative ability is backbone of a healthy economy. In Atlas Shrugged, Rand demonstrates in a powerful way that people do the productive work of hoisting the worlds on their shoulders, and that this basic creative function is not one that can be commanded and controlled by governmental fiat. For Indian Country, this notion comports well with the goals of measured separatism and tribal self-determination. Indian people and the tribal nations they comprise are uniquely situated to understand the challenges facing their communities, and they are in the best position to know how to address these respective issues. At a minimum, Rand's belief in the productive and creative capacity of individuals requires a rethinking of the, at best, paternalistic government-to-government relationship between the Federal Government and Indian nations.

\footnotetext{
${ }^{853} \mathrm{Id}$. at 933 .

${ }^{854} \mathrm{Id}$.

${ }^{855}$ Id. at $936-937$.
} 
Rand's musings about the evils of nationalization also raise interesting questions for a libertarian framework for Indian rights. ${ }^{856}$ The Indian trust system itself is in many ways a nationalization of Indian lands. Depending upon the land tenure involved, Indian landowners with their lands in trust are barred from the full use and enjoyment of their lands. Taking lands out of trust, for many of these individuals is simply not an option since they may lack the resources to pay property taxes on their land should it be removed from trust. In this way, the trust system is self-perpetuating. Indian lands are left in trust, because a stifling tax system prevents relative business novices from putting it to productive use outside of trust. Thus, Rand's warnings about nationalization are particularly relevant. Private lands that are placed under governmental, regulatory oversight tend to stay there. Perpetuating dead capital, and creating disincentives for landowners to put the lands to productive use. This suggests that a libertarian framework for Indians rights must restructure the trust relationship with the Federal government in such a way that Indian lands can be made to work for American Indians, promoting their economic welfare, and raising their quality of life.

Similarly, Rand's alternative to the social welfare state also brings a challenge to extant Federal efforts to spur economic development in Indian Country. At the heart of her message is the notion that individuals much choose to be productive individuals, seeking out some type of work or vocation that will enable individuals to maximize their potential ${ }^{857}$ This idea is crucial to a libertarian framework for Indian rights, particularly when one considers that American Indians have consistently struggled against high levels of unemployment, and underemployment despite modest gains made during the heyday of Indian gaming in the $1990 \mathrm{~s} .{ }^{858}$ Any effort to spur economic development on the reservation must be accompanied by an intent to promote

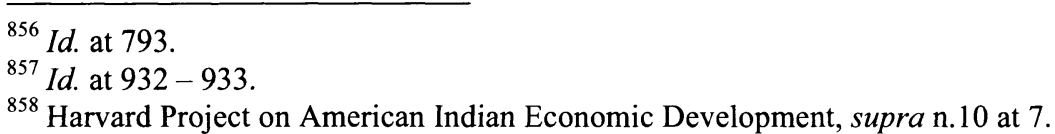


vocational opportunities among low income members of Indian communities - particularly among younger generations of American Indians who will one day ascend to positions of leadership within their respective tribes. As Rand implies, providing opportunities for individuals to maximize their creative capacity through meaningful work is far different matter than obliging policies aimed at enhancing a social welfare state on the reservation. To be clear, social services are necessary and ubiquitous as a hallmark of modern, democratic governments. But a concerted effort to raise employment levels, and the development of a service-based economy on the reservation is means by which Indian Country can eventually end the need for ward status under the Federal Government.

Finally, it is worth mentioning that there will surely be many objections to incorporating elements of Rand's objectivist philosophy in my libertarian framework for Indian rights. Her views of individualism, and the pursuit of self-interest may seem anathema to Indigenous communities that have lengthy histories of communal decision-making, and ceremonial traditions that involve selflessly sharing one's bounty with the community. Despite these objections, it is important to recall the positions of Nozick and Hayek who deftly argue that libertarianism is by definition incremental. The goal is not to impose a one-size fits all model of governance on Indian people. The Federal Government has already attempted this with mixed results. ${ }^{859}$ Rather, the point encompassed by Rand's philosophy for our libertarian framework for Indian rights is that Indian peoples are a capable group of individuals who deserve the opportunity to manage their own affairs - who are and of a right ought to be free to pursue whatever interests they have - whether the interests be in common or unique to the individual. This framework seeks to implement this basic principle in all three areas of its scope.

\footnotetext{
${ }^{859}$ See The Indian Reorganization Act, 25 U.S.C. $\S \S 461$ - 479 (1934).
} 


\section{CHAPTER 6}

\section{IMPLEMENTING THE FRAMEWORK}

The preceding chapter outlines a new framework for Indian rights based upon the principles of libertarian philosophy. This chapter explores the next step in the analysis, which is to evaluate some of the ways that the framework can be implemented at the Federal policy level. I acknowledge that there may be some objection to analyzing the framework at the Federal level. Applications of the model could readily be analyzed at the tribal, state or local level given that governmental abuses of power, liberty and free association occur at nearly every level of government. Still, implementing the framework at the Federal policy level is appropriate given the realities of the current system, which assumes that Congress has plenary power over Indian affairs. This reality is, of course, quite normatively objectionable under the libertarian framework constructed. But libertarian incrementalism, nonetheless, allows for the opportunity to effect policy changes within extant power structures in hopes of creating a meaningful framework of rights and change over time. This chapter opens with a summary of the libertarian framework for Indian rights and then proceeds to examine specific policy suggestions that would begin the process of implementing the new model. 


\section{A. Summarizing of the Libertarian framework for Indian rights}

The libertarian framework for Indian rights envisions a new model for Indian rights consisting of three elements that can be implemented incrementally over time through pragmatic change: 1) limiting the role of the Federal Government in Indian affairs, 2) emphasizing the importance of freedom in securing Indian rights, and 3) underscoring the importance of markets in the realization of Indian of rights.

Regarding the role of the Federal Government in Indian affairs, the libertarian framework for Indian rights assumes that American Indians are entitled to the same rights under the law as all other peoples and that governments exist to protect these rights from violation. Given the libertarian right of free association, tribal governments and tribal institutions are protected under a libertarian framework as the rights of individuals to freely associate and form communal organizations of government. Tribal sovereignty and tribal self-governance are successive rights based upon the will of likeminded individuals to freely associate and organize governments. This indicates that a libertarian framework for Indian rights is one that embraces the ideal of measured separatism for Indian tribes by affording them the opportunity to govern their reservations according to their customs and traditions without the threat of interference from the Federal Government. This stands in stark contrast to the trust doctrine and the modern principles of Federal Indian that place the very existence of Indian tribes at the caprice and munificence of the Federal Government.

The normative ideal buttressing this view of the government-to-government relationship between Indian tribes and the United States is the simple libertarian ethic that law cannot be used to destroy the person, liberty or property of individuals and groups alike. ${ }^{860}$ This norm pervades much of libertarian thought and limits the role of government to that of a "negative" function,

\footnotetext{
${ }^{860}$ Bastiat, supra n.379 at 2.
} 
meaning that governments exist only to prevent injuries to rights from occurring ${ }^{861}$ While much of the extant legal framework of Indian rights uses law as a tool for the manipulation and control of Indian peoples, the libertarian framework for Indian rights envisions law as being merely the protector of the rights Indian people and the means by which violations of rights are corrected. Measured separatism between Federal and tribal governments is viewed as a given within the libertarian framework for Indian rights due to the libertarian principle of free association.

Like the role of limited government, the widespread promotion of freedom is another indispensible element of a libertarian framework for Indian rights. This principle assumes that American Indians have a right to be free from state coercion in order to allow individuals the opportunity to chart their own paths in life. This suggests that the role of the Federal Government should be constrained vis-à-vis tribal governments in order to allow individual Indians and their tribal governments to have the opportunity to shape their courses of action without the threat of a coercive state manipulating the Indians' will to exercise tribal sovereignty. Given this libertarian view of freedom, it is not surprising that the libertarian framework for Indian rights forthrightly rejects the institution of plenary power, dismissing it, in the words of Locke, as "despotical power" that is inconsistent with modern notions of civil government. ${ }^{862}$ As a result of this fundamental mistrust of plenary power, the libertarian framework for Indian rights is similarly skeptical of the right to govern and the right to title merely by virtue of a nation's conquest. Such power is inherently a myth under a libertarian framework for Indian rights due to the myriad of executive agencies carrying out the many laws affecting Indian affairs, and the active role of the Judiciary in reinforcing the legal regime of plenary power. The libertarian framework for Indian rights suggests using legislative institutions to implement an incremental agenda of reform

${ }^{861} I d$. at 25.

${ }^{862}$ Locke, supra n.348 at $93-94$. 
through checks and balances on the power of the Federal Government itself. Again, such measures need not seek to upend the entire Federal Indian law structure. Libertarian incrementalism embraces the notion of seeking piecemeal change overtime as a means of achieving systemic reform.

Finally, the role of markets in constructing a libertarian framework for Indian rights is actually a corollary requisite to the realization of meaningful freedom in Indian Country. Under the libertarian framework for Indian rights, it is crucial that Indian Country begin the long task of developing a service-based economy on the reservation as a means of generating capital for American Indians. Absent economic opportunity, tribal nations will continue to lag behind the dominant culture of the United States, relegated to being one of the poorest peoples in the land..$^{863}$

But in order to develop a service economy in Indian Country, the libertarian framework for Indian rights underscores the importance of developing business friendly climates in areas where a service-based economy has never existed. The framework implies that tribal nations must work to attract investment capital to the reservation and develop entrepreneurs on the reservation through institutional reform (where necessary) that provides for modern zoning ordinances, infrastructure, better leasing systems, and long-term and short-term land use planning. ${ }^{864}$ Finally, under the libertarian framework for Indian rights, overhauling Indian Country's business climate also requires the implementation of tax schemes that take as little as possible from citizens and businesses. Libertarian philosophy is skeptical of tax schemes that go beyond funding the basic governmental services necessary to protect rights, because of the very real threat that stifling tax policies can prematurely end the small business efforts of

\footnotetext{
${ }^{863}$ Harvard Project on American Indian Economic Development, supra n.10 at 7. ${ }^{864}$ Id. at 129.
} 
entrepreneurs - particularly in developing economics such as the nascent service-based economy of the reservation.

Given this basic economic outline under a libertarian framework for Indian rights, the economic choices of tribal governments must be freely maximized without the lingering specter of the Federal Government unsettling expectations. ${ }^{865}$ In other words, actual freedom in Indian Country can only be realized through a concomitant economic freedom. Absent the authority to make meaningful economic decisions, Indians and Indian tribes simply cannot fully realize the ideals of freedom outlined above. Accordingly, a Libertarian framework for Indian rights assumes that Indians have the opportunity to pursue their self-interest in the market place whether those interests are motivated by a personal desire to turn a profit, or by a desire to advance the values of Indian communities. The development of markets in Indian Country also portends a change in the quality of life in rural, reservation communities under the libertarian framework for Indian rights. Rather than forcing community members to travel off-reservation to obtain basic goods and services, the development of markets in Indian Country offers those individuals living within the community the opportunity to provide goods and services to the community itself, while making the distribution of products more efficient, and more responsive to the needs of Indian Country's denizens.

In order to develop this market, however, the libertarian framework for Indian rights acknowledges the need for significant reforms in the property rights regime currently imposed on Indian Country and Indian property owners. The framework contemplates the need to implement polices at the Federal level that will allow Indian lands to be more easily put to productive use including alienability - in order to provide Indians and Indian tribes with the opportunity to leverage their most bountiful assets. Some may object to my use of the term productive use, in

\footnotetext{
${ }^{865}$ Friedman, supra n.492 at 2.
} 
fact one scholar has described it as the language of assimilation. But this reflects a misunderstanding of the term as I have applied it in the new model. Policies giving Indian tribes and landowners more control over their land assets does not assume that Indians and Indian tribes will be forced to alienate their lands, or even remove them from Federal trust status. Rather the framework suggests that the Federal Government should work to remove barriers to choice for those Indians and Indian tribes wishing to leverage their land assets. Foremost among these barriers to capital is the Indian trust land system, which leaves American Indian trust lands locked within a complex system of land tenure that renders Indian lands inalienable apart from obtaining the formal blessing of the Federal Government. ${ }^{866}$

Finally, in order to develop a healthy economy in Indian Country, the libertarian framework for Indian rights assumes that Indian entrepreneurs and community members should have ample opportunity to participate in the tribal economy. It assumes that the goals of measured tribal separatism and tribal self-determination are well-served by having a base of tribal workers that can utilize their creative capacities to do the productive work of building the economy in Indian Country. This principle embraces the need for a fundamental rethinking of the government-to-government relationship between tribes and the Federal Government as economic development policies relate to Indian Country. Like the musings on land tenure, Indian creative ability must be unleashed in such a way that individual landowners, and Indian tribes can use their land assets in a productive way for the benefit of both Indian landowners and tribal members. Naturally, this implies that any policy efforts at the Federal level to promote economic development must be accompanied by promoting vocational opportunities among members of

\footnotetext{
${ }^{866}$ See The Non-Intercourse Act of 1799, March 3, 1799, Pub. L. No. 5-46, § 12, 1 Stat. 743, 746 (2012), and The Non-Intercourse Act of 1802, March 30, 1802, Pub. L. No. 7-13, § 12, 2 Stat. 139, $143(2012)$ as a barriers of tribal alienation of lands.
} 
Indian communities without access to such forms of higher education. The libertarian framework for Indian rights and its emphasis of individual creative capacity also acknowledges the need to maintain basic social services in Indian Country in order to develop a self-sustaining economy and in hopes of the eventual elimination of the need for "ward status" under the Federal Government.

\section{B. Re-envisioning the Government-to-Government Relationship}

Given the framework of Indian rights above and the progression of this work's analysis, the exercise of implementing the libertarian framework for Indian rights logically begins by exploring ways to re-envision the government-to-government relationship between Indian tribes and the United States. The libertarian ideal of limited government in Indian affairs can be applied in two practical ways: 1) through increased tribal/Federal consultation, and 2) through promoting measures that advance tribal self-determination in the expansion of tribal criminal jurisdiction.

\section{Tribal Consultation as the New Treaty Making}

Formal treaty making with Indian tribes ended in $1871 .{ }^{867}$ But the trend toward increased tribal/federal consultation began with the successful case study involving the Northern Cheyenne and Lakota Sioux tribes, more than a decade ago, when they became embroiled in the famous land management dispute over Devil's Tower National Monument in 1995. The dispute marked one of the first tests of tribal consultation, pitting the religious interests of American Indian tribes who considered the site to be sacred against the romantic history of technical rock climbing that helped to make the site famous. ${ }^{868}$ What made this otherwise perfunctory administrative matter unique was the way in which the Federal agency in charge (the National Parks Service) actively reached out to American Indians and climbing advocates alike in hopes of reaching a consensus

\footnotetext{
${ }^{867} 25$ U.S.C. $\S 71$ (2012).

${ }^{868}$ Lloyd Burton and David Ruppert, Bear's Lodge or Devils Tower: Inter-Cultural Relations, Legal Pluralism, and the Management of Sacred Sites on Public Lands, 8 Cornell J.L. \& Pub. Pol'y 201, 214 (1999).
} 
decision as to the administration of the park. ${ }^{869}$ The de facto result of this consultation was the purposeful negotiation of an agreement with Indian tribes that implemented a voluntary climbing ban during the month in which tribal ceremonies are conducted at the site. ${ }^{870}$

While the Devil's Tower case study bespeaks a mostly positive outcome in the tribal consultation processf, there are many instances of tribal consultation that do not reach the same end, and outcomes from the consultation process are far from guaranteed. ${ }^{871}$ Still, the libertarian framework for Indian rights supports the policy of increased tribal/federal consultation in that the concept is premised upon a gradual incorporation of American Indian perspectives into the decision-making processes affecting American Indians. The libertarian framework for Indian rights affirms measures to allow individuals to freely associate in the organization of governments, and to have those governmental bodies respected by other sovereigns. The tribal/federal consultation process is an example of free association and the respect of sovereignty in that it allows American Indian views and interests to be incorporated into the plans of federal agencies, thereby affording tribal nations actual recognition of their sovereignty by the Federal Government. ${ }^{872}$ This view of tribal/federal consultation is also consistent with the framework's respect for the ability of American Indians to freely defend their rights under the law. And it is also consistent with the libertarian ethic that law cannot be used to destroy personhood, liberty, or property. In this regard, consultation seeks to protect the rights of American Indians from potential abuses by the Federal Government- in the Devil's Tower

\footnotetext{
${ }^{869} \mathrm{Id}$. at 213.

${ }^{870}$ Burton and Ruppert, supra $\mathrm{n} .868$ at $216-217$.

${ }^{871}$ E.g., the experience of the Navajo and Hopi tribes in the San Francisco Peaks litigation. See University of Arizona, San Francisco Peaks Sacred Site Litigation, http://www.arizonanativenet.com/law/index.cfm?subj=sacred\&sect=law (accessed Mar. 18 2012).

${ }^{872}$ Burton and Ruppert, supra $\mathrm{n} .868$ at 240.
} 
example, consultation aided in the protection of American Indian religious freedoms, even if the ultimate land management agreement was pragmatic. ${ }^{873}$

Similarly, the tribal/federal consultation is also notable for its potentially broad application. The Devil's Tower case study involved questions about the viability of American Indian religions, but given rising energy prices ${ }^{874}$ and recent efforts to develop an alternative energy base in the United States, tribal/federal consultation has also become a major issue in the development of renewable energy projects across Indian Country ${ }^{875}$ Since many tribes own vast amounts of acreage in areas of the U.S. that are optimal for solar and wind energy projects, the Federal Government and its agencies now have additional incentives to engage tribes through the consultation process. The consequences for neglecting tribal interests include meaningful risks to development ranging from temporary and indefinite delay, to the ever-lurking specter of litigation. ${ }^{876}$ Naturally, this policy application is consistent with the libertarian framework for Indian rights in that it places tribal nations at the helm of negotiations with a separate sovereign, and contemplates a degree of measured separatism between Indian tribes and the U.S. Government as the two seek to address the future of America's energy resources.

\section{Measured Separatism and Meaningful Self-Determination}

While developing and strengthening the federal policy of tribal consultation is a desirable, incremental application of the libertarian framework for Indian rights, the ideal of limited government can neither be achieved through tribal consultation alone, nor will such a limited application secure Indian tribes the degree of measured separatism they desire in the selfdetermination of their own affairs. In order for the influence of the Federal Government to be

\footnotetext{
${ }^{873}$ Bastiat, supra n. 379 at 2.

${ }^{874}$ See Zunaria Zaki, Highest Gas Price Recorded in March, http://abcnews.go.com/blogs/business/2012/03/highestgas-price-recorded-for-march/ (Mar. 19, 2012).

${ }_{875}$ David S. May, Consulting With Tribes for Off-Reservation Projects, 25-SUM Nat. Resources \& Env't 54 (2010).

${ }^{876} \mathrm{Id}$. at 56.
} 
meaningfully limited and allow for a degree of measured separatism for Indian tribes, a modicum of governmental parity must be established through the development of actual tribal jurisdictional authority over the reservation boundaries. Taking the example of criminal jurisdiction alone, tribal, state, and federal governments remain perpetually at odds over the exact scope of authority each government wields over the prosecution of criminals in Indian Country. Add to this federally imposed limits on tribal criminal jurisdiction (both legislative and judicial), and the question "who's in charge" has true relevance in Indian Country with often fatal consequences. ${ }^{877}$

One result of the federally imposed jurisdictional limitations on tribes has been a surge in crime in Indian Country that includes increased rates of sexual assaults, rape,${ }^{878}$ and violent crimes on the reservation - some of which are upwards of twenty times the national average, depending upon the reservation. ${ }^{879}$ Tribal governments decry the jurisdictional maze that undermines their authority to exercise criminal jurisdiction over the reservation. But calling the matter a maze is really a generous use of the word 'maze.' Mercer University Law School's Suzianne D. Painter-Thorne has described the matter as a "jurisdictional knot that is more likely to thwart justice than to serve it. ${ }^{" 880}$ As noted above, the lack of tribal criminal jurisdiction stems from patchwork of federal statutes, agency regulations, executive orders and caselaw that combine "to create confusing overlaps of authority in some instances and jurisdictional gaps in

\footnotetext{
${ }^{877}$ For a discussion of the federally imposed limits on tribal criminal jurisdiction, See Gideon M. Hart, A Crisis in Indian Country: An Analysis of the Tribal Law and Order Act of 2010, 23 Regent U. L. Rev. 139 (2010).

${ }^{878}$ See also Sarah Deer, Sovereignty of the Soul: Exploring the Intersection of Rape Law Reform and Federal Indian Law, 38 Suffolk U. L. Rev. 455 (2005).

${ }^{879}$ Suzianne D. Painter-Thorne, Tangled Up In Knots: How Continued Federal Jurisdiction Over Sexual Predators on Indian Reservations Hobbles Effective Law Enforcement to the Detriment of Indian Women, 41 N.M. L. Rev. 239,243 (2011).

${ }^{880}$ Id. at 246 .
} 
others." ${ }^{881}$ The result is that tribes have been hamstrung in their ability to police the reservation for want of federal or state law enforcement that is only notable for its absence. ${ }^{882}$

Despite the well-documented problem of crime in Indian Country, scholars are split on ways to address this increasingly urgent issue. One solution tested by Congress in the State of Kansas has resulted in an extreme non-prosecution of crimes in Indian Country once general criminal jurisdiction over Indian Country was conferred upon the State of Kansas. ${ }^{883}$ Tribes are already categorically barred from the prosecution of non-Indians, ${ }^{884}$ meaning that the Kansas experiment has resulted in the double prosecution of Indian defendants in both tribal and state courts. ${ }^{885}$ This creates important questions about due process in sentencing by separate sovereigns - particularly as those issues relate to law enforcement, judicial resources, and the disproportionate effect that the law has on Indian defendants. ${ }^{886}$

The libertarian framework for Indian rights assumes that American Indians are entitled to the same rights under the law as all other peoples. Actions by the Federal government to divest tribal jurisdiction violate the basic libertarian ideal of free association, and the right of individuals to organize the very governments making decisions on their behalf. Far from increasing federal involvement in Indian affairs, the libertarian framework for Indian rights envisions limiting federal involvement in criminal jurisdiction over the reservation for want of strengthening tribal law enforcement capabilities, and strengthening tribal judiciaries.

Enforcement of laws on the reservation based on race, which is the current state of things under

\footnotetext{
${ }^{881}$ Id. at 247.

${ }^{882} \mathrm{Id}$.

${ }^{883}$ John J. Francis; Stacy L. Leeds; Aliza Organick; Jelani Jefferson Exum, Reassessing Concurrent Tribal-StateFederal Criminal Jurisdiction in Kansas, 59 U. Kan. L. Rev. 949, 967 (2011).

${ }^{884}$ See Oliphant $v$. Suquamish Indian Tribe, 435 U.S. 191 (1978).

${ }^{885}$ Francis, Leeds, Organick \& Exum, supra n.883 at 983.

${ }^{886}$ Id. at 984 .
} 
the Supreme Court's ruling in Oliphant, ${ }^{887}$ would be a non sequitur under the libertarian framework for Indian rights given its assumption that all individuals are entitled to the same rights under the law. Race-based enforcement of law, whether tribal, state, or federal simply has no place within a libertarian framework of rights.

The double prosecution of American Indians resulting from the Kansas $\mathrm{Act}^{888}$ also violates the libertarian framework for Indian rights, and the ethic for limited government, which holds that law cannot be used as tool for manipulation and control (viz., coercion) because such uses of law breach the government's obligation to protect the life, liberty and property of Individuals and groups. While it is true that violations of the rights of others require punitive consequences, even under the libertarian framework for Indian rights, the framework itself does not contemplate punishments that go beyond what is necessary to correct the violation of rights. ${ }^{89}$ The Kansas Act not only metes out double punishment singularly to American Indian defendants, but it also has the effect of placing the State as an overlord of the tribes, undermining the authority of tribal governments to govern their reservations.

The most effective use of the libertarian framework for Indian rights in accomplishing the goal of measured separatism is in rooting arguments for tribal jurisdiction in the principles of limited government at both the legislative and administrative level. For tribal advocates seeking change, endorsing and advancing pragmatic policy changes that maximize tribal jurisdiction over the reservation will find powerful arguments in the framework based upon the libertarian ethic that law should not be used as a tool for control in the destruction of the person, liberty or property, and in the libertarian ideal that governments exist to prevent injuries from occurring. As a result, federal policy changes with regard to tribal criminal jurisdiction should be

\footnotetext{
${ }^{887}$ See Oliphant v. Suquamish Indian Tribe, 435 U.S. 191, 212 (1978).

88818 U.S.C. $\S 3243$ (2012).

${ }^{889}$ Nozick supra n.347 at 118.
} 
considered, not because the trust doctrine and principles of Federal Indian law say as much (in fact, the Oliphant opinion all but indicates the opposite). Rather, changes in tribal criminal jurisdiction should be considered because free people deserve a government that can effectively protect their security interests. Given the abysmal results of federal and state efforts to police Indian Country, tribal governments deserve the opportunity to assume jurisdiction because the principles of limited government demand it.

\section{Meaningful Freedom in Indian Country}

Having explored opportunities to promote the principles of limited government in Indian Country, the next exercise in the implementation of the libertarian framework for Indian rights involves analyzing opportunities for the realization of meaningful freedom in Indian Country. While there are many areas of Indian law to apply the concept, what follows is a macro-level, two-fold application of the libertarian framework for Indian rights, and its maximization of freedom in Indian affairs: 1) through the limitation of coercion in Indian Country, and 2) through re-examining the doctrine of Congressional plenary power over Indian affairs.

\section{Limiting Federal Coercion in Indian Country}

The libertarian framework for Indian rights assumes that all individuals have the right to be free from state coercion. The relationship between liberty and coercion is an inverse one, which, borrowing from Hayek, defines liberty as the social condition of reducing the coercion of some individuals by others as much as possible. ${ }^{890}$ Such a view, of course, reinforces the ideals of the preceding section on limited government, but it also suggests that any meddling by the Federal Government in the affairs of Indian tribes is an undesirable threat to liberty. The most

${ }^{890}$ Hayek, supra n.397 at 11. 
obvious instrument of governmentality at work as it relates to Indian Country is the trust doctrine first articulated by Justice Marshall in Cherokee Nation v. Georgia. ${ }^{891}$

The original conceptualization of the trust doctrine in Federal Indian law had two effects on the emerging tribal/federal relationship: First it indicated the primacy of federal authority over Indian affairs. ${ }^{892}$ Second, it indicated a "concomitant limit" on the power of states over Indian affairs in the newly emerging republican framework. ${ }^{893}$ As a result, the U.S. Government assumed a fundamental "imperative to protect Indian tribes against the encroachments of states and other citizens," that has come to be known as the trust doctrine. ${ }^{894}$ While the doctrine of trust may seem to be a fairly specific defense of tribal interest, when combined with the doctrine Congressional plenary power, the trust doctrine has been used to legislate on behalf of American Indians in a number of policy areas - ranging from health care, to education, to land management, to cultural patrimony and quite nearly everything in between ${ }^{895}$ Given the pervasiveness of federal regulation and oversight assumed under the trust doctrine in Indian affairs, the resultant question is whether the trust relationship between the Federal Government and Indian tribes is still a shield for protecting tribal interests, or merely an excuse for increased coercion by the state?

At the root of the dilemma is the incongruity between Congressional plenary power over Indian affairs and the Federal Government's trust obligation to Indian tribes. Lincoln Davies of the University of Utah eloquently summarized the matter in a 2009 article as follows:

\footnotetext{
${ }^{891}$ Cherokee Nation v. Georgia, 30 U.S. 1, 17 (1831).

${ }^{892}$ Ray Torgerson, Sword Wielding and Shield Bearing: An Idealistic Assessment of the Federal Trust Doctrine in American Indian Law, 2 Tex. F. on C.L. \& C.R. 165, 172 (1996). Note: At the time of his article's publication Mr. Torgerson was a law student at The University of Texas School of Law. He is now a partner at Porter, Hedges law firm in Houston, TX.

${ }^{893} I$ d.

${ }^{894}$ Kristen A. Carpenter, Sonia K. Katyal, Angela R. Riley, In Defense of Property, 118 Yale L.J. 1022, 1028 (2009).

${ }^{895}$ Id. at $1058-1059$.
} 
Even a brief step back reveals that tribal sovereignty and the federal trust are, on their face, irreconcilable. On the one hand, sovereignty is about self-governance and selfdetermination; it is about tribal power. The trust, on the other hand, is about a federal duty to protect Indians; it is about the submission of tribal power to a higher authority. ${ }^{896}$

The problem so simply framed by Davies, whether the trust doctrine is about protecting Indians or subordinating them to the Federal Government, is one of the vanguard problems now facing Federal Indian law scholars. The question as considered under the libertarian framework of Indians rights tends to support a view of the trust doctrine as an impermissible act of coercion by the state.

Given the manifold examples of Federal legislation that has constrained tribal sovereignty, ${ }^{897}$ the libertarian framework for Indian rights is fundamentally at odds with any efforts by the arbitrary will of the Federal Government to control the circumstances of tribes such that Indians are obliged to follow the plans of the state rather than the coherent plans of the tribes themselves. ${ }^{898}$ The very definition of coercion includes the paramount control of an environment such that a person must act according to the ends of another in order to avoid a greater evil as a result. ${ }^{899}$ Under this definition, the Federal trust obligation has become less concerned with the protection of tribal interests, and much more concerned with the administration of tribal affairs.

As Prof. Davies notes, under a libertarian framework for Indian rights, the goal for tribal advocates is to situate tribal interests within the republican framework of government such that tribes can exercise local government practices as free peoples exercising their right to self-

\footnotetext{
${ }^{896}$ Lincoln L. Davies, Skull Valley Crossroads: Reconciling Native Sovereignty and the Federal Trust, 68 Md. L. Rev. 290 (2009).

${ }^{897}$ For a useful summary see Kalt and Singer, "Myths and Realities of Tribal Sovereignty: The Law and Economics of Indian Self-Rule," Faculty Research Working Papers Series (Harvard U. Press Mar. 2004); available at http://www.nativeamericanlending.org/wp-content/uploads/2011/10/Myths-and-Realities-of-Tribal-Sovereignty.pdf (accessed Mar. 20, 2012).

${ }^{898}$ Hayek, supra n.397 at 11.

${ }^{899}$ Id. at $20-21$.
} 
government. This suggests a novel approach to tribal governance, and contemplates developing new tribal institutions that can handle a number of governmental administrative functions, including the development of policies and procedures for zoning, increasing law enforcement capabilities on the reservation, and processes for taxation, to name but a few of the many powers that tribes should expect to exercise over the reservation. ${ }^{900}$ The end goal would be the promotion of policies aimed at enabling tribes to develop "governance systems to better reflect [a tribe's] own local circumstances and tribal traditions," without the nagging concern of federal coercion in Indian affairs. ${ }^{901}$

\section{Questioning Federal Plenary Power}

Having re-evaluated the Marshall Model's trust doctrine, the next step in the analysis now turns to the potentially more controversial question of whether the Federal Government actually retains plenary power over Indian affairs at all under a libertarian framework for Indian rights. Given the framework's analysis of the trust doctrine it is, perhaps, not surprising that the libertarian framework for Indian rights wholly rejects the institution of plenary power as the philosophical antithesis of libertarian thought. Recall that John Locke described the institution of plenary power as one of despotical power, which rendered a nation's right to conquest by the same authority as an insufficient basis for "setting up any government." ${ }^{, 902}$ In fact, Locke compared the notion of governance by conquest to the validity of acquiring good tile by act of robbery. ${ }^{903}$

\footnotetext{
${ }^{900}$ Davies, supra n.896 at 369.

${ }^{901} \mathrm{Id}$.

${ }^{902}$ Locke, supra n.348 at 91.

${ }^{903}$ Id.
} 
As plenary power relates to the United States, Indian law scholar, Robert Clinton concludes that plenary power is fundamentally "at odds with America's first principles ${ }^{904}$ Clinton observes that where the institution has been challenged internationally, such decolonization efforts have resulted in "profound implications for redrawing of boundaries and spheres of legitimate governing power," except of course in America ${ }^{905}$ Given this international backdrop, Clinton concludes that the United States "cannot redress its racist history of colonialism in Indian country without confronting the Indian plenary power doctrine. ${ }^{" 906}$ Under Clinton's analysis, the resulting failure of the Federal Government to rethink its plenary power doctrine is nothing less than the delegitimation of all federal authority over Indian affairs. ${ }^{907}$ Regarding the U.S. Constitution, Clinton further argues that aside from its articulation in the Marshall Model, Congressional plenary power over Indian affairs has no textual basis in the Constitution itself, noting that the document constrains the scope of federal power to those powers enumerated under the Indian Commerce Clause. ${ }^{908}$

Under both the libertarian framework for Indian rights and under Prof. Clinton's unyielding international and constitutional critique, the doctrine of Congressional plenary power over Indian affairs is fundamentally at odds with modern conceptions of government, and the principle of government by consent of the governed. This suggests that the libertarian framework for Indian rights can be used to advocate the abandonment of the doctrine using the libertarian principles of freedom. Prof. Clinton outlines three major consequences of pursuing such a policy. First, he notes that an abrogation of plenary power over Indian affairs would limit federal legislative power over Indians to the Constitution's enumerated powers under the Indian

${ }_{904}^{904}$ Robert N. Clinton, There Is No Federal Supremacy Clause for Indian Tribes, 34 Ariz. St. L.J. 113, 162 (2002).

${ }^{905} I d$.

${ }^{906} \mathrm{Id}$. at 252.

${ }^{907} \mathrm{Id}$. at 253.

${ }^{908}$ Id. 
Commerce Clause. ${ }^{909}$ This suggests that Congressional power to legislate is limited to the regulation of the "the non-Indian side of the tribal federal relationship, not a power to regulate the Indians themselves. ${ }^{, 910}$ A second consequence Clinton identifies in abrogating plenary power over Indians affairs is that the Federal Government would be obliged to reconsider the supremacy of federal law over tribal law. ${ }^{911}$ Absent the doctrine of plenary power over Indian affairs, the Federal Government would no longer have a legal basis for asserting the largesse of federal power over Indians in court. The result would be a profound rethinking of the tribal/federal relationship, and the erstwhile precedents of the U.S. Supreme Court related to American Indians. ${ }^{912}$ One final consequence of abrogating plenary power over Indian affairs would be the inadvertent resuscitation of tribal/federal treaty making. ${ }^{913}$ Without the option of using Congressional plenary power to end treaty making with Indian tribes, the Federal Government would once again find itself in a position of seeking and negotiating tribal consent in its dealings with American Indians. ${ }^{914}$

Prof. Clinton's vision for the end of plenary power over Indian affairs is bold given the reluctance of the Supreme Court to revisit the matter, ${ }^{915}$ and unwillingness of Congress to limit its power on quite nearly any issue. But the benefit of Prof. Clinton's vision is that it provides insight into the consequences of reforming the doctrine, and a view of the challenges in abrogating plenary power over Indian affairs. Under a libertarian framework for Indian rights, Prof. Clinton's view could not be implemented wholesale because the application of the framework is incremental, one that seeks to advance policies promoting change toward the

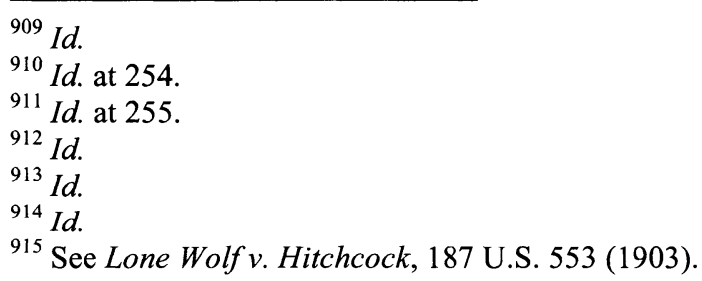


eventual abrogation of plenary power. ${ }^{916}$ Still, Prof. Clinton's vision provides an important set of guiding principles that can be incorporated into the libertarian framework for Indian rights in challenging the doctrine of Congressional plenary power over Indian affairs. ${ }^{917}$

\section{Unleashing the Market in Indian Country}

Thus far, I have explored ways to implement the libertarian framework for Indian rights in promoting the principles of limited government in Indian Country, and in promoting the realization of meaningful freedom in Indian affairs. The final principle of the framework to implement is the role of markets in promoting limited government and freedom in Indian Country. This section seeks to implement the market ideals of the libertarian framework for Indian rights in two ways: 1) the development of an Indian service-based economy, and 2) the acquisition of meaningful property rights in Indian Country.

\section{Developing an Indian Service-Based Economy}

One of the key insights of the libertarian framework for Indian rights is that markets help to secure freedom in Indian Country by providing economic opportunity. Economic opportunity, by extension, enables Indians to chart their own courses of action. Still, one of the nagging problems in Indian Country has been the abysmal rate of economic development on Indian reservations. ${ }^{918}$ As the University of Houston's Prof. Gavin Clarkson notes, many if not most Indian tribes have economies similar to those of "third world countries." ${ }^{\text {"919 }}$ While myths about Indian gaming dollars abound, Clarkson notes that gaming revenues do "not provide a significant economic stimulus for most tribal economies." ${ }^{, 920}$ In fact, a majority of federally-recognized

\footnotetext{
${ }^{916}$ Nozick, supra n.347 at 302.

${ }^{917}$ See Hayek, supra n.397 at 5 for a discussion of how libertarianism provides guiding criteria for the incremental promotion of liberty.

918 Gavin Clarkson, Accredited Indians: Increasing the Flow of Private Equity Into Indian Country as a Domestic Emerging Market, 80 U. Colo. L. Rev. 285 (2009) 
tribes do not have gaming operations, and of those tribes with Indian gaming operations, only a few generate significant income for tribal coffers. ${ }^{921}$ Given the unequal distribution of gaming revenues and the fact that small businesses drive much of the U.S. economy, ${ }^{922}$ the development of a service-based economy for the reservation is a crucial aspect of implementing the libertarian framework for Indian rights.

One key insight of Prof. Clarkson's research is that small businesses in Indian Country lack access to expansion capital, thereby limiting "their ability to grow and create jobs." ${ }^{\text {"923 }}$ One of the reasons that Indian small businesses lack access to capital is that the Federal Tax Code restricts tribes from issuing economic development bonds to small businesses. ${ }^{924}$ Whereas other governments may issue tax-exempt debt, tribal governments are able to issue such bonds only for "essential governmental functions." ${ }^{\text {" }}$ A second barrier to the development of the reservation economy is the inability for tribal members "to obtain debt financing for their entrepreneurial ventures. ${ }^{926}$ Simply put, banks are skeptical of investing in Indian Country out of fear that they will be unable to enforce the contracts made with Indian tribes and tribal members. ${ }^{927}$ One final barrier to the development of the reservation economy is the dearth of private equity available in Indian Country. ${ }^{928}$ According to Prof. Clarkson, Indian Country faces "at least a $\$ 10$ billion equity investment gap," and that when factoring in the size of Indian Country relative to the U.S., the gap in equity investment is actually on the order of $\$ 44$ billion. ${ }^{929}$ While Indian Country

\footnotetext{
${ }^{921} \mathrm{Id}$.

922 Id. at 287.

${ }_{923} \mathrm{Id}$.

924 Id. at 296-297.

${ }_{925} \mathrm{Id}$.

${ }_{926} I d$.

${ }^{927} \mathrm{Id}$.

${ }_{928} \mathrm{Id}$. at 298.

${ }^{929}$ Id. at 298-299.
} 
would seem ripe for private-equity investment, "most venture capitalists and angel investors are either unaware of or unwilling to travel to examine Indian Country venture opportunities."${ }^{, 930}$

Given these obstacles to the development of the service-based economy in Indian Country, Prof. Clarkson advocates solutions from the world of microfinance and private equity as a means of getting small businesses off the ground. ${ }^{931}$ Regarding microfinance in Indian Country, Prof. Clarkson cites examples from the Oglala Lakota Nation, Cheyenne River Indian Reservation, and the Wind River Indian Reservation as examples of successful microfinance stories through the development of community development financial institutions (CDFIs) that are funded under the Reigle Community Development and Regulatory Improvement Act of 1994. ${ }^{932}$ These community lending funds "promote economic revitalization and community development," through providing credit, capital, and financial services to underserved markets. ${ }^{933}$

While microfinance solutions have shown promise, they are limited in their ability to deliver expansion equity when companies are positioned to grow. ${ }^{934}$ Private equity would be a natural source for developing Indian businesses, but U.S. securities law do not include tribal governments as "accredited investors" from which venture capital and private-equity firms can raise funds for investment. ${ }^{935}$ The result is that Indian tribes are eliminated as funding sources, further hindering investment in Indian Country. ${ }^{936}$ Clarkson's solution to the problem is to reform U.S. securities law to include tribes under the safe harbor provisions of the statutes as accredited investors. $^{937}$

${ }^{930} I d$. at 299.

${ }^{931}$ Id. at 308-309.

${ }_{932} I d$.

${ }_{933}^{93} \mathrm{Id}$.

${ }^{934} I d$. at 313 .

${ }^{935}$ Id. at 317 .

${ }^{936} \mathrm{Id}$. at 319 .

${ }^{937}$ Id. 
While the preceding discussion of Prof. Clarkson's work delves a bit into the weeds of business development, such an exploration is important to the libertarian framework for Indian rights in that it outlines detailed steps for improving the productive powers of American Indian labor and suggests ways to jumpstart the service economy in Indian Country - all of which are consistent with libertarian ideals of market development. ${ }^{938}$ Specifically, Clarkson's work identifies two problems to attracting investment capital on the reservation (lack of access to startup capital, and lack of access to expansion capital), and then proposes institutional reforms that can aid in the development of a business-friendly climate on the reservation. As the libertarian framework for Indian rights suggests, such solutions promote the development of markets, lead to an increased quality of life on the reservation, and the realization of meaningful freedom in Indian Country through economic choice.

\section{Meaningful Property Rights in Indian Country}

Under the libertarian framework for Indian rights, in addition to building the reservation economy, the economic health of Indian Country is eminently dependent upon the development of meaningful property rights. But the problems of the extant Indian land tenure system are manifold. As Prof. EagleWoman notes in her article on tribalist economies, the General Allotment Act of 1887 divvied up the reservation land base into allotments for Indian heads of household. ${ }^{939}$ The remaining lands were declared to be surplus lands, and were summarily sold to non-Indian homesteaders. ${ }^{940}$ According to EagleWoman, when combined with the assimilation policy of the Federal Government, the Allotment Act systematically destroyed "the structure of tribal society, the prosperity of Tribal Nations, and tribal control over natural resources."

\footnotetext{
${ }^{938}$ See Smith, supra n. 477 at 9.

${ }^{939}$ EagleWoman, supra n.20 at 816.

${ }^{940}$ Id. at 817.

${ }^{941}$ Id. at $817-818$.
} 
The resulting patchwork of Indian land tenure created by the General Allotment Act has led to numerous inefficiencies in the management of Indian Lands. First, "lands within reservation boundaries must be placed in trust status with the U.S. government" in order for tribes to assume regulatory authority over the reservation. ${ }^{942}$ Under this trust status, the Federal Government maintains the deed to the allotments (and by default to legal title) of individual and/or tribal lands, with the caveat that these lands are not subject to state taxation. ${ }^{943}$ On the other hand, the result of Federal trust status is that landowners are not able to freely manage their lands so long as the Federal Government holds them in trust. ${ }^{944}$ But when lands that are owned by tribes and tribal members are not placed in trust status, they are considered taxable property by the states. ${ }^{945}$

While land has historically been the foundation for "capital asset creation" Indian trust lands are "inalienable and cannot be sold, taxed, mortgaged, or used for collateral." ${ }^{946}$ Naturally, such a system severely restricts economic development in Indian Country since the principle economic asset (land) is rendered powerless as an engine for economic growth. ${ }^{947}$ The result of the land tenure system is that much of Indian Country depends upon the welfare of the Federal Government in order to exist. The Bureau of Indian Affairs operates "a national tribal school system, a national law enforcement program within Indian Country, and a national reservation roads program. ${ }^{9948}$ Because Indian land assets cannot be effectively utilized, the cycle of dependency is perpetuated from generation to generation.

\footnotetext{
942 Id. at 819.

${ }_{943} \mathrm{Id}$.

944 Id.

${ }^{945} \mathrm{Id}$.

${ }_{946} \mathrm{Id}$.

${ }^{947}$ Id. at 820.

${ }^{948}$ Id.
} 
Under the libertarian framework for Indian rights, the land tenure system described above is at odds with basic libertarian notions of meaningful property rights. Meaningful property rights under the framework assume that lands can be put to productive and beneficial use, and that Indians and Indian tribes retain actual managerial authority and title over their property. Given the present system, it is necessary to rethink the Indian land tenure system in hopes of making it friendlier to tribes and tribal members.

One possible, incremental approach to the land tenure morass is H.R. 3532, The American Indian Empowerment Act of 2011. ${ }^{949}$ Under the proposed legislation, at the request of a tribe and subject to restrictions against alienation and taxation, the Secretary of the Interior would be authorized to convey to the tribe all "right, title, and interest held by the United States" in the lands requested, thereby converting tribal trust land into restricted fee tribal land. ${ }^{950}$ Under the bill, the restricted fee tribal land would retain its status as "Indian Country" for the purposes of all relevant statutes, ${ }^{951}$ and would also be exempt from the Secretary approval process currently required for tribal leases. ${ }^{952}$ Perhaps the most striking change to the Indian land tenure system under the proposed legislation would be the provision for tribal preemption over federal laws and regulations governing Indian land use. ${ }^{953}$ Under the legislation, tribes that enact tribal laws establishing a land tenure system governing the use of its lands "shall preempt any provision of Federal law or regulation governing the use of such lands." ${ }^{554}$ Interestingly, the law has already garnered a favorable reception from one of Indian Country's most prolific and controversial scholars ${ }^{955}$, Seneca Nation President Robert Odawi Porter. ${ }^{956}$ In his remarks before

\footnotetext{
${ }^{949}$ H.R. 3235, 112th Cong. (Nov. 30, 2011).

${ }^{950} \mathrm{Id}$. at $\S 2(\mathrm{a})$.

${ }^{951} \mathrm{Id}$. at $\S 2$ (b).

${ }^{952} \mathrm{Id}$. at $\S 2$ (c).

${ }^{953} \mathrm{Id}$. at $\$ 2(\mathrm{~d})$.

${ }^{954}$ Id.

${ }^{955}$ See supra n. 189.
} 
the House Subcommittee on Indian and Alaska Native Affairs, Porter noted that the legislation would "provide Indian tribal governments with greater control and flexibility over some or all of their lands," and would "eliminate the cumbersome and expensive federal review and approval process." 957 In addition, Porter cited the removal of obstacles to economic development that are apart of the current federal trusteeship, and allow tribes to exercise "territorial sovereignty over their own land." 958

Though the bill contains restraints on the alienation of Indian lands, under the libertarian framework for Indian rights the legislation marks a significant step along the incremental path toward meaningful property rights for American Indians. As Prof. EagleWoman noted in her work, the extant Indian land tenure system places a number of barriers in the way of economic development and utilization of Indian lands. The pending legislation would seek to rectify some of these obstacles by making it easier for tribes to manage and govern their own lands. Such an incremental response to the muddled Indian land tenure system is not only consistent with the libertarian framework for Indians rights, but might well be considered a hallmark of it.

\footnotetext{
${ }^{956}$ Robert Odawi Porter, Testimony Before the House Subcommittee on Indian and Alaska Native Affairs of the Committee on Natural Resources, United States House of Representations Legislative Hearing on H.R. 3532 The American Indian Empowerment Act of 2011, Feb. 7, 2012,

http://naturalresources.house.gov/UploadedFiles/PorterTestimony2.07.12.pdf (accessed Mar. 21, 2012).

957 Id.

${ }^{958} \mathrm{Id}$.
} 


\section{CONCLUSION}

\section{SOME THOUGHTS ON THE PATH FORWARD}

When we last discussed Taos, NM, we left the City of Taos and Taos Pueblo engaged in an ancient confrontation, each guarding a set of values and culture wholly foreign to the other. The evaluation of Federal Indian law and the legacy of the Marshall model underscore how complex the standoff truly is. Misguided legal opinions, assimilationist administrative decisions, coupled with wildly changing Congressional policies all indicate the crucial role that the Federal Government has played in the destruction of tribal institutions. The deconstructive tools of Critical Race Theory further demonstrate how the present system of Indian rights is fatally flawed and predisposed to promote the interests of governmental power structures at the expense of the tribes. Given the systemic problems of Federal Indian law, the need for a new framework of Indians rights seems, in the words of Thomas Jefferson, self-evident. The goal of this work has been to meet this need by deriving a framework for Indian rights out of libertarian philosophy that reflects the libertarian ideals of limited government, the maximization of liberty, and the promotion of markets in society.

Since most scholars engage in a bit of self-flagellation at the end of a work, it seems appropriate here to note a few things that this work does not address that should be addressed by future scholarship. First, the libertarian framework for Indian rights was discussed fundamentally 
in terms of the relationship between Indian tribes and the Federal Government. But the principles of the framework are not actually this limited. One area of future scholarship should include exploring how the principles of the libertarian framework for Indian rights might apply to the relationship between tribal members and their tribal governments. Such a project would have to take into account a great many factors specific to the tribal governments analyzed, including the history of the tribes in question, their traditional governing structures, the contemporary state of the tribe, and the relative strength of existing governmental institutions. A separate, companion work would also be needed to explore ways to implement the framework at the tribal policy level.

Another question this work did not address is how the libertarian framework for Indian rights applies to the principles and traditions of tribal customary law. An interesting application of this question would be to conduct an anthropological analysis of American Indian tribes to determine how elements of the libertarian framework for Indian rights might be manifested in traditional tribal cultures. Such an analysis would provide useful insights into the development of culturally appropriate governmental institutions and a better understanding of how to implement the principles of the framework at the tribal level. This would, of course, involve a heavy reliance upon fields outside of American Indian studies and Federal Indian law. Accordingly, it would be helpful for an inter-disciplinary team to tackle such questions of Indian law and anthropology.

Finally, this work did not evaluate in depth the relationship between the libertarian framework of Indians rights and the emerging model for international Indigenous human rights. There is much in the literature to suggest that the principles of libertarianism and the principles of international Indigenous human rights are complementary frameworks that can ably be used in 
tandem. Even as the principles of international Indigenous human rights law are beginning to be implemented at the state level (viz., the nation-state), it is likely that the arguments and ideals of one framework can be used to supplement the arguments of the other. Opportunities for collaboration and mutual implementation look to be quite abundant.

While the questions above remain unanswered, left for another day, the need for innovative solutions to Indian Country's policy dilemmas remains pressing. The libertarian framework for Indian rights is an attempt to meet this need, while challenging scholars to think about the problems of Indian Country in new ways. In contrast to Momaday's house made of dawn, while the issues confronting Indian tribes today are very old, they need not be everlasting. ${ }^{959}$

${ }^{959}$ N. Scott Momaday, House Made of Dawn, 1 (HarperCollins 1999). 